\title{
AVALIAÇÃO IN VITRO DA IIBERAÇÃO DE FLÚOR DE CIMENTOS DE IONÔMERO DE VIDRO FORRADORES E CIMENTANTES
}

\author{
RENATA BASTOS DEL'HOYO FERNANDES
}

\begin{abstract}
Dissertação apresentada à Faculdade de Odontologia de Bauru, da Universidade de São Paulo, como parte dos requisitos para a obtenção do grau de Mestre em Odontologia, área de Dentística.
\end{abstract}




\title{
AVALIAÇÃO IN VITRO DA LIBERAÇÃO DE FLÚOR DE CIMENTOS DE IONÔMERO DE VIDRO FORRADORES E CIMENTANTES
}

\author{
RENATA BASTOS DEL'HOYO FERNANDES
}

Dissertação apresentada à Faculdade de Odontologia de Bauru, da Universidade de São Paulo, como parte dos requisitos para a obtenção do grau de Mestre em odontologia, área de Dentística.

Orientadora:Profa Dra Maria Fidela de Lima Navarro 
1996

Fernandes, Renata Bastos Del'Hoyo

F391a Avaliação in vitro da liberação de flúor de cimentos de ionômero de vidro forradores e cimentantes / Renata Bastos Del'Hoyo Fernandes. -- Bauru, 1996.

122p. : il.; $29,7 \mathrm{~cm}$.

Dissertação. (Mestrado) -- Faculdade de Odontologia de Bauru. USP.

Orientadora: Profa Dra Maria Fidela de 
28 de Julho de 1968

MARÍ L I A - S P

$1986-1989$

$1991-1996$

$1993-1995$

Associações
Nascimento

Curso de Graduação em odontologia - Faculdade de odontologia de Bauru USP, Bauru, SP

Curso de Pós-Graduação em Dentística, ao nível de Mestrado - Faculdade de odontologia de Bauru USP, Bauru, SP

Professora Assistente do Departamento de Dentística da Faculdade de odontologia da UNIMAR, Marília, SP

APCD - Associação Paulislista de Cirurgiões Dentistas, regional de Bauru APG -FOB-USP - Associação dos Pós - Graduandos da FOB-USP

IADR - International Association for Dental Research 
"À força superior à qual cada um de nós, a sua maneira, se apoiou nos momentos mais difíceis e que nos permitiu chegar até aqui."

Marcelo 
Agradecimentos

Aos meus pais,

Manolo e Fernanda, agradeço o amor,

a amizade, o carinho e a dedicação sempre presentes. Os seus ensinamentos e exemplos de humildade, honestidade, paciência, confiança e determinação, por toda a vida, me acompanharão. Obrigada por serem os meus pais. Eu os amo muito. 
Ao meu irmão Marcelo, que sempre me acompanhou e torceu pelo meu sucesso e pela minha felicidade. Tê-lo como irmão, companheiro e amigo é uma grande honra e um grande privilégio.

Aos meus avós Urbano e Dulce, exemplos de luta e perseverança e motivos de grande orgulho. Poder desfrutar de suas companhias é sempre gratificante e compensador. Obrigado por tudo que sempre fizeram por mim. 
Ao meu companheiro, agradeço a paciência e a compreensão. Ao meu amigo, agradeço a lealdade, a confiança em mim depositada e - incentivo constante. Ao meu eterno namorado, agradeço o amor, o carinho e a dedicação

Ao meu marido Moacir, enfim, agradeço por você existir e estar ao meu lado.

À D.Ana, Cristina, José Roberto, José Ricardo, Ana Clara, César, André e Cláudia. Agora, eu faço parte também desta familia. A todos vocês agradeço a companhia acolhedora, a amizade e a atenção nunca ausentes. 
À Profa Dra Maria Fidela de Lima Navarro agradeço a atenção

e o respeito sempre presentes desde o início de nossa con-

vivência na época da Graduação. A sua paciência, seriedade,

honestidade, perseverança e dedicação sempre foram e serão exemplos para a minha vida profissional e humana. Tê-la como professora, orientadora, colega e amiga é uma grande e inigualável honra para mim. Muito obrigada, agora e sempre, por tudo.

Ao Prof. Dr. Ricardo Marins de Carvalho, mestre e amigo, agradeço a atenção presente em todo e qualquer momento.

Suas palavras de sabedoria, de companheirismo e de incentivo nunca me deixaram sem conforto ou sem resposta. Tenho certeza que sempre que eu precisar do mestre ou do amigo, você, mais uma vez e sempre, estará de plantão.

Ao Prof. Dr. Eduardo Batista Franco, cuja honestidade, seriedade e organização sempre me serviram de exemplo. obrigada pelos ensinamentos durante os Cursos de Graduação e Pós-Graduação e durante a convivência no PET . 
A minha amiga e companheira Raquel sano suga Terada.

Você foi, é e sempre será uma grande e verdadeira amiga e irmã. As nossas alegrias e tristezas, vitórias e fracassos, as nossas experiências e confidências, enfim, todos os momentos que passamos juntas representam muito para mim. Eu sempre estarei, embora longe, perto de você. Seja muito feliz e obrigada por sua amizade.

Aos colegas e amigos José Carlos Spadotto e Vera Maria de G. Castro spadotto, pessoas pelas quais tenho alta estima, agradeço a oportunidade de poder desfrutar da compania sempre fraterna e acolhedora. Os ensinamentos relacionados à profissão, os exemplos de amizade e a confiança em mim depositada eu jamais poderei esquecer. 
Agradeço de maneira especial

Aos demais docentes do Departamento de Dentística da $\mathrm{FOB}-$

USP, Profs. Drs. José Mondelli, Aquira

Ishikiriama,

João Lúcio Coradazi, José Carlos Pereira,

Carlos

Eduardo Francischone, Mário Honorato da Silva e Souza

Júnior e Rafael Francisco Lia Mondelli.

Cada um, a sua maneira, sempre contribuiu para a minha

formação como profissional e como pessoa.

Ao Prof. Dr. Eulázio Mikio Taga pela paciência, atenção e respeito que sempre dispensou a mim e à Raquel em nossa

convivência durante a realização deste trabalho.

Ao Prof. Dr. Eymar Sampaio Lopes pela realização da análise

estatistica deste trabalho e pela atenção que sempre me dispensou. 
Agradeço também

A todos os professores da FOB-USP que participaram e contribuíram de maneira fundamental para a minha formação.

\section{Aos funcionários dos Departamentos de}

Dentística e Bioquímica pela presteza

e cordialidade que sempre me

dispensaram.

Aos funcionários da Pós-Graduação e da Biblioteca pela boa vontade no atendimento e pelo respeito com que sempre me trataram.

Aos colegas do Curso de Mestrado, Laerte, Lauro,

Paulo Ricardo, Savério e Ricardo pela agradável

convivência. Agradeço de maneira especial às

colegas do Curso de Mestrado, Cecy,

Lucirene,

Maria Cecília, Maria Sílvia e Margarete pela

amizade e companheirismo. O que pudemos aprender

umas com as outras jamais iremos esquecer.

A todos que, de alguma forma, contribuíram

para a

finalização deste trabalho. 
À Faculdade de Odontologia de Bauru, através de seu Diretor Prof.Dr. Dagoberto sottovia Filho e do seu Vice-diretor Aymar Pavarini.

À Comissão dos Cursos de Pós-Graduação, através de seu Presidente Prof.Dr. José Carlos Pereira.

À CAPES e ao CNPq pela concessão da Bolsa de estudo durante a realização do Curso de Pós-Graduação. 


\section{Sumário}

Lista de figuras

Lista de tabelas

Resumo

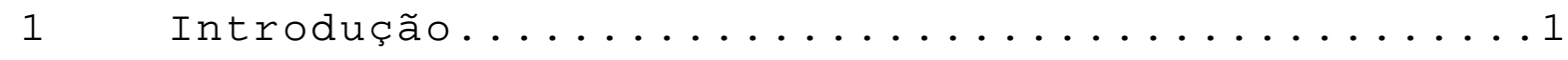

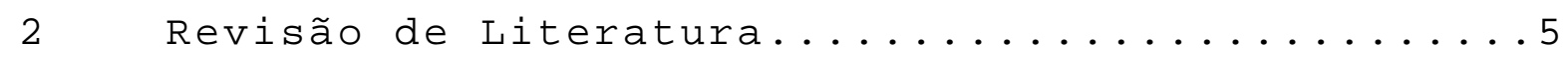

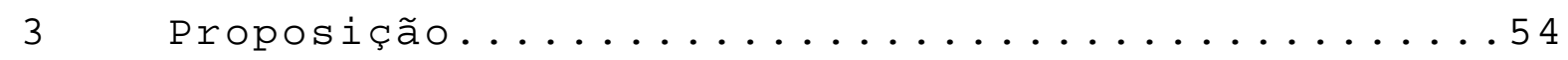

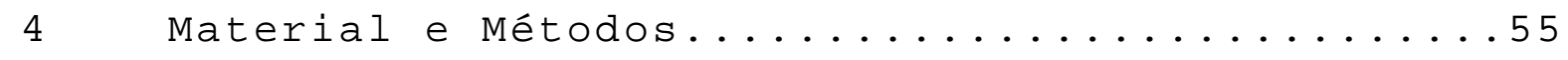

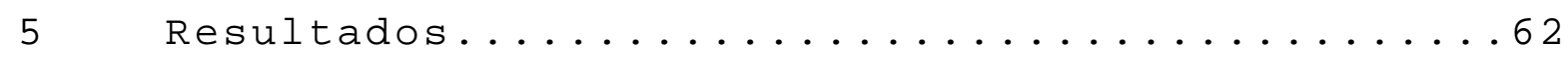

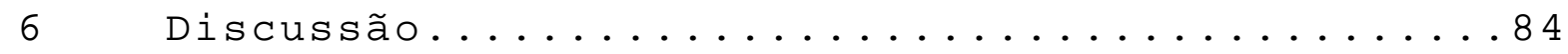

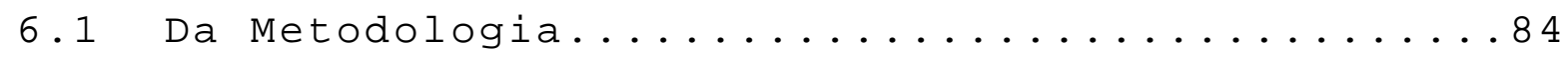

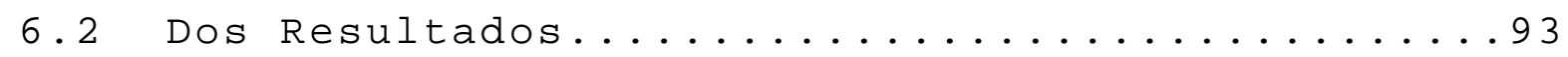

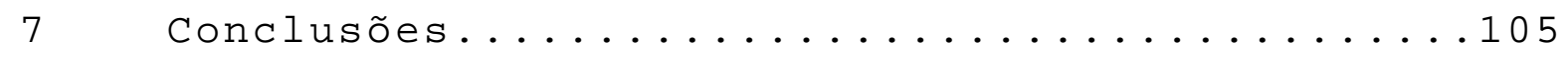

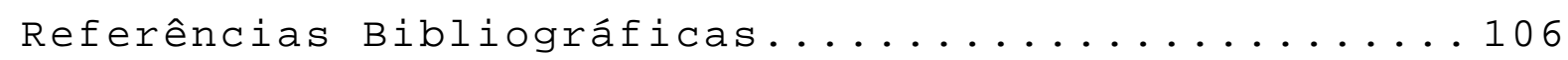

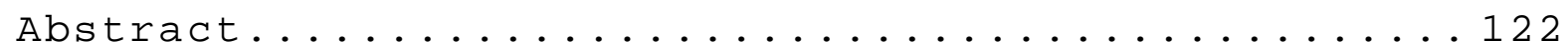

Apêndices 


\section{Lista de figuras}

Página

Figura 1 - Matriz de polietileno utilizada

para confeç̧ão dos corpos de prova:
A - Vista Lateral
B - Vista Superior.................57

Figura 2 - Corpo de prova suspenso em um recipiente plástico contendo o

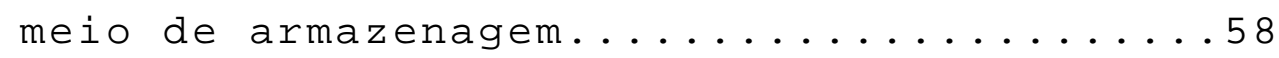

Figura 3 - Aparelho analisador de íons modelo SA-720:

A - eletrodo íon-específico modelo 94-09

B- eletrodo de referência modelo 90-01..61

Figura 4 - Médias e desvios padrão cumulativos da liberação de flúor dos cimentos de ionômero de vidro no período de leitura de 24 horas................68

Figura 5 - Médias e desvios padrão cumulativos da liberação de flúor dos cimentos de ionômero de vidro no período de leitura de 7 dias..................69

Figura 6 - Médias e desvios padrão cumulativos da liberação de flúor dos cimentos de ionômero de vidro no período de leitura de 28 dias.................70 


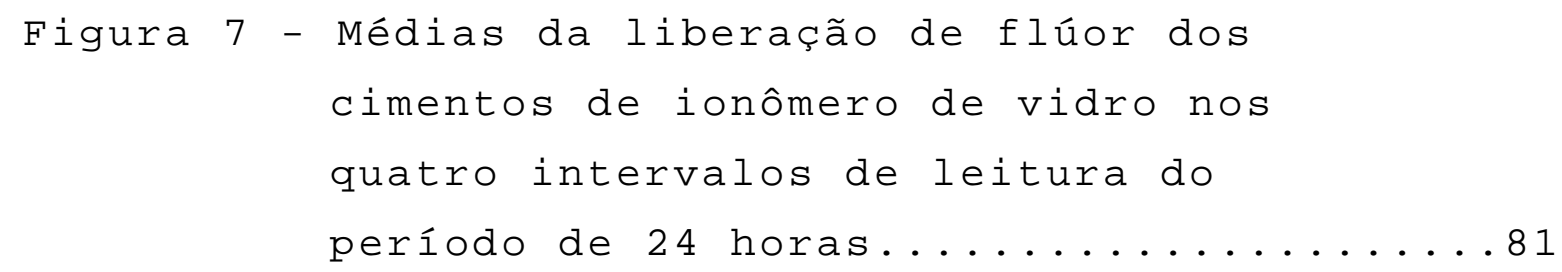

Figura 9 - Médias da liberação de flúor dos cimentos de ionômero de vidro nos quatro intervalos de leitura do

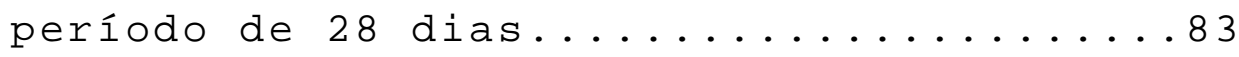




\section{Lista de tabelas}

Página

Tabela 1 - Análise comparativa da liberação

de flúor cumulativa entre os

materiais no período de 24 horas

(Tukey - Kramer) - valores em $\mu \mathrm{g} \mathrm{F}^{-} / \mathrm{mm}^{2} \ldots 63$

Tabela 2 - Análise comparativa da liberação

de flúor cumulativa entre os

materiais no período de 7 dias

(Tukey - Kramer) - valores em $\mu \mathrm{g} \mathrm{F}^{-} / \mathrm{mm}^{2} \ldots 64$

Tabela 3 - Análise comparativa da liberação

de flúor cumulativa entre os

materiais no período de 28 dias

(Tukey - Kramer) - valores em $\mu \mathrm{g} \mathrm{F}^{-} / \mathrm{mm}^{2} \ldots 65$

Tabela 4 - Análise comparativa da liberação

de flúor entre os materiais nos inter-

valos de leitura do período de

24 horas (Student - Newman - Keuls) -

valores em $\mu \mathrm{g} \mathrm{F}^{-} / \mathrm{mm}^{2} \ldots \ldots \ldots \ldots \ldots \ldots \ldots$

Tabela 5 - Análise comparativa da liberação

de flúor entre os materiais nos inter-

valos de leitura do período de

7 dias (student - Newman - Keuls) -

valores em $\mu \mathrm{g} \mathrm{F}^{-} / \mathrm{mm}^{2} \ldots \ldots \ldots \ldots \ldots \ldots \ldots$ 
Tabela 6 - Análise comparativa da liberação de flúor entre os materiais nos intervalos de leitura do período de 28 dias (Student - Newman - Keuls) valores em $\mu \mathrm{g} \mathrm{F}^{-} / \mathrm{mm}^{2} \ldots \ldots \ldots \ldots \ldots$ 


\section{Resumo}

o objetivo deste estudo in vitro foi avaliar e comparar o padrão e a quantidade de liberação de flúor de cimentos de ionômero de vidro forradores e cimentantes após períodos de 24 horas, 7 dias e 28 dias em água desionizada. Foram confeccionados 6 corpos de prova em forma de disco para cada material e cada período de leitura que, após a reação de endurecimento inicial, foram suspensos em recipientes plásticos contendo $18 \mathrm{~mL}$ de água desionizada. No momento da leitura, realizada a cada 6 horas no período de 24 horas, a cada 24 horas no período de 7 dias e a cada 7 dias no período de 28 dias, adicionou-se ao meio de armazenagem $2 \mathrm{~mL}$ de solução tampão TISAB III. A concentração de íons flúor em solução foi avaliada mediante leitura potenciométrica utilizando-se um aparelho analisador de íons. Vidrion $C$ e XR Ionomer apresentaram as maiores quantidades de liberação de flúor. Ketac-Bond, Vitrebond, Ketac-Cem, GC Fuji I e Shofu I ocuparam uma posição intermediária e o zionomer pó/líquido liberou a menor quantidade de flúor. Contudo, o padrão de liberação de flúor foi semelhante para todos os materiais testados. 


\section{1 - Introdução}

Um selamento marginal efetivo e permanente capaz de impedir a circulação de fluidos, bactérias, toxinas, íons e moléculas através da interface dente/restauração é uma propriedade altamente desejável para os materiais restauradores. Entretanto, a ausência desse selamento e a presença de um microespaço dinâmico, propiciando a microinfiltração marginal e, conseqüentemente, a reincidência de cárie e injúrias ao complexo dentino-pulpar, dão ênfase às propriedades cariostáticas e anticariogênicas dos materiais restauradores.

O flúor, desde a década de 40, tem se revelado como o principal elemento na prevenção da cárie dentária. Através de reações químicas entre o flúor e os tecidos mineralizados do dente, ocorre um aumento da resistência e uma diminuição da solubilidade do esmalte quando exposto a um ambiente ácido. Além disso, o flúor favorece a remineralização e, através de distintos mecanismos antibacterianos e antimetabólicos, reduz o potencial cariogênico das bactérias 46. Das vias de administração, o flúor empregado sistemicamente na fase pré-eruptiva dos dentes apresenta-se menos eficaz quando comparado ao flúor aplicado topicamente na fase pós-eruptiva, pois ocupa uma posição estática incorporado ao esmalte em concentração não significativa. o 
flúor dinamicamente importante é aquele presente constantemente na cavidade bucal durante as alterações de pH que ocorrem sobre a superfície dentária, agindo diretamente sobre os fenômenos de desmineralização e remineralização e inibindo o processo que conduz à cárie.

Por conseguinte, materiais restauradores, forradores e cimentantes que contenham flúor em sua composição poderiam representar, em potencial, fontes de liberação de flúor para o meio bucal.

A incidência significantemente menor de cárie secundária adjacente a restaurações de cimento de silicato, quando comparadas àquelas de outros materiais restauradores, pôde ser atribuída à gradual e contínua dissolução do material nos fluidos bucais, com conseqüente liberação de flúor ao longo da vida útil da restauração ${ }^{70}$ e absorção pela estrutura dentária adjacente ${ }^{52}$. A partir daí, o flúor passou a ser incorporado em uma grande variedade de materiais, tais como cimentos, amálgamas e resinas compostas

62

O cimento de ionômero de vidro, divulgado em 1971 por

WILSON \& Kent ${ }^{71}$, é um híbrido dos cimentos de silicato e de policarboxilato. Contendo flúor originalmente em sua composição, os cimentos de ionômero de vidro ganharam de imediato a atenção dos pesquisadores e clínicos devido, principalmente, às suas propriedades de adesividade à 
estrutura dentária e de liberação de flúor, conferindo-lhes características desejáveis de selamento marginal e potencial anticariogênico.

Um dos primeiros trabalhos sobre liberação de flúor dos cimentos de ionômero de vidro foi realizado por FORSTEN $^{17}$, em 1977, quando procurou comparar esta propriedade àquela de um cimento de silicato, obtendo resultados interessantes. Uma maior liberação de flúor foi associada ao cimento ionomérico, material menos solúvel, entretanto com maior quantidade de flúor em sua composição. A partir daí, foram realizados inúmeros trabalhos sobre a liberação de flúor de cimentos de ionômero de vidro utilizando-se, todavia, diferentes metodologias que permitem apenas comparações qualitativas entre os resultados.

Por apresentarem compatibilidade biológica com os tecidos pulpares, os cimentos de ionômero de vidro passaram a ser muito utilizados para forramento e base de cavidades, e como a microinfiltração marginal se constitui na maior causa de falhas clínicas na Dentística Restauradora, esses materiais tornam-se importantes, pois podem liberar flúor para as margens através da interface dente / restauração 25 e limitar a microinfiltração ${ }^{43}$.

As propriedades anticariogênicas dos agentes cimentantes também são de elevada importância, pois a 
reincidência de cárie é responsável pela maior porcentagem de insucessos $(36,8 \%)$ relacionados a coroas e próteses parciais fixas 55 e ainda, o acúmulo de placa circunjacente a acessórios ortodônticos fixos pode prontamente levar à desmineralização do esmalte.

Com o presente trabalho procurar-se-á avaliar e comparar a liberação de flúor de cimentos de ionômero de vidro forradores e cimentantes visando contribuir para a escolha clínica destes materiais. 


\section{2 - Revisão de Literatura}

Importantes informações foram dadas por VoLKER;

BEKARIS; MELILLO 68, em 1944, quando observaram uma redução na produção de ácidos por microorganismos em contato com restaurações de cimento de silicato. Uma observação mais importante, entretanto, foi a redução da solubilidade do esmalte, em ácido acético, quando banhado previamente em um extrato de cimento de silicato, sendo atribuída à reação superficial entre o flúor presente no material e o esmalte dentário. Tal fato poderia ocorrer durante a reação de endurecimento do cimento ou durante a sua dissolução nos fluidos bucais. Essa propriedade anticariogênica única inerente ao cimento de silicato poderia contribuir para a baixa incidência de cáries secundárias.

Em 1957, PHILLIPS; SWARTz 52 estudaram o efeito de certos materiais restauradores sobre a solubilidade do esmalte. Foram utilizados três cimentos de silicato, um deles não apresentando flúor em sua composição, cinco resinas acrílicas, quatro contendo fluoreto de sódio e / ou fluoreto estanhoso adicionados a variadas proporções, e três cimentos de fosfato de zinco, um deles contendo fluoreto de cálcio adicionado. Tanto esmalte pulverizado quanto superfícies de esmalte intactas foram empregados, sendo a solubilidade determinada através de medidas de cálcio e 
fósforo após tratamento do esmalte com ácido acético. Análises dos resultados revelaram que os cimentos de silicato proporcionaram uma considerável redução na solubilidade do esmalte, efeito comparável ao de aplicações tópicas de flúor, o que provavelmente aumenta a resistência e diminui a incidência de cáries secundárias. Todos os materiais que não continham flúor, na realidade, aumentaram a solubilidade das superfícies de esmalte intactas e aqueles aos quais o flúor foi adicionado reduziram a solubilidade do esmalte em variadas taxas, o que abriu um campo promissor para o desenvolvimento de materiais que poderiam apresentar propriedades anticariogênicas.

Conhecendo-se o processo de desintegração apresentado pelo cimento de silicato, acreditava-se que este material poderia representar um veículo ao qual o flúor seria adicionado e então, liberado vagarosamente e por um longo período de tempo no interior da cavidade bucal. Baseado neste pensamento, JINkS 34, em 1963, incorporou aproximadamente $15 \mathrm{mg}$ de silicofluoreto de sódio ao cimento de silicato Syntrex no momento da aglutinação. Realizando 394 restaurações tipo "túnel", sendo 350 na face distal de segundos molares decíduos e 44 entre molares decíduos, o autor procurou observar, principalmente, o efeito desse cimento fluoretado sobre a atividade de cáries interproximais na face mesial de primeiros molares 
permanentes recém-erupcionados. Após 6 anos de observação clínica e radiográfica, a alta porcentagem de sucesso (73\%), ou seja, primeiros molares permanentes que permaneceram livres de cáries interproximais enquanto uma cavidade desenvolveu-se nos dentes controles do quadrante oposto, sugeriu que um cimento fluoretado poderia interferir no aparecimento e na progressão da cárie dentária em superfícies proximais adjacentes. Em 7\% dos casos a lesão cariosa desenvolveu-se na face proximal do primeiro molar permanente apesar da presença do cimento fluoretado, todavia nos restantes 20\%, a lesão cariosa não se desenvolveu em qualquer dos quadrantes, o que sugere, segundo o autor, a migração de íons flúor a outras partes da cavidade bucal para imunização de todos os dentes.

FORSTEN; PAUNIO 21, em 1972, propuseram-se a estudar o conteúdo de flúor e a sua liberação de materiais virtualmente insolúveis no meio bucal. Das resinas acrílicas e compostas avaliadas, somente uma resina composta (TD 71) apresentava aproximadamente o mesmo conteúdo de flúor geralmente reportado para os cimentos de silicato. A resina composta Blendant, não apresentando flúor em sua composição e dois cimentos de silicato, Biocap e Vitacap, foram incluídos no estudo. Cinco corpos de prova foram confeccionados para cada material como descrito por FORSTEN; väLIAHO 23, em 1971, utilizando-se matrizes de aço medindo 
$2 \times 2 \times 12 \mathrm{~mm}$. Após 24 horas de armazenagem à temperatura ambiente, cada corpo de prova foi agitado por 7 dias em 10 $\mathrm{mL}$ de solução tampão fosfato $0,01 \mathrm{M}$, em $\mathrm{pH} 5,8$ e 6,8 , juntamente com 100 mg de hidroxiapatita sintética (HA). Após 7 dias, as soluções foram filtradas e a HA retida pelo filtro foi lavada três vezes com água destilada, sendo as análises de flúor realizadas de acordo com o método de difusão de Wharton ${ }^{69}$. Esse procedimento foi repetido a cada 7 dias durante 7 semanas, com as soluções renovadas a cada período de avaliação. Os resultados mostraram que, durante a primeira semana, a liberação inicial de flúor (absorção inicial pela $\mathrm{HA}$ ) foi maior para os cimentos de silicato quando comparados à resina composta. A partir da segunda semana, a liberação de flúor diminuiu lenta e gradualmente, sendo aproximadamente a mesma para os materiais testados. Com relação ao pH das soluções, pôde ser observado que a liberação durante a primeira semana foi maior na solução em pH 5,8. Novamente, a partir da segunda semana, diferenças não marcantes da liberação nas duas soluções puderam ser observadas. Pode ser que a liberação de flúor dos cimentos de silicato não seja dependente da dissolução do volume do material, mas sim governada pela solubilidade dos compostos contendo flúor e pela difusão dos íons flúor através do material. Isto poderia explicar também a liberação de flúor das resinas compostas virtualmente insolúveis. 
As propriedades do cimento de ionômero de vidro ASPA foram comparadas, in vitro, àquelas de outros tipos de cimentos comumente utilizados: cimento de silicato, policarboxilato, fosfato de zinco e cimentos de óxido de zinco e eugenol puro e modificado. Neste estudo realizado em 1973, KENT; LEWIS; WILSON 36 observaram que os valores de solubilidade e desintegração para o cimento ASPA foram levemente menores que aqueles para o cimento de silicato. Nos testes de erosão, O ASPA apresentou uma qualidade de superfície superior àquela do cimento de silicato, pois sua integridade superficial foi mantida frente ao ataque aquoso e de ácidos fracos. A explicação para estes resultados parece estar baseada nas ligações químicas presentes na matriz dos cimentos. No silicato são encontradas ligações iônicas, e quando os íons alumínio são substituídos por íons hidrogênio sob condições ácidas, ocorre fragmentação no interior da matriz. Já no cimento de ionômero de vidro estão presentes ligações covalentes, sendo que a substituição dos íons conduz apenas à redução das ligações cruzadas intercadeias, não ocorrendo fragmentação.

O propósito do estudo realizado por FORSTEN; PAUNIo ${ }^{22}$, em 1973, foi avaliar o efeito de um verniz protetor superficial sobre a liberação de flúor de um cimento de silicato. Também neste estudo, os autores avaliaram a liberação de flúor de materiais para forramento (Tubulitec e 
Cavisol) e de selantes de cicatrículas e fissuras (Epoxylite 9070 e Elmex Protector). Os resultados mostraram que duas camadas de verniz protetor superficial têm um efeito de redução definido somente sobre a liberação de flúor inicial do cimento de silicato, provavelmente não provocando quaisquer efeitos clínicos indesejáveis. O efeito prolongado do flúor nos materiais para forramento e nos selantes é duvidoso, pois somente uma liberação inicial (4 semanas) foi registrada.

CRISP; WILSON 7, em 1974, analisaram a decomposição do pó nos estágios iniciais da reação de endurecimento do cimento de ionômero de vidro ASPA I. A solução de ácido poliacrílico decompõe o pó e promove a liberação de íons e a formação de complexos. Uma interessante observação refere-se ao fato de que a liberação do flúor depende de sua condição molecular, devendo estar na forma cristalina, e mais ainda, que a formação de complexos de flúor representa um importante papel na transferência de espécies iônicas do pó e suas interações com o ácido poliacrílico.

Um estudo de três meses sobre a química da erosão em água de duas formas do cimento ASPA foi realizado, em 1976, por CRISP; LEWIS; WILSON 8. Os autores verificaram a liberação de sódio, cálcio, alumínio, flúor, sílica e fosfato, entretanto, observaram que o cimento de ionômero de vidro, diferentemente do cimento de silicato, não perde 
quantidades significantes de íons estruturalmente importantes e, conseqüentemente, apresenta uma matriz hidroliticamente mais estável. Com relação à proporção pó / líquido do cimento ASPA observaram que a liberação de íons, de uma maneira geral, aumenta conforme esta proporção diminui.

A liberação de flúor de um amálgama (Fluor Alloy) e de dois agentes cimentantes, um cimento de sílico-fosfato (Fluoro-Thin) e um cimento de policarboxilato (Poly-F) foi testada por FORSTEN 16 em 1976, seguindo a metodologia já descrita e utilizada por FORSTEN; PAUNIO ${ }^{21}$, onde a liberação de flúor é indicada pelo aumento do conteúdo de flúor da HA presente na solução de armazenagem. Para todos os materiais a liberação inicial de flúor (primeira semana) foi muito maior que durante as quatro semanas seguintes. Ao longo do experimento, os cimentos liberaram aproximadamente a mesma quantidade de flúor que os silicatos em estudo anterior 21, todavia, a liberação de flúor do amálgama foi mínima, indicando que o efeito terapêtico de uma restauração com este material pode ser comparado ao de uma única aplicação tópica de flúor.

o cimento de ionômero de vidro originalmente contém flúor em sua composição, mas a sua solubilidade nos fluidos bucais é menor que aquela do cimento de silicato, o que pode 
ter influência sobre a propriedade de liberação de flúor. Com base nisto, FORSTEN 17 realizou em 1977 um dos primeiros trabalhos sobre a liberação de flúor dos cimentos de ionômero de vidro, procurando comparar esta propriedade entre o ASPA e o Biocap, um cimento de silicato. O conteúdo de flúor do pó do cimento de silicato foi de 73,6 $\mu \mathrm{g} / \mathrm{mg}$ e do ionômero de vidro, $132 \mu \mathrm{g} / \mathrm{mg}$. A liberação de flúor de ambos os materiais foi muito maior durante as duas primeiras semanas, sendo que o cimento de ionômero de vidro liberou mais flúor que o silicato, com diferenças estatisticamente significantes durante a terceira, quarta e quinta semanas. Nesse trabalho, a maior liberação de flúor foi associada ao cimento ionomérico, material menos solúvel, entretanto com maior quantidade de flúor em sua composição.

O ionômero de vidro, pelo fato de ser um híbrido dos cimentos de silicato e de policarboxilato, possui certas características desejáveis de ambos os cimentos. Por conseguinte, MALDONADO; SWARTZ; PHILLIPS 42, em 1978, avaliaram a liberação de flúor e o efeito sobre o solubilidade do esmalte de um cimento de ionômero de vidro $(\mathrm{ASPA})$ e de um cimento de silicato (M.Q.). A adesividade do ASPA à estrutura dentária foi comparada àquela de um cimento de policarboxilato (Durelon). A quantidade e o padrão de liberação de flúor foram determinados utilizando-se sete 
corpos de prova em forma de disco de cada material, apresentando 9,5 mm de diâmetro e 2,5 mm de espessura. Estes corpos de prova foram suspensos em $3 \mathrm{~mL}$ de água destilada livre de flúor e a liberação foi medida através de eletrodos íon-sensitivos a cada 24 horas durante 21 dias. A solubilidade do esmalte, após 15 dias em contato com os cimentos, foi analisada por espectofotometria de absorção atômica do cálcio dissolvido após imersão, por 30 minutos, em $10 \mathrm{~mL}$ de solução de ácido acético em pH 4. O padrão de liberação de flúor foi similar para ambos os materiais, com os maiores valores registrados nos primeiros dias, os quais diminuíram e permaneceram a um nível constante até o final do experimento. Houve uma diferença altamente significante na quantidade total de flúor liberado entre os dois materiais, sendo de 1.800 Mg de flúor para o ionômero e de $710 \mu \mathrm{g}$ para o silicato. A solubilidade do esmalte em contato com o cimento ionomérico foi reduzida em 52\% e com relação ao silicato, a redução foi de 39\%. Os resultados indicam que o cimento de ionômero de vidro provavelmente é tão efetivo quanto o silicato na prevenção de cáries secundárias. O cimento ionomérico apresentou adesão ao esmalte e à dentina e, similarmente ao cimento de policarboxilato, a adesão ao esmalte foi mais forte que à dentina.

CAUSTON ${ }^{3}$, em 1981, relacionando as alterações nas propriedades físicas e mecânicas dos cimentos ionoméricos à 
exposição em água durante a reação de endurecimento, lançou dúvidas sobre a longevidade da liberação de flúor desses materiais. Após proporcionamento por peso dos componentes pó e líquido do cimento ASPA, foram confeccionados corpos de prova cilíndricos que permaneceram selados e armazenados em estufa a $37^{\circ} \mathrm{C}$ por 15 minutos, 1,24 e 48 horas a partir do início da aglutinação. Em seguida, os corpos de prova foram colocados em $10 \mathrm{~mL}$ de água destilada e, após períodos de imersão variados, as soluções foram renovadas e a liberação de flúor registrada por um fluorímetro até um período total de 6 meses. A liberação de flúor do cimento ASPA, afetada pela exposição em água durante a reação de endurecimento, cessou após os 6 meses de imersão, indicando que somente os íons flúor liberados no interior da matriz durante a reação de endurecimento estão disponíveis para proteção da estrutura dentária circunjacente.

Também em 1981, TVEIT; GJERDET 65 compararam a liberação de flúor de um cimento de silicato àquela de um cimento de ionômero de vidro e de um amálgama contendo flúor. Cinco corpos de prova de cada material foram confeccionados utilizando-se matrizes de Teflon, sendo em seguida armazenados por 1 hora a $37^{\circ} \mathrm{C}$ e a $100 \%$ de umidade relativa. Para uma maior padronização quanto à área do material exposta ao meio de armazenagem, os corpos de prova foram raspados com lixa de carboneto de silício n 320 . 
Posteriormente, passaram por uma limpeza ultra-sônica em água destilada por 1 minuto e, após serem pesados, foram colocados sobre um suporte de vidro e imersos em $50 \mathrm{~mL}$ de saliva artificial. Como a agitação ou renovação do meio de armazenagem poderiam afetar a taxa de dissolução, ele permaneceu inalterado durante 7 semanas. As medidas das concentrações de flúor na saliva artificial, expressas em $\mu \mathrm{g}$ $\mathrm{F}^{-} / \mathrm{mm}^{2}$, foram obtidas por espectofotometria. Pela análise dos resultados pôde-se observar que a liberação de flúor do

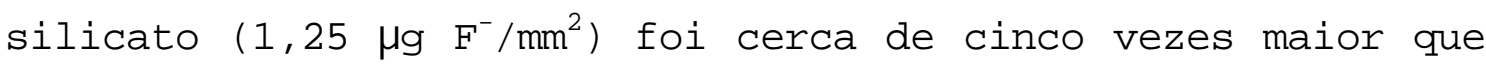

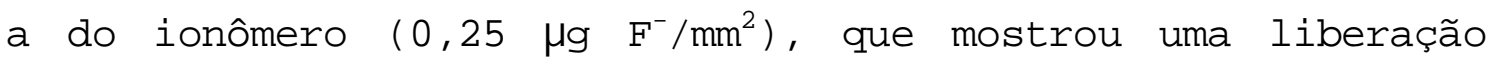
quatro vezes maior que a do amálgama $\left(0,06 \mu \mathrm{g} \mathrm{F}^{-} / \mathrm{mm}^{2}\right)$. Entretanto, a liberação de flúor relativa ao conteúdo de flúor original do material foi maior para o amálgama $(0,93 \%)$, seguido pelo silicato $(0,79 \%)$ e por último pelo ionômero $(0,12 \%)$.

A influência exercida pela proporção pó/líquido, temperatura e pH do meio de armazenagem e geometria do corpo de prova sobre a liberação de flúor do cimento de ionômero de vidro foi estudada por CRANFIELD; KUHN;WINTER ${ }^{\mathbf{5}}$, em um importante trabalho publicado em 1982. Utilizando-se o cimento ionomérico ASPA, os corpos de prova foram armazenados em água desionizada a $37^{\circ} \mathrm{C}, 29^{\circ} \mathrm{C}$ e $10^{\circ} \mathrm{C}$, não tendo sido verificada diferença estatisticamente significante na liberação. Quando testados corpos de prova 
manipulados a proporções pó/líquido de 2:1 e 3:1, a taxa de liberação de flúor após 28 dias foi significantemente maior com a proporção 2:1. Para investigar a influência do pH, os corpos de prova foram armazenados em soluções tamponadas em pH 4 e 9 e em água desionizada em pH 7. A maior liberação ocorreu em pH 4, seguido pelo pH 9 e 7. A influência exercida pela geometria do corpo de prova foi verificada utilizando-se matrizes de aço inoxidável em forma de tubo de mesmo diâmetro (15 mm) e variados comprimentos $(1,3,5$ e 10 mm), sendo a liberação de flúor medida enquanto os materiais encontravam-se nos tubos. A liberação foi diretamente proporcional ao comprimento do corpo de prova, levando os autores a concluírem que o flúor liberado é oriundo do volume total do cimento e não somente da área de superfície exposta.

DERKSON; POON; RICHARDSON 10 , em 1982, comparando a liberação de flúor do cimento ionomérico ASPA, do cimento de sílico-fosfato Petralit e deste último adicionado de silicofluoreto de sódio observaram, após 7 semanas, que o padrão de liberação de flúor foi similar para todas as amostras, sendo mais da metade do flúor liberado ao final da primeira semana. A cinética de liberação de flúor dos materiais seguiu uma descrição matemática, alterando-se como uma potência em função do tempo. 
Em um estudo in vitro de longa duração realizado em

1984 por SWARTZ; PHILIIPS; CLARK 60, avaliou-se a liberação de flúor de três cimentos de ionômero de vidro restauradores e três cimentantes, um cimento de silicato, um cimento de sílico-fosfato e um cimento de policarboxilato contendo fluoreto de estanho. Corpos de prova foram confeccionados a partir de matrizes de Teflon medindo $10,0 \mathrm{~mm}$ de diâmetro e 2,25 mm de espessura. Após o período de 1 hora em estufa a $37^{\circ} \mathrm{C}$, cada corpo de prova foi suspenso em um tubo contendo 3 mL de água destilada livre de flúor e, 24 horas mais tarde, foi lavado com $1 \mathrm{~mL}$ de água destilada e transferido a meio de armazenagem fresco. O conteúdo de flúor foi determinado por um eletrodo íon-específico da Orion, adicionando-se ao meio de armazenagem solução tampão TISAB (Total Ionic Strength Adjustment Buffer) para ajustar a força iônica. Este procedimento foi repetido por 30 dias e, nos próximos 11 meses, foi feita somente nos últimos 5 dias a leitura diária de cada mês. O padrão de liberação de flúor relacionado a todos os materiais testados foi similar, com maior liberação registrada nos períodos iniciais, declinando-se ao longo do tempo e com tendência a permanecer constante. O flúor esteve disponível nos cimentos ionoméricos durante um prolongado período de tempo, aproximadamente nas mesmas quantidades que nos cimentos de silicato, o que pode antecipar suas propriedades 
anticariogênicas. A quantidade de flúor liberada do cimento de sílico-fosfato foi significantemente menor que aquela dos cimentos ionoméricos, contudo, pouco efeito benéfico pode ser esperado do cimento de policarboxilato, pois a quantidade de flúor liberada deste cimento no décimo mês foi virtualmente zero.

Procurando aproximar-se da situação clínica MERYoN;

SMIтH 47, em 1984, utilizaram uma metodologia para testes de liberação de flúor baseada em um aparato que simulava um preparo cavitário. Três cimentos de ionômero de vidro (ASPA, Chemfil e ChemBond) e um cimento de policarboxilato (Poly-F Plus) contendo flúor adicionado foram inseridos, recém manipulados, nesses preparos cavitários que possuíam em suas bases filtros permeáveis e, em alguns casos, uma camada compacta de dentina pulverizada, simulando a situação clínica de dentina remanescente. O conjunto foi colocado sobre placas de petri contendo $4 \mathrm{~mL}$ de água destilada ficando, portanto, apenas uma superfície do material em contato com o meio de armazenagem, que permaneceu inalterado durante os períodos de leitura (1, 2, 4, 7 e 14 dias). Avaliando-se os resultados, a liberação não pareceu estar relacionada à proporção pó/ líquido nem ao conteúdo de flúor prontamente extraível dos materiais. Foram observadas diferenças estatisticamente significantes na liberação de flúor dos três cimentos ionoméricos, apesar da similaridade 
de composição química. Pode-se esperar que o ChemFil e o ASPA, materiais que liberaram flúor em maiores valores quando comparados ao ChemBond e Poly-F Plus, sejam tão efetivos quanto os cimentos de silicato na proteção contra cáries secundárias, entretanto, devido à alta liberação e penetração do flúor através da camada de dentina compacta, pode-se também esperar algum grau de inflamação pulpar.

A liberação de flúor, sódio e sílica do cimento de ionômero de vidro ChemBond durante aproximadamente 20 meses foi estudada por WILSON; GROFFMAN; KUHN 72 em 1985. Após proporcionamento por volume dos componentes pó e líquido do material, foram confeccionados corpos de prova em forma de disco e cilíndricos, com diferentes áreas, sendo suspensos em água destilada a $37^{\circ} \mathrm{C}$. As leituras foram realizadas inicialmente após períodos de armazenagem curtos e variáveis, que passaram a ser semanais até o final do experimento. Os corpos de prova em forma de disco, que apresentavam maior área de superfície que os cilíndricos, liberaram proporcionalmente maiores quantidades de flúor, sódio e sílica. A liberação destes elementos, presente após 20 meses, foi incongruente. Embora na composição química do material exista pequena quantidade de sódio $(1,3 \%)$ quando comparada àquela de flúor $(13,65 \%)$ e de sílica $(19,3 \%)$, a liberação de sódio foi cerca de duas vezes maior que a dos outros elementos. Desde que o sódio é o único cátion 
liberado em maiores valores, claramente a fim de preservar a eletroneutralidade quantidades equivalentes de flúor devem ser liberadas. Parece, portanto, que a liberação de sódio controla a do flúor.

Uma pesquisa interessante foi realizada por kUHN; WILsoN ${ }^{39}$, em 1985, a respeito do mecanismo de dissolução dos cimentos de silicato e de ionômero de vidro. Revisando sistemas análogos, tais como o tempo de liberação de drogas das cápsulas, decomposição de rochas e liberação de radioisótopos de matrizes vítreas, os autores propuseram um modelo teórico para descrever o mecanismo de dissolução como sendo um fenômeno baseado em três processos que ocorrem simultaneamente: 1) erosão de superfície; 2) dissolução oriunda das porosidades; 3) dissolução por difusão do corpo do material.

THORNTON; RETIEF; BRADLEY ${ }^{64}$, em 1986, propuseram-se a investigar e comparar a liberação de flúor e a resistência adesiva ao esmalte e à dentina de dois cimentos de ionômero de vidro restauradores, um convencional (Ketac-Fil) e o outro reforçado com partículas de prata (Ketac-Silver). A adição de prata ao cimento de ionômero de vidro reduziu a liberação de flúor e a resistência adesiva à dentina. A quantidade de flúor liberado do Ketac-Fil foi significantemente mais alta que a do Ketac-Silver, todavia, somente nos primeiros sete dias de leitura, pois nos 
seguintes sete dias não houve diferenças estatisticamente significantes entre os dois cimentos.

Com o intuito de esclarecer o mecanismo de erosão dos cimentos de ionômero de vidro, FUKAZAWA; MATSUYA; YAMANE 24 realizaram, em 1987, um valioso estudo onde armazenaram dois cimentos ionoméricos (Fuji Ionomer Type I e Ketac-Cem) em uma solução tampão ácida sob diversas condições e variáveis, analisando posteriormente a liberação de flúor, alumínio, silício e cálcio. As seguintes variáveis constaram do estudo: * tempo entre o início da mistura e a imersão na solução tampão (1 hora ou 24 horas); * armazenagem na solução tampão sem e com agitação; * solução de armazenagem mantida durante o período do estudo ou renovada a intervalos apropriados; * diferentes diâmetros do corpo de prova em forma de disco para a mesma espessura e diferentes espessuras para o mesmo diâmetro. Através das análises químicas realizadas na solução tampão de armazenagem os autores concluíram que as quantidades de flúor, alumínio, silício e cálcio liberadas dos cimentos foram diretamente proporcionais à raiz quadrada do tempo de imersão, sendo a taxa de dissolução controlada pela difusão dos íons na matriz do cimento, que foi influenciada pela estrutura da matriz e concentração de íons hidrogênio na superfície do cimento. As liberações não foram afetadas pela agitação da solução, não foram relacionadas à forma ou volume do corpo 
de prova e foram dependentes da área de superfície exposta. A liberação de flúor e silício foi pouco influenciada pela renovação da solução a intervalos apropriados e também, a dissolução dos corpos de prova imersos 24 horas após o início da mistura foi menor que daqueles imersos após 1 hora.

JONES et al. ${ }^{35}$, em 1987, compararam a liberação de flúor de 4 cimentos de ionômero de vidro cujos corpos de prova, em forma de disco, foram armazenados em água destilada a $37^{\circ} \mathrm{C}$ e $21^{\circ} \mathrm{C}$. A liberação de flúor foi significantemente influenciada pela temperatura, registrando-se maiores valores quando a solução de armazenagem manteve-se a $37^{\circ} \mathrm{C}$.

VALK; DAVIDSON 66, em um estudo laboratorial realizado em 1987, propuseram-se a investigar o efeito cariostático de um cimento de ionômero de vidro, comparando-o a uma resina composta, quando utilizados para cimentar bráquetes ortodônticos em uma série de amostras de dentes bovinos. Após a cimentação dos bráquetes, um tratamento desmineralizante foi realizado durante 3 semanas e a seguir, os dentes foram seccionados axialmente e examinados em um microscópio de luz polarizada. O cimento de ionômero de vidro protegeu o esmalte adjacente contra a desmineralização, efeito não observado com a resina composta. Os autores concluíram que a liberação de flúor do ionômero pode atuar como uma profilaxia passiva contra 
desmineralizações temporárias ou permanentes na superfície do esmalte.

\section{Em 1988 STANNARD; VIAzIS 58 avaliaram, através de} testes de solubilidade e de liberação de flúor, a interação de diferentes materiais restauradores e cimentantes com o esmalte de molares humanos extraídos submetido a condições desmineralizantes. Quarenta e dois molares previamente radiografados foram seccionados no sentido vestíbulo-lingual obtendo-se uma secção com $5 \mathrm{~mm}$ de espessura e, após a proteção das superfícies com um verniz ácido - resistente, dois preparos tipo caixa foram realizados nas faces vestibular e lingual de cada seção. O preparo mais cervical, em todos os casos, foi restaurado com amálgama e o mais oclusal, com um dos seguintes materiais: * Zinc cement (cimento de fosfato de zinco); * Tylok e HyBond (cimentos de policarboxilato); * Brilliant (resina composta); * Ketac-Fil (cimento ionomérico convencional) e* Ketac-Silver (cimento ionomérico reforçado). Após a reação de presa completa dos materiais, cada secção foi exposta a uma solução ácida desmineralizante, em $\mathrm{pH}$ 3, que foi renovada a intervalos de 24 horas durante 21 dias. As secções foram radiografadas diariamente para serem observadas alterações no tamanho da lesão e quantidade de material restaurador presente. A solubilidade dos materiais foi avaliada de acordo com a Especificação no 9 da American Dental Association. A 
liberação de flúor foi determinada em água destilada e solução desmineralizante a intervalos de 24 horas durante 7 dias, utilizando-se dois corpos de prova em forma de disco de cada material. Os valores de solubilidade e de liberação de flúor dos materiais foram maiores em solução desmineralizante que em água destilada. Observou-se uma solubilidade menor e mais lenta dos materiais restauradores (Brilliant, Ketac-Fil e Ketac-Silver) quando comparada àquela dos agentes cimentantes (Zinc cement, Tylok e HyBond). A maior taxa de liberação de flúor foi registrada para o Ketac-Fil. A resina composta Brilliant, apesar de apresentar $\bigcirc$ menor valor de solubilidade, propiciou 0 aparecimento de uma área de lesão consistentemente grande ao redor e subjacente à restauração. Comparando-se os resultados obtidos por todos os materiais, os cimentos de ionômero de vidro apresentaram uma interação positiva entre menor solubilidade, maior liberação de flúor e, conseqüentemente, maior proteção do esmalte contra a desmineralização .

Considerando a solubilidade e a liberação de flúor do cimento de ionômero de vidro como propriedades relacionadas e interdependentes, MUZYNSKI et al. 51, em 1988, procuraram mensurá-las através da imersão, em saliva artificial, de troquéis de gesso apresentando restaurações metálicas fundidas cimentadas com quatro diferentes ionômeros de 
vidro. As soluções de saliva artificial foram coletadas e substituídas a intervalos pré-determinados, sendo diluídas com tampão TISAB e analisadas através de um eletrodo específico para íon flúor que aferia, em milivolts, o potencial elétrico das soluções. A milivoltagem de cada amostra era, então, convertida à concentração de flúor em ppm. Os mais altos níveis de liberação de flúor, segundo os autores em decorrência da maior solubilidade dos materiais, foram registrados nas primeiras horas após imersão, alcançando um valor relativamente constante e significativamente menor. A maior liberação de flúor pôde ser relacionada aos cimentos com menores proporções pó/líquido (Everbond e Fuji Type I) quando comparados àqueles com maiores proporções (Biocem e Ketac-Cem) .

TAY; BRADEN 63, em 1988, falharam na tentativa de aplicar um modelo matemático para descrever o processo de liberação de flúor dos cimentos de ionômero de vidro. Através de um estudo in vitro, a liberação de flúor de alguns cimentos de ionômero de vidro foi monitorada por um período de 30 meses e, mediante os resultados, foi postulado que a liberação de flúor ocorreu através de dois processos de difusão distintos: um processo de difusão rápida da superfície e o outro, um processo de difusão lenta, gradual e contínua do corpo da amostra. Como a liberação nunca atingiu o patamar zero, ou seja, manteve-se a níveis 
detectáveis durante todo o experimento, a teoria clássica de difusão não pôde ser aplicada ao processo.

Ainda em 1988, SwIFT $\mathbf{6 1}$ avaliou o efeito do tempo de mistura sobre a liberação de flúor do cimento ionomérico, obtendo resultados significantemente maiores após um tempo de mistura curto (5 segundos) quando comparado a um tempo de mistura mais longo (10 segundos).

A liberação de flúor de três cimentos de ionômero de vidro, Vitrabond, Ketac-Fil e ChemFil II foi observada durante 6 semanas em um original estudo in vivo realizado por KOCH; HATIBOVIC - KOFMAN 37 em 1990. As unidades formadoras de colônia de Streptococcus mutans presentes na saliva antes e após a realização das restaurações com os cimentos ionoméricos também foram analisadas. Em trinta e seis crianças foram realizadas de 1 a 6 restaurações com um dos três materiais a serem testados. Saliva não estimulada foi coletada e analisada antes da realização das restaurações (concentração inicial), imediatamente, 3 e 6 semanas após o tratamento. A concentração inicial de flúor esteve entre 0,038 e 0,050 ppm. Imediatamente após a realização das restaurações, as concentrações de flúor elevaram-se a 0,8 ppm para o ChemFil II e a 1,2 ppm para o Ketac-Fil e Vitrabond. Após 3 semanas, as concentrações de flúor na saliva diminuíram cerca de 35\% para todos os materiais e após 6 semanas, as concentrações diminuíram mais 
$30 \%$ todavia nunca retornaram à concentração inicial. Uma relação diretamente proporcional pôde ser observada entre o número de superfícies dentárias restauradas e a concentração de flúor na saliva. A prevalência de Streptococcus mutans na saliva diminuiu após a realização das restaurações. Os autores concluíram que os elevados níveis de flúor durante todo o período de observação podem previnir a reincidência de cárie e remineralizar lesões cariosas iniciais, conferindo consideráveis propriedades anticariogênicas aos cimentos de ionômero de vidro.

Em um trabalho realizado em 1990 por EL MALLAKH; SARKAR

14, a liberação de flúor de quatro cimentos de ionômero de vidro, dois convencionais e dois reforçados com partículas de prata, foi comparada utilizando-se saliva artificial ou água desionizada como meios de armazenagem. As leituras foram realizadas diariamente durante o primeiro mês e, então, a cada dois dias até completarem-se dois meses, utilizando-se para isso um eletrodo específico para íon flúor. Para todos os materiais a liberação de flúor foi significantemente menor quando armazenados em saliva artificial. Os cimentos de ionômero de vidro convencionais liberaram mais flúor que os reforçados em ambos os meios, o que pode ser explicado pela substituição de 40 a $50 \%$ dos vidros contendo flúor pela prata. Segundo os autores, a liberação de flúor dos cimentos de ionômero de vidro em água 
desionizada não é representativa do processo de liberação in vivo, principalmente devido à complexidade do meio bucal

DESCHEPPER et al. 11, em 1990, propuseram-se a comparar - padrão e a quantidade de liberação de flúor de seis materiais fotoativados utilizados para forramento e base de cavidades, sendo duas resinas compostas e quatro ionômeros de vidro, após um período de 28 dias em saliva artificial (VA-Oralube). Corpos de prova cilíndricos, confeccionados a partir de moldes de politetrafluoretileno, foram fotoativados de acordo com as recomendações dos fabricantes, sendo armazenados em $1 \mathrm{~mL}$ de saliva artificial a $37^{\circ} \mathrm{C}$ por 24 horas. As transferências a meios de armazenagem frescos e as leituras da concentração de flúor em solução foram realizadas em intervalos de tempo pré-determinados, sendo de 1, 2, 4, 7, 14 e 28 dias a partir da manipulação do material. O padrão de liberação de flúor das resinas e dos cimentos de ionômero de vidro fotoativados foi similar ao padrão dos ionômeros convencionais, pois liberaram a maior proporção do flúor total cumulativo nas primeiras $24 / 48$ horas ocorrendo, a seguir, uma rápida queda na taxa de liberação. Reduções subseqüentes foram graduais para os intervalos de tempo remanescentes. Apesar de alguns materiais apresentarem maiores taxas de liberação, todas as bases fotoativadas testadas (Cavalite, Timeline, Vitrabond, XR Ionomer, Zionomer pasta/pasta e Zionomer pó/líquido) 
liberaram flúor, podendo ser benéficas à prevenção de cáries secundárias quando utilizadas sob restaurações. De acordo com os autores, a solubilidade, conteúdo de flúor, porosidade do material, natureza do meio de armazenagem (osmolaridade, pH, etc) e/ou alguns fatores desconhecidos podem, enfim, influenciar na quantidade de flúor liberado de um dado material.

Em 1990, MCCOURT; COOLEY; HUDDLESTON 40 avaliaram os níveis de liberação de flúor de um cimento de ionômero de vidro restaurador quimicamente ativado (controle) e dos mesmos materiais para forramento e base fotoativados testados no trabalho de DESCHEPPER et al. ${ }^{11}$. Após armazenagem em água destilada, as leituras de liberação de flúor foram feitas diariamente por 1 semana, semanalmente para as próximas 4 semanas e então, na 9a $13^{a}$ e $17^{a}$ semanas. Todos os materiais avaliados demonstraram um "burst effect" (efeito explosão), no qual a maior liberação de flúor foi observada nos dois primeiros dias de leitura, então diminuindo significantemente com o decorrer do tempo e com tendência à estabilização. A única exceção foi o material Cavalite que não apresentou liberação de flúor estatisticamente significante a partir da $5^{\mathrm{a}}$ semana de armazenagem. De acordo com os resultados obtidos pode-se prever que a liberação de flúor dos materiais utilizados para forramento e base é capaz de prevenir a formação de 
lesões de parede e também, a recorrência de cárie nas margens das restaurações.

CARVALHo et al. ${ }^{1}$, em um trabalho realizado em 1990, objetivaram avaliar o padrão de liberação de flúor de cimentos de ionômero de vidro e sílico-fosfato, disponíveis no mercado nacional brasileiro, em comparação a produtos que já apresentam essa propriedade comprovada e relatada na literatura. Os cimentos de ionômero de vidro testados foram Ceram Fil, Chelon-Fil e GC Fuji II, e os cimentos de sílicofosfato, Petralit e Kryptex. Foram confeccionados a partir de matrizes de Teflon 60 corpos de prova cilíndricos medindo $8,0 \mathrm{~mm}$ de diâmetro por $1,5 \mathrm{~mm}$ de espessura. A amostragem total foi dividida em 2 grupos de 30 que representaram os testes realizados em períodos de 24 horas e 7 dias. Os corpos de prova foram deixados em repouso por 20 minutos, em temperatura ambiente, antes de serem levados a recipientes plásticos contendo $18 \mathrm{~mL}$ de água destilada desionizada e identificados. Cada recipiente foi levado a um agitador e para o período de 24 horas, as leituras de liberação de flúor foram realizadas a cada 6 horas através da água contida no recipiente, à qual foram adicionados $2 \mathrm{~mL}$ da solução TISAB III. A água do recipiente era, então, renovada para as leituras posteriores. Para o período de 7 dias, as leituras foram feitas a cada 24 horas seguindo-se a mesma metodologia. Todas as leituras foram obtidas com um aparelho 
medidor de íon específico para fluoretos. Através dos resultados obtidos, pôde-se observar que todos os materiais testados apresentaram liberação de flúor, sendo esta marcantemente maior nos primeiros períodos após a mistura, decaindo acentuadamente a seguir e tendendo à estabilização com o passar do tempo em níveis baixos. O padrão de liberação de flúor descrito acima foi semelhante para todos os materiais e coerente com a literatura, entretanto a quantidade de flúor liberada foi heterogênea e isto provavelmente deve-se às diferentes porcentagens de fluoretos incorporadas aos materiais, bem como aos diferentes tempos de presa por eles apresentados.

Em um trabalho realizado por FORSTEN 18 em 1990, corpos de prova de oito cimentos de ionômero de vidro, sete utilizados para restauração e um para selamento de cicatrículas e fissuras, foram expostos à água corrente não fluoretada por 2 anos. Um amálgama e uma resina composta, ambos contendo flúor em sua composição, foram incluídos no trabalho para comparação. A liberação de flúor dos corpos de prova foi medida periodicamente após armazená-los, por 24 horas ou 1 semana, em $5 \mathrm{~mL}$ de água destilada desionizada (pH $6,1)$ ou em solução tampão de acetato de sódio em pH 5,0. Uma alta liberação inicial de flúor foi observada em todos os materiais testados, exceção feita à resina composta. A liberação de flúor dos cimentos de ionômero de vidro 
diminuiu com o tempo e um nível constante foi alcançado pela maioria dos produtos durante 0 período de 2 anos. A liberação foi maior quando os corpos de prova foram armazenados na solução em pH menor e, segundo a autora, devido a uma dissolução mais rápida do material. O amálgama e a resina composta liberaram quantidades mínimas de flúor quando comparados aos ionômeros de vidro.

HÖRSTED-BINDSLEV; I.ARSEN 31, em 1990, procuraram comparar a liberação de flúor entre dois cimentos ionoméricos restauradores convencionais e três reforçados com partículas de prata, sendo dois tipo cermet e um tipo "mistura milagrosa". Para isto, os materiais permaneceram armazenados em água destilada e após 15, 30 e 45 minutos, 24 horas e 100 dias, a liberação de flúor foi determinada por um eletrodo combinado. Altas concentrações de flúor (> 2 ppm) foram rapidamente determinadas nas soluções em contato com todos os cimentos, entretanto reduziram-se com o transcorrer do tempo. A mistura milagrosa, Fuji II + Lumialloy, e o Fuji II liberaram significantemente mais flúor que o Ketac-Silver, que por sua vez liberou significantemente mais flúor que o GC Fuji II e ChelonSilver. Os autores concluíram que fatores tais como composição química e manipulação, no que diz respeito ao proporcionamento e energia e tempo de mistura, influenciaram na real liberação de flúor do material. 
Testes laboratoriais realizados em 1990 por STRICKIAND;

RETIEF; RUSSELL ${ }^{59}$ avaliaram a resistência adesiva à dentina, através de cisalhamento, e também a liberação de flúor de cinco materiais utilizados para forramento e base, sendo três cimentos ionoméricos fotoativados (Vitrabond, Zionomer pó/líquido e zionomer pasta/pasta), um quimicamente ativado (GC Dentin Cement) e um material resinoso (Timeline). Os valores da resistência adesiva e da liberação de flúor do Vitrabond foram significantemente maiores que aqueles registrados para os outros produtos. A liberação de flúor de todos os materiais fotoativados testados seguiu o mesmo padrão apresentado pelo cimento ionomérico convencional, ou seja, diminuiu drasticamente após alguns dias e a seguir alcançou um platô, que foi mantido durante o período de 3 meses do estudo.

Em 1990, SHEN; BAN $^{57}$ realizaram um trabalho com o objetivo de investigar a influência da composição do pó dos cimentos de ionômero de vidro na liberação de flúor. Para tanto, foram preparadas nove composições diferentes fundindo-se proporções pré-determinadas de $\mathrm{S}_{1} \mathrm{O}_{2}, \mathrm{Al}_{2} \mathrm{O}_{3}, \mathrm{Ca} \mathrm{F}_{2}$, $\mathrm{Na}_{3} \mathrm{Al} \quad \mathrm{F}_{6}, \mathrm{Al} \mathrm{F}_{3}$ e $\mathrm{Al} \mathrm{PO}_{4}$. Para cada composição foram confeccionados 5 corpos de prova que, posteriormente, foram 
armazenados em 100\% de umidade durante 3 dias. Decorrido este período, os corpos de prova foram transferidos para um recipiente contendo $20 \mathrm{~mL}$ de água desionizada e mantidos a $37 \pm 1^{\circ} \mathrm{C}$ sendo $\circ$ meio de armazenagem trocado periodicamente durante 12 meses. A análise dos resultados indicou que as taxas de liberação de flúor dos cimentos de ionômero de vidro aumentaram com o conteúdo de sódio, mas diminuíram com o conteúdo de cálcio. Além disso, não foi observada nenhuma influência significante exercida pelo alumínio e fósforo. Portanto, os autores concluíram que altos conteúdos de flúor na composição do material não indicam necessariamente que a taxa de liberação de flúor será maior.

MARTINS 44, em 1991, propôs-se a quantificar a liberação de flúor, proveniente de restaurações oclusais, e sua incorporação ao esmalte de pré-molares extraídos em ciclos de desmineralização (Des) e remineralização (Re), utilizando para isto diferentes ionômeros de vidro e, como controle, o amálgama. O autor optou por dosar o flúor em soluções Des e Re na tentativa de simular, o mais próximo possível, as condições intra-bucais, respeitando os conceitos mais atuais do desenvolvimento da cárie dentária. Os resultados revelaram grande liberação de flúor durante as 
primeiras ciclagens, sendo maior durante os ciclos de Des em relação aos de Re, com tendência a diminuir e estabilizar-se em função do tempo e do tipo de material. O flúor liberado incorporou-se ao esmalte até a uma distância de aproximadamente 20 a $30 \mu \mathrm{m}$ da superfície e, assim, concluiuse que os cimentos de ionômero de vidro podem controlar o desenvolvimento de cárie secundária mesmo em condições de alto desafio cariogênico.

Utilizando metodologias de difusão em ágar e em caldo de cultura GARIB 26, em 1991, verificou que cimentos de ionômero de vidro restauradores, recém preparados e após a presa, apresentaram atividade antibacteriana sobre o Streptococcus mutans GS-5, bem como liberaram flúor em concentrações suficientes para inibir o crescimento e o metabolismo deste microorganismo. Todavia, não foi verificada correspondência entre 0 tamanho dos halos de inibição e as concentrações de flúor liberadas. Os cimentos foram capazes de inibir, por um período de até 96 horas, a fermentação de açúcares pelo Streptococcus mutans. Além disso, menos placa se depositou sobre os cimentos que sobre o controle positivo (Dycal fórmula avançada II).

A liberação de flúor in vivo e in vitro do Vitrebond, Ketac-Fil e ChemFil II foi investigada em 1991 por HATIBOVIC-KOFMAN; KOCH 27. Na primeira parte do trabalho, 
coletou-se saliva não estimulada de dezenove crianças 1 ano após a realização de restaurações com os cimentos acima mencionados. A concentração média de flúor variou entre 0,2 e 0,3 ppm, sendo cerca de 4 a 6 vezes mais alta que a concentração de flúor na saliva antes da realização das restaurações. Na segunda parte, cinco corpos de prova de cada material foram suspensos em água destilada. A concentração de flúor em solução foi medida 24 horas após a manipulação dos materiais, semanalmente durante 10 semanas e na décima primeira semana a concentração de flúor foi medida diariamente. No início da décima segunda semana, os corpos de prova foram imersos em $1 \mathrm{~g}$ de pasta dentifrícia misturado a $2 \mathrm{~mL}$ de água destilada durante 15 minutos, a seguir foram lavados e novamente suspensos em água destilada, sendo a concentração de flúor medida semanalmente por mais 5 semanas. Para os três materiais investigados a maior liberação de flúor foi registrada durante as primeiras 3 semanas e após a exposição à pasta dentifrícia. Os resultados do trabalho in vitro mostram, claramente, que os cimentos de ionômero de vidro são capazes de absorver o flúor em solução e posteriormente liberá-lo lentamente. Os resultados do trabalho in vivo podem ser explicados por esta capacidade importante de liberação - absorção - liberação de flúor, que eleva o nível deste elemento na cavidade bucal. 
Em um trabalho realizado em 1991 por FORSTEN 19, corpos de prova de cimentos de ionômero de vidro, que permaneceram em água corrente por 7 e 15 meses, foram expostos a uma solução a 50 ppm de flúor por 1 semana. Os corpos de prova expostos à solução liberaram posteriormente mais flúor que aqueles não expostos, todavia este efeito não foi observado em corpos de prova de resina composta utilizados para comparação. Na segunda parte do trabalho, observou-se que a liberação de flúor de corpos de prova recentemente preparados foi maior que aquela de corpos de prova deixados maturar por 3 dias. Na terceira e última parte do trabalho, corpos de prova permaneceram em água corrente durante 29 meses, sendo observada uma liberação de flúor a um nível constante após o período de 1 ano.

No mesmo ano, 1991, FORSTEN $\mathbf{2 0}^{2}$ realizou um trabalho com - objetivo de avaliar a liberação de flúor de cimentos de ionômero de vidro utilizados para forramento e base após exposição, por 24 horas e 6 meses, à água corrente. Os materiais apresentaram maior liberação de flúor inicialmente, entretanto valores importantes foram observados após 6 meses. Dois materiais, Zionomer e Cavalite, não liberaram flúor em quantidades consideráveis em ambos os períodos de avaliação, o que coloca em dúvida seu benefício clínico. 
Em 1991, GARCIA-GODOY; CHAN $\mathbf{2 5}$ realizaram um estudo in vitro avaliando a liberação de flúor de restaurações de amálgama que possuíam como material de base um cimento de ionômero de vidro. Preparos cavitários Classe V foram realizados nas faces vestibular e lingual de 50 molares humanos extraídos, aleatoriamente distribuídos em 5 grupos: Grupo 1= sem restauração; Grupo 2= restauração de amálgama; Grupo 3= igual ao Grupo 2 e, adicionalmente, $1 \mathrm{~mm}$ de KetacSilver sobre a parede axial; Grupo 4= GC Lining e amálgama e Grupo 5= Miracle Mix e amálgama. Após termociclagem, os dentes foram imersos em $4 \mathrm{~mL}$ de água desionizada e a liberação de flúor foi avaliada semanalmente durante 10 semanas, ao final de 1 ano e 24 horas após esta última leitura. Os grupos 4 e 5 apresentaram uma liberação de flúor significantemente maior que o grupo 3, todavia foi observada uma liberação comparável e constante a partir da sexta semana para os três grupos. Através dos resultados obtidos, pode-se prever que bases de ionômero de vidro liberem flúor às margens de um preparo cavitário, o que pode contribuir para a prevenção de cáries secundárias.

A liberação de flúor de um cimento de ionômero de vidro restaurador (Ketac-Fil) foi avaliada, durante um período de 8 dias, em uma pesquisa clínica realizada por HATTAB et al.29 em 1991. Aparelhos removíveis superiores em resina acrílica, contendo quatro espécimes do cimento, foram 
utilizados por quatro indivíduos adultos durante cerca de 8 horas à noite. Amostras de saliva total não estimulada foram coletadas antes dos indivíduos deitarem-se (amostras prétratamento) e pela manhã (amostras pós-tratamento). Observou-se um aumento estatisticamente significante na concentração de flúor salivar após o uso noturno dos aparelhos e também, uma taxa de liberação de flúor aproximadamente constante durante o período de testes.

Partindo do mesmo princípio de transformar-se um aparelho removível em fonte de liberação de flúor para o meio bucal, Cooley; MCcouRT 4 realizaram, em 1991, uma pesquisa laboratorial inserindo discos de XR Ionomer em materiais normalmente utilizados para a confecção desses aparelhos avaliando, a seguir, a liberação de flúor em água destilada diariamente durante a primeira semana, semanalmente para as próximas 4 semanas e ao final de 9 semanas. Registrou-se um "burst effect" (efeito explosão), onde a maior quantidade de flúor foi liberada no primeiro dia, diminuindo significantemente no segundo dia e tornandose relativamente estável após 7 dias e até o final do experimento.

Os valores de liberação de flúor in vitro do Vitrabond, um cimento de ionômero de vidro fotoativado, foram comparados aos resultados apresentados por três cimentos de ionômero de vidro convencionais, Ketac-Bond, GC Lining 
Cement e 3M Glass Ionomer Liner, em um interessante estudo realizado por MITRA 49 em 1991. Após um período de 2 anos, todos os materiais ainda apresentavam taxas de liberação de flúor em níveis comparáveis entre si. A quantidade cumulativa de flúor liberada foi linear e diretamente proporcional à raiz quadrada do tempo, e sendo assim, de acordo com HIGUCHI 30 , a liberação de flúor seria controlada pelo fenômeno da difusão. Neste estudo, MITRA 49 também avaliou outros aspectos e variáveis relacionados à liberação de flúor do Vitrabond. A taxa de liberação de íons flúor foi independente da variação do tempo de fotoativação do material. Uma mudança na proporção pó/líquido de 1,4:1 para 1,2:1 não afetou a taxa de liberação significantemente. A combinação de uma solução de ácido polialcenóico convencional com a porção pó do Vitrabond não alterou significantemente a liberação indicando, então, que a fotoativação não impede ou retarda a taxa de liberação de flúor no sistema. Estudos de espectometria de massa da dentina subjacente ao material fotoativado revelaram que houve uma considerável incorporação de íons flúor. Através de testes de resistência à compressão e à tração diametral, observou-se que não houve alteração significante nas propriedades mecânicas do material armazenado em água a $37^{\circ} \mathrm{C}$ por períodos prolongados ( 7 meses), indicando que a 
liberação de flúor não afetou adversamente a resistência do Vitrabond.

Em um estudo in vitro sobre cárie recorrente JENSEN;

WEFEL; HAMMESFAHR 33, em 1991, realizaram 70 preparos cavitários Classe $V$ padronizados na face vestibular de terceiros molares humanos extraídos, os quais foram divididos em 7 grupos e restaurados posteriormente com a resina composta Prisma-Fil. Em cada grupo foi utilizado um tipo de base intermediária diferente, cuja extensão sobre a parede gengival também apresentava-se variável. Sujeitos à termociclagem, os dentes foram em seguida armazenados em solução desmineralizante e agitados por 80 horas a temperatura ambiente. Após seccionamento vestíbulo-lingual, os dentes foram examinados ao microscópio de luz polarizada. Através da análise dos resultados, concluiu-se que a desmineralização da dentina ao longo da parede gengival em restaurações de resina composta Classe V pôde ser significantemente reduzida através do uso ou de base de cimento de ionômero de vidro (Ketac-Bond) ou de uma base de resina fotoativada que possui a propriedade de liberação de flúor (Timeline). Para se obter esse efeito protetor e preventivo, a base deve estender-se até o ângulo cavosuperficial promovendo, adicionalmente, a formação de uma "zona de inibição" à desmineralização próxima à restauração, 
indubitavelmente devido à liberação e difusão do flúor do material de base.

A maioria dos estudos tem avaliado a liberação de flúor dos cimentos de ionômero de vidro em água. Entretanto, a saliva contém cálcio, proteínas e íons fosfato e além disso, - pH da cavidade bucal está sujeito a variações de acordo com $\circ$ consumo de sacarose, 0 que pode influenciar na liberação de flúor dos ionômeros. A fim de aproximarem-se da situação in vivo, REZK-LEGA; ÖGAARD; RÖLIA 53 realizaram, em 1991, um estudo laboratorial avaliando a liberação de flúor de dois ionômeros de vidro cimentantes, Ketac-Cem e AquaCem, após 1 hora de armazenagem em água destilada em pH 7, em saliva humana não estimulada, em água pré-tratada com saliva em pH 7 e pH 4,5 e em albume e solução tampão fosfato em pH 7. A taxa de liberação de flúor em água destilada foi mais alta que em qualquer outra solução para ambos os cimentos. A presença de proteínas e fosfato na saliva reduziu a liberação de flúor, formando uma camada inibitória sobre as espécimes de ionômero de vidro. Esta hipótese é baseada na observação de uma taxa mais alta de liberação de flúor quando $\circ \mathrm{pH}$ da água foi reduzido para 4,5. A este nível de pH baixo, proteínas e fosfato estão desorganizados. 
HÖRSTED-BINDSLEV; IARSEN 32, em 1991, propuseram-se a avaliar a liberação de flúor de cinco materiais de base e forramento fotoativados. Um grupo de materiais (LCL 8, Ionoseal e Cavalite) é baseado em resinas fotoativadas contendo partículas de ionômero de vidro e substâncias adicionais, como hidróxido de cálcio ou hidroxiapatita. O outro grupo (XR Ionomer e Vitrabond) é constituído por cimentos de ionômero de vidro contendo grupos metacrilatos pendentes, hidroxietil-metacrilato (HEMA) ou uma mistura de ésteres de ácido metacrílico. A liberação de flúor dos materiais em água desionizada foi registrada por um eletrodo específico após os seguintes períodos de armazenagem: 15, 30 e 45 minutos, 24 horas e 100 e 200 dias. A liberação de flúor do XR Ionomer e Vitrabond foi significantemente maior em todos os períodos. A razão para a insignificante liberação de flúor do LCL 8, Ionoseal e Cavalite está no fato de que um cimento com íons lixiviáveis não é formado durante a reação de endurecimento. Portanto, a presença de partículas de ionômero de vidro em materiais de base e forramento fotoativados não é uma garantia para a liberação de flúor em concentrações terapêuticas.

Também em 1991, DESCHEPPER et al. 12 realizaram um estudo comparando a quantidade e o padrão de liberação de flúor, em saliva artificial e por um período de 84 dias, de 
onze cimentos de ionômero de vidro restauradores, forradores e cimentantes disponíveis comercialmente. Apesar da quantidade de flúor liberado por cada material ser diferente, o padrão de liberação de flúor foi virtualmente o mesmo para todos os materiais testados, registrando-se uma grande liberação nas primeiras 24 a 48 horas (27\% a 49\% dos totais cumulativos de flúor) seguida por um rápido declínio. Os resultados sugerem que a composição química dos materiais tem efeito sobre a quantidade de flúor liberado.

As taxas de liberação de flúor em saliva artificial durante 3 semanas de discos feitos de Miracle Mix, KetacSilver e Ketac-Bond foram determinadas por MCKNIGHT-HANES;

WHITFORD 41 em 1992. Como variáveis, em três discos de cada cimento de ionômero de vidro não se aplicou verniz protetor, em três aplicou-se o verniz e em outros três, além da aplicação do verniz, realizou-se o acabamento com pontas diamantadas. As maiores taxas de liberação foram relacionadas ao Miracle Mix, seguido pelo Ketac-Bond e Ketac-Silver, entretanto não foram proporcionais às concentrações de flúor presentes nos produtos. As taxas declinaram-se em função do tempo independentemente do produto ou tipo de tratamento. A aplicação de verniz causou uma redução de 61 a 76\% na liberação, dependendo do produto, e o acabamento dos discos envernizados produziu, com relação ao Miracle Mix, um aumento significante na 
liberação, não exercendo efeito sobre os outros dois materiais. Em um estudo adicional com o Miracle Mix, foi determinado que a taxa de liberação de flúor foi inversamente proporcional à relação pó/líquido utilizada no preparo dos discos.

Após um estudo laboratorial de 4 semanas, KOMATSU et al. 38, em 1992, não observaram uma relação direta entre o conteúdo de flúor presente no pó de onze cimentos de ionômero de vidro disponíveis comercialmente e a quantidade de flúor liberado destes materiais, em água destilada, após manipulação. Através dos resultados, os autores concluíram que o conteúdo de flúor inicial pode não ser o principal fator que interfere e/ou determina a taxa de liberação.

Em 1993 MEIRA 45 avaliou, in vitro, a capacidade de liberação de flúor de um cimento de ionômero de vidro para forramento (Vitrabond) sob restaurações de resina composta e amálgama. Preparos cavitários Classe V foram confeccionados nas superfícies vestibular e lingual de 25 dentes prémolares humanos hígidos extraídos. Os dentes, seccionados longitudinalmente, foram divididos em 5 grupos:- Grupo I (controle): restauração com Vitrabond; - Grupo II A: restauração com Vitrabond/adesivo/resina composta, estabelecendo-se margem gengival em esmalte; - Grupo II B: idem ao Grupo II A, estabelecendo-se margem gengival em cemento;-GrupoIII A: restauração com Vitrabond/ verniz/ 
amálgama, estabelecendo-se margem gengival em esmalte; Grupo III B: idem ao Grupo III A, estabelecendo-se margem gengival em cemento. Exceto o grupo controle, os demais foram submetidos à ciclagem térmica, sendo a liberação de flúor em água desionizada avaliada durante 96 horas. Todos os grupos apresentaram a capacidade de liberação de flúor e a somatória de todos os períodos, para cada grupo, apresentou diferenças estatisticamente significantes na seguinte ordem decrescente: Grupo controle > Grupo II A > Grupo II B > Grupo III A = Grupo III B.

Avaliando a liberação de flúor de corpos de prova de Ketac-Fil Aplicap protegidos com Ketac-Varnish, Visiobond ou Scotchbond II e sem proteção (controle), CASTRO et al. ${ }^{2}$, em 1993, observaram que os dois tipos de proteção superficial (verniz e adesivo) interferem negativamente sobre a taxa de liberação de flúor do cimento de ionômero de vidro, todavia os corpos de prova protegidos com verniz liberaram significantemente menos flúor que aqueles não protegidos ou protegidos com adesivo.

VERBEECK et al. 67, em 1993, procuraram investigar se a variabilidade nos valores de liberação de flúor poderia ser reduzida pelo uso de um sistema capsulado, quando comparado a um sistema de proporcionamento e mistura manuais, ambos baseados na mesma formulação qualitativa e quantitativa do cimento de ionômero de vidro Fuji II. Cinco operadores, 
independentemente, prepararam 5 discos de cada tipo de cimento (Fuji II e Fuji Cap II), sendo determinada a liberação de flúor em água destilada e desionizada durante 14 dias. Os valores de liberação de flúor do Fuji Cap II foram significantemente maiores que aqueles do Fuji II, porém em ambos os sistemas observou-se variabilidade de resultados. Então, o processo de proporcionamento e/ou mistura dos constituintes do cimento de ionômero de vidro contribuiu para a variabilidade dos valores de liberação de flúor independentemente do sistema considerado.

A liberação de flúor, sódio, silício, cálcio, estrôncio e alumínio de cimentos de ionômero de vidro fotoativados foi avaliada por Forss 15, em 1993. Um cimento ionomérico convencional e um reforçado com partículas de prata foram utilizados como controle. Durante o período de armazenagem de 122 dias em água desionizada e em ácido lático 0,01 mol/L (pH 4,0), os materiais apresentaram considerável variação na liberação de todos os elementos. Pôde-se observar que o padrão de liberação de sódio foi similar àquele do flúor, com uma alta concentração inicial seguida por uma concentração mais baixa, porém contínua. A liberação de flúor elevou-se durante a imersão em ácido lático e a liberação de silício, diferentemente, apresentou-se constante durante todo o período de avaliação. Em ácido lático, registrou-se uma maior liberação dos cátions 
formadores da matriz (alumínio e cálcio ou estrôncio), o que sugere que os cimentos ionoméricos fotoativados, igualmente aos quimicamente ativados, são susceptíveis à erosão.

Em um estudo laboratorial realizado em 1993 por SEPP̈̈;

FORSS; ÖGAARD 56, quinze amostras recém preparadas e trinta maturadas em água destilada, durante 14 dias, de Ketac-Fil e Ketac-Silver foram cobertas por uma camada de células de Streptococcus mutans. Após um período de incubação de 20 horas em uma solução de sacarose 1,7\%, foram realizadas avaliações, entre outras, do $\mathrm{pH}$ e do conteúdo de flúor na fase fluida e nas células. Após lavagem, 15 amostras maturadas foram expostas à pasta dentifrícia Colgate Fluor e as outras 15, ao flúor gel Elmex, sendo realizados a seguir os passos anteriormente descritos. A exposição à pasta dentifrícia resultou em um pequeno aumento na liberação de flúor e em leve efeito inibitório sobre as bactérias, este último detectado pela diminuição na queda do pH. Após exposição ao flúor gel, o conteúdo de flúor na fase fluida e nas células apresentou-se tão alto quanto nas amostras recém preparadas, e o efeito inibitório sobre a queda do pH e metabolismo de eletrólitos apresentou-se até mais pronunciado. 
MOMOI; MCCABE 50, através de um estudo laboratorial realizado em 1993, observaram que cimentos de ionômero de vidro fotoativados apresentaram um potencial de liberação de flúor, em água destilada e por um período de 3 meses, equivalente àquele de cimentos de ionômero de vidro convencionais. A quantidade de flúor liberado variou entre os materiais testados, o que pode ser decorrente da formação de compostos de flúor e sua interação com o ácido poliacrílico e ainda, no caso dos ionômeros fotoativados, do tipo e quantidade de resina utilizada para a reação de endurecimento fotoquímica.

Em uma pesquisa realizada em 1994, CREANOR et al. 6 analisaram as características de liberação e absorção de flúor de cinco cimentos de ionômero de vidro disponíveis comercialmente (Ketac-Fil, ChemFil superior, Fuji II LC, Aquacem e Vitrebond). A liberação de flúor foi analisada em água desionizada e por um período de 60 dias. Em seguida, após exposição dos corpos de prova a uma solução de flúor a 1.000 ppm por 2 minutos diariamente, a absorção e posterior liberação de flúor dos materiais foi analisada, em água desionizada, por um período de 20 dias. Todos os materiais liberaram quantidades mensuráveis de flúor durante o período de observação de 60 dias. Após exposição à solução de flúor, todos os corpos de prova liberaram consistentemente mais 
flúor que aqueles que permaneceram em água desionizada como controle. Este processo dinâmico de absorção e liberação foi mantido durante todo o período experimental e sugere implicações clínicas significantes.

\section{HATIBOVIC-KOFMAN; KOCH; EKSTRAND ${ }^{28}$, em 1994, realizaram} um trabalho com a finalidade de avaliar a liberação de flúor e a capacidade de reabsorver o flúor de cinco cimentos de ionômero de vidro, nominalmente XR Ionomer, Vitrebond, Fuji Lining, Baseline e Zionomer. Quinze corpos de prova de cada material foram suspensos em água desionizada, sendo a liberação de flúor avaliada diariamente durante 11 dias. Em seguida, os corpos de prova foram expostos a soluções de fluoreto de sódio a 0,02, 0,04 e 0,2\%, durante 2 minutos, nos dias 12, 17, 22 e 27, e a liberação foi avaliada diariamente até $\circ 32^{\circ}$ dia. Todos os materiais apresentaram a capacidade de reabsorver o flúor frente às repetidas exposições às soluções de fluoreto de sódio. Os resultados indicam que os cimentos de ionômero de vidro funcionam como um reservatório de flúor, podendo atuar como um sistema de liberação deste elemento de forma gradual e prolongada.

Através de uma pesquisa laboratorial realizada em 1995, WOOLFORD; GRIEVE 73 avaliaram o efeito da aplicação de calor radiante sobre a liberação de flúor de um cimento ionomérico. O calor radiante foi aplicado em diferentes intensidades e por diferentes intervalos de tempo 
utilizando-se uma fonte de luz halógena de alta intensidade. A liberação de flúor em água desionizada foi avaliada por um período de tempo de 2 anos. A aplicação de calor radiante não exerceu um efeito estatisticamente significante sobre a liberação de flúor do material, entretanto os resultados revelaram que a liberação de flúor foi reduzida pela aplicação do calor radiante.

Objetivando esclarecer a relação entre a composição do pó e a liberação de flúor dos cimentos de ionômero de vidro DEVLIN et al. 13, em 1995, utilizaram duas séries de vidros produzidas e avaliaram a liberação de flúor e de outros íons em água estéril de alta pureza. Observou-se uma forte correlação entre a liberação de flúor e o conteúdo de flúor e sódio na composição dos vidros. O processo de liberação parece ocorrer predominantemente através de um mecanismo de troca de íons, mecanismo este facilitado pela presença de íons sódio, possivelmente pelo rompimento da matriz do cimento e aumento da mobilidade dos íons.

Com a realização de uma pesquisa in vitro utilizando vidros modelos com conteúdo variável de flúor e metal alcalino DE BARRA et al.9, em 1995, concluíram que o principal mecanismo de liberação de flúor para todos os cimentos de ionômero de vidro testados não foi o de íons opostos, como postulado na literatura ${ }^{\mathbf{7 2}}$, mas sim um 
mecanismo de troca de íons onde um íon flúor do cimento é trocado por um grupo hidroxila da água do meio em contato.

RYU; LEE; $\mathbf{K I M}^{\mathbf{5 4}}$, em 1995, avaliando a liberação de flúor de cimentos de ionômero de vidro restauradores em água desionizada e saliva artificial, obtiveram menores valores para os corpos de prova armazenados em saliva artificial, entretanto este resultado não foi apresentado por todos os materiais testados, pois não houve diferença estatisticamente significante entre os dois meios de armazenagem para certas marcas comerciais.

Entre os fatores que podem afetar a taxa de liberação de flúor dos cimentos de ionômero de vidro destaca-se particularmente a manipulação, pois pode ser controlada pelo clínico. Baseados nisto, MILLER et al.48, em 1995, realizaram um estudo com o objetivo de determinar a taxa de liberação de flúor de seis cimentos de ionômero de vidro, sendo três capsulados e manipulados mecanicamente (Miracle Mix, Ketac-Silver e Fuji Cap II) e três não capsulados e manipulados manualmente (Miracle Mix, Chelon-Silver e Fuji Ionomer Type II). Para garantir a similaridade de composição, as proporções pó/líquido dos ionômeros manipulados manualmente foram as mesmas que a dos seus respectivos manipulados mecanicamente. O tempo de trituração variou entre 5, 10 e 15 segundos. A liberação de flúor foi determinada após os corpos de prova permanecerem por 1, 2, 
3, 7, 14, 21 e 28 dias em água destilada desionizada, utilizando-se para isto um eletrodo íon-seletivo e solução tampão TISAB II. Pela análise dos resultados, não houve diferença significante na taxa de liberação de flúor entre os três diferentes tempos de trituração para os três materiais testados durante o período do estudo, entretanto, a liberação de flúor cumulativa dos materiais manipulados mecanicamente foi significantemente maior que a dos materiais manipulados manualmente. Uma possível explicação para este fato é que a manipulação mecânica pode aumentar a reação entre as partículas de vidro e o líquido do cimento, conseqüentemente aumentando $\circ$ volume da fração de matriz e diminuindo o da fração de partículas não reagidas, o que tende a aumentar a taxa de liberação de flúor. 
3 - Proposição

o objetivo deste estudo in vitro foi avaliar e comparar - padrão e a quantidade de liberação de flúor de cimentos de ionômero de vidro forradores e cimentantes após períodos de 24 horas, 7 dias e 28 dias em água desionizada. 


\section{4 - Material e Métodos}

Os cimentos de ionômero de vidro selecionados, quatro do tipo I, utilizados para cimentação, e quatro do tipo III, utilizados para forramento e base, estão listados no quadro I.

Quadro I - Cimentos de ionômero de vidro selecionados

\begin{tabular}{|l|l|l|l|l|}
\hline MATERIAL & ABREVIATURA & FABRICANTE & TIPO & ATIVAÇÃO \\
\hline Ketac-Cem & KC & ESPE & I & química \\
\hline GC Fuji I & FJ & GC Dental Ind.Corp. & I & química \\
\hline Shofu I & SH & Shofu Dental Corp. & I & química \\
\hline Vidrion C & VC & S.S.White & I & química \\
\hline Ketac-Bond & KB & ESPE & III & química \\
\hline Vitrebond & VB & 3M & III & luz \\
\hline XR Ionomer & XR & Kerr & III & luz \\
\hline Zionomer pó/líq. & ZI & Den-Mat Corp. & III & luz \\
\hline
\end{tabular}

A manipulação dos materiais foi efetuada em ambiente refrigerado à temperatura de $23 \pm 2^{\circ} \mathrm{C}$.

o proporcionamento dos componentes pó e líquido foi realizado por volume, seguindo-se as recomendações dos fabricantes. Para os cimentos do tipo III foi utilizada a proporção pó/líquido recomendada para forramento. Os corpos de prova foram confeccionados a partir de matrizes de polietileno que possuíam, em sua parte central, um orifício circular ao qual encaixava-se um êmbolo de mesmo diâmetro e menor espessura (figura 1), permitindo a obtenção de corpos de prova em forma de disco apresentando $8,0 \mathrm{~mm}$ de diâmetro e 
1,5 mm de espessura. Após a aglutinação realizada com uma espátula de ágata sobre placa de vidro resfriada, os materiais foram inseridos no interior das matrizes com auxílio de uma seringa Centrix (DFL Ind. e Com. Ltda), procurando-se evitar a incorporação de bolhas.

Após total preenchimento, uma tira de poliéster foi posicionada sobre a matriz e, com uma placa de vidro, realizou-se pressão manual durante 30 segundos para permitir - escoamento dos excessos do material. Nesta etapa, os cimentos de ionômero de vidro Vitrebond, XR Ionomer e Zionomer pó/líquido foram fotoativados, por 40 segundos, com um aparelho fotopolimerizador Heliomat (Ivoclar - Vivadent).

Os corpos de prova foram mantidos em repouso, protegidos com a tira de poliéster durante 20 minutos à temperatura ambiente, sendo posteriormente removidos da matriz, através do êmbolo, e perfurados em sua parte central com uma ponta diamantada n 1011 da KG Sorensen girando em alta velocidade sem refrigeração.

A seguir foram suspensos, através de um fio de seda, em recipientes plásticos contendo $18 \mathrm{~mL}$ de água desionizada. É importante ressaltar que os corpos de prova permaneceram suspensos sem entrar em contato com as paredes do recipiente (figura 2). 


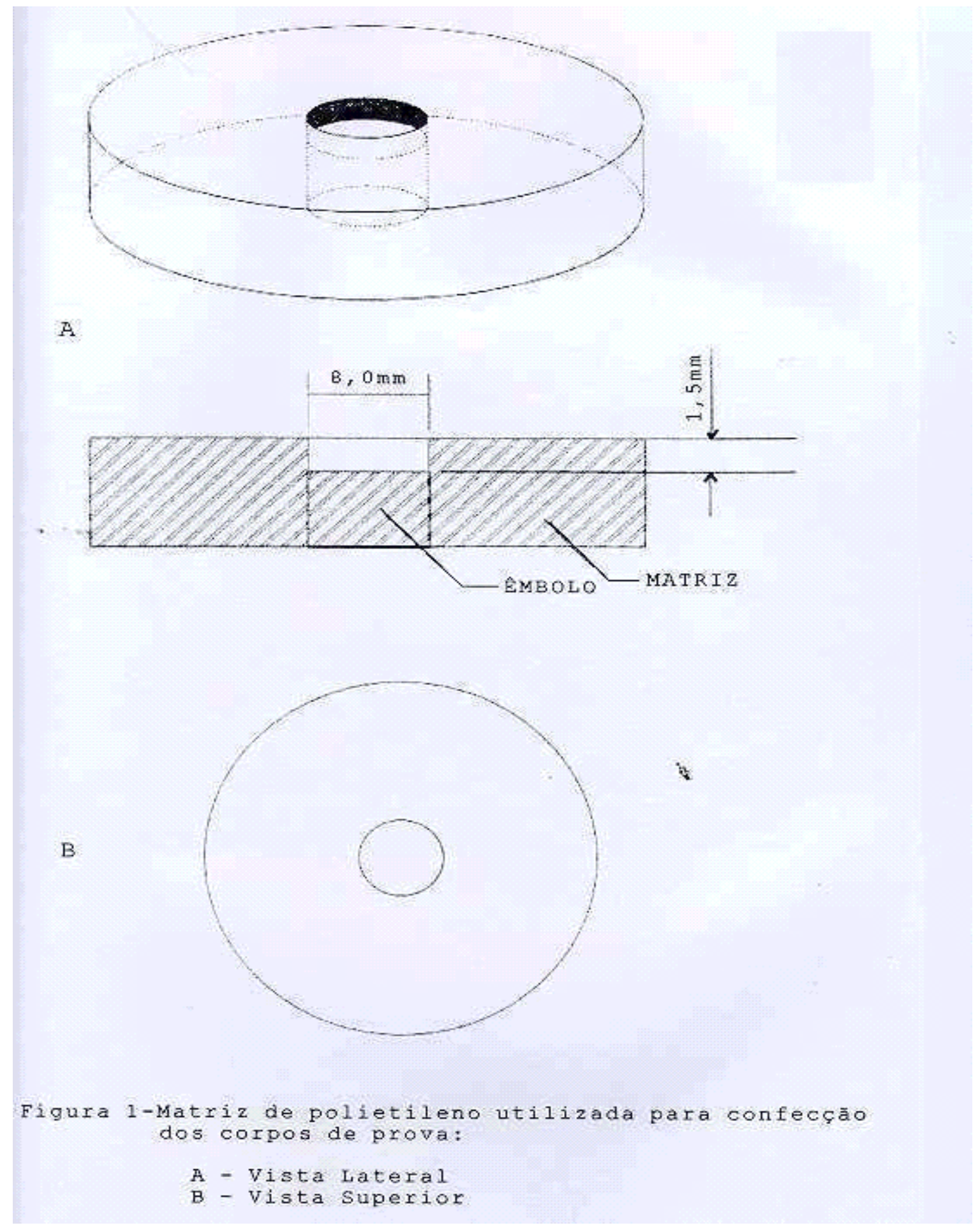




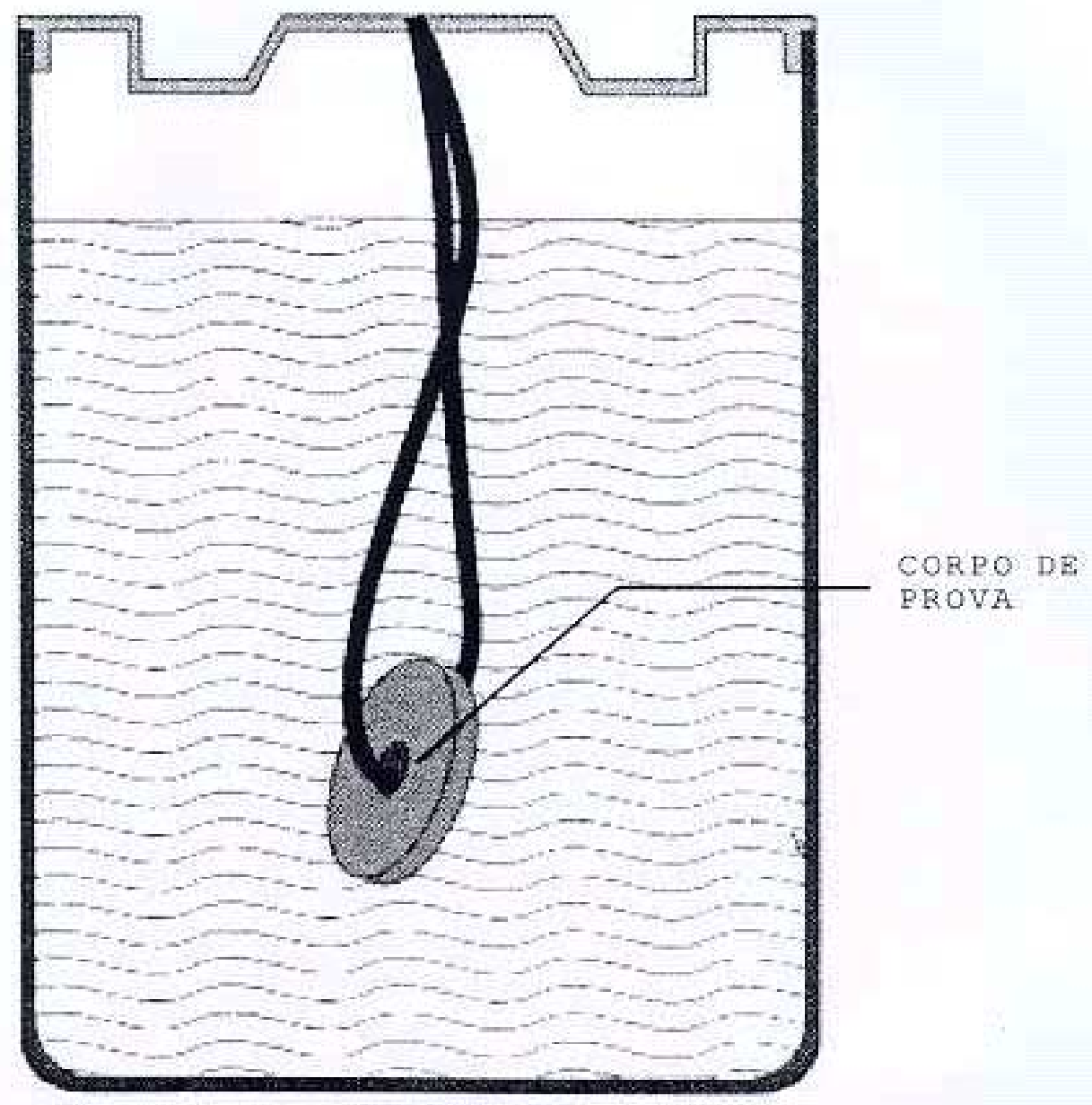

Figura 2-Corpo de prova suspenso em recipiente plastico contendo o meio de armazenagem. 
Após serem tampados e identificados, os recipientes foram levados à estufa e mantidos à temperatura de $37 \pm 1^{\circ} \mathrm{C}$ durante os períodos de leitura.

Foram determinados três períodos de leitura - 24 horas, 7 dias e 28 dias - e para cada material e cada período de leitura foram confeccionados 6 corpos de prova. Para o período de 24 horas as leituras foram realizadas a cada 6 horas; para o período de 7 dias, a cada 24 horas e para o período de 28 dias, a cada 7 dias, sendo que a cada intervalo dos três períodos de leitura os corpos de prova foram transferidos a meio de armazenagem fresco.

A concentração de íons flúor em solução foi obtida mediante leitura potenciométrica utilizando-se um eletrodo íon-específico modelo 94-09 e outro de referência modelo 9001, da Orion Research Inc., ambos acoplados a um aparelho analisador de íons modelo SA-720 (PROCYON Instrumentação Científica Ltda) (figura 3). O sistema aparelho-eletrodo foi calibrado, a cada 24 horas, com soluções padrão de fluoreto de sódio a 1 ppm e 10 ppm conforme recomendações do fabricante.

Após a remoção do recipiente plástico da estufa e previamente à leitura foram adicionados aos $18 \mathrm{~mL}$ de água desionizada 2,0 mL de solução tampão TISAB III, da ANALION Ind. e Com. Ltda, basicamente com 3 finalidades: ajustar a 
força iônica 3 4, 29, 35, 49,50,53,63, ○ pH da solução 4, 6, 29,53 e descomplexar os íons flúor $3,4,5,12,29,63$.

o recipiente, ao qual adicionalmente colocou-se uma barrinha magnética plastificada, foi posicionado sobre um agitador magnético da K-Line para a homogenização da solução. Em seguida, os dois eletrodos foram mergulhados na solução, aguardando-se a leitura realizada pelo sistema. Após o registro do resultado, o conteúdo do recipiente foi desprezado, sendo os eletrodos lavados com água desionizada e secos com papel absorvente, estando prontos para a próxima leitura.

Os resultados fornecidos pelo aparelho e expressos em ppm foram convertidos para $\mu g \mathrm{~F}^{-} / \mathrm{mm}^{2}$, levando-se em conta a área de superfície do corpo de prova (aproximadamente 138, $\left.16 \mathrm{~mm}^{2}\right)$.

Para a comprovação das diferenças na quantidade de liberação de flúor dos cimentos ionoméricos testados, utilizou-se a análise de variância (ANOVA) e para comparações individuais, o teste de Tukey-Kramer e de Student - Newman - Keuls. 


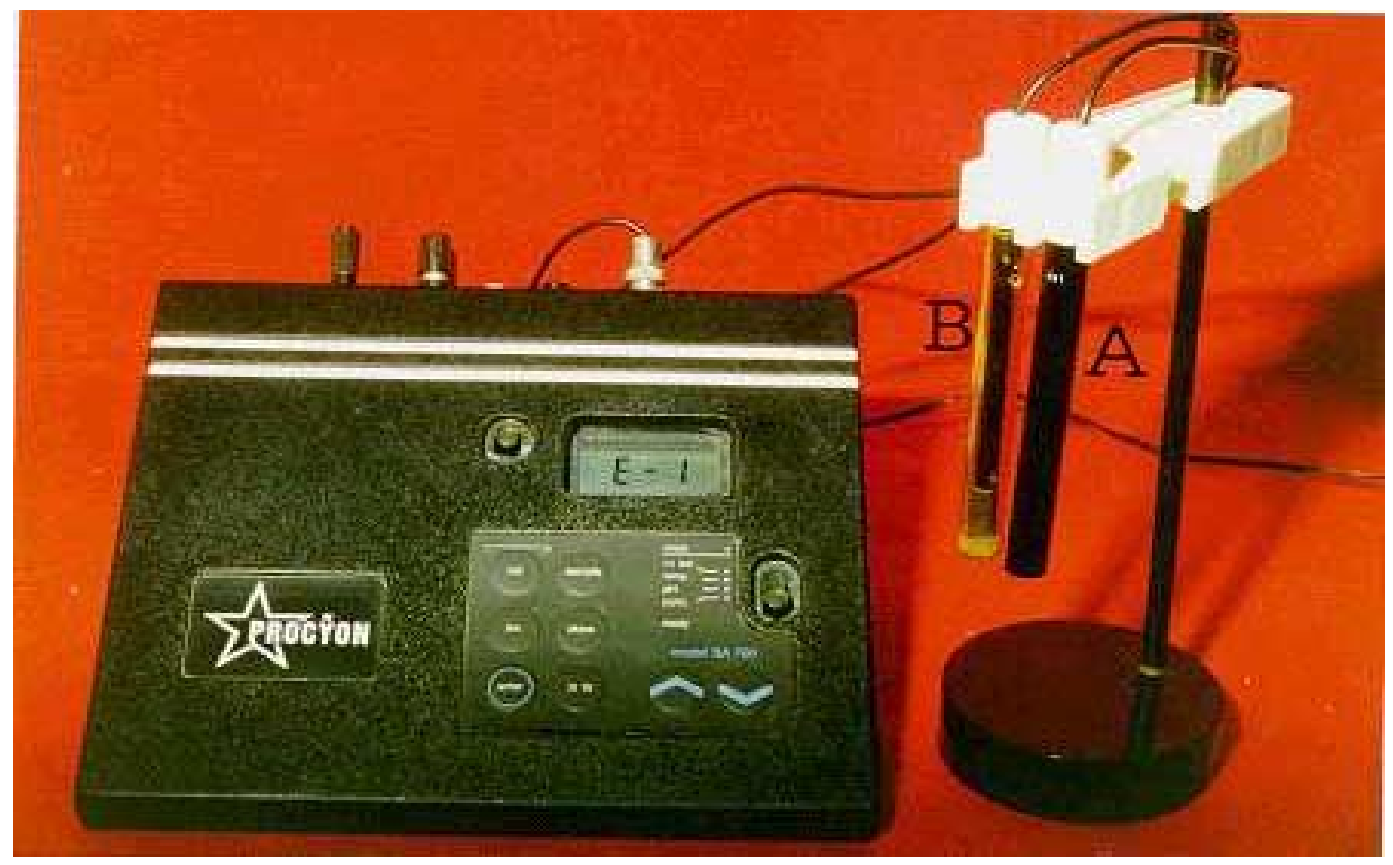

Figura 3 - Aparelho analisador de íons modelo SA-720:
A - eletrodo íon-específico modelo 94-09
B - eletrodo de referência modelo 90-01 


\title{
5 - Resultados
}

\begin{abstract}
Quantidades mensuráveis de liberação de flúor foram registradas para todos os materiais testados durante os três períodos de leitura. Os valores de liberação de flúor dos 6 corpos de prova de cada material em cada intervalo dos três períodos avaliados podem ser observados nas tabelas I a XXIV dos Apêndices.
\end{abstract}

Nas tabelas 1,2 e 3 relacionadas a seguir estão representadas, primeiramente, as análises comparativas dos valores médios totais ou cumulativos da liberação de flúor, isto é, a somatória das médias registradas em cada intervalo de leitura, dos 8 materiais testados, dos períodos de 24 horas, 7 dias e 28 dias respectivamente.

A análise de variância (ANOVA) a um critério de classificação constatou a ocorrência de diferenças estatisticamente significantes $(p<0,01)$ na quantidade de liberação de flúor dos cimentos ionoméricos testados. 
Tabela 1- Análise comparativa da liberação de flúor cumulativa entre os materiais no período de 24

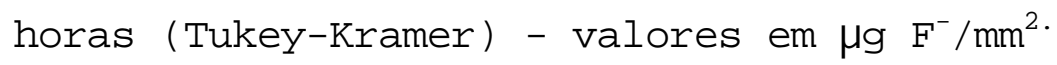

\begin{tabular}{|c|c|c|c|c|}
\hline MATERIAL & & & $\pm \quad$ DESVIO & PADRÃO \\
\hline Vidrion C & 3,693 & \pm & 0,570 & 7 \\
\hline XR Ionomer & 3,340 & \pm & 0,260 & \\
\hline Ketac-Bond & 1,671 & \pm & 0,174 & \\
\hline Shofu I & 0,967 & \pm & 0,173 & 7 \\
\hline Vitrebond & 0,859 & \pm & 0,220 & \\
\hline Ketac-Cem & 0,648 & \pm & 0,081 & \\
\hline GC Fuji I & 0,621 & \pm & 0,058 & - \\
\hline Zionomer & 0,043 & \pm & 0,007 & \\
\hline pó/líquido & & & & \\
\hline
\end{tabular}

Os valores unidos por colchete não são estatisticamente diferentes $(p<0,01)$. 
Tabela 2- Análise comparativa da liberação de flúor cumulativa entre os materiais no período de 7

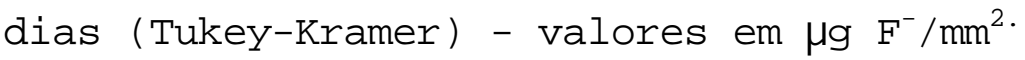

\begin{tabular}{lccl}
\hline MATERIAL & \multicolumn{2}{c}{ MÉDIA } & \pm DESVIO PADRÃO \\
\hline Vidrion C & 9,471 & \pm & 0,977 \\
XR Ionomer & 5,950 & \pm & 0,653 \\
Ketac-Bond & 3,577 & \pm & 0,347 \\
Shofu I & 3,244 & \pm & 0,367 \\
Vitrebond & 2,170 & \pm & 0,400 \\
Ketac-Cem & 1,422 & \pm & 0,213 \\
GC Fuji I & 1,381 & \pm & 0,111 \\
Zionomer & 0,094 & \pm & 0,018 \\
pó/líquido & & &
\end{tabular}

Os valores unidos por colchete não são estatisticamente diferentes $(p<0,01)$. 
Tabela 3- Análise comparativa da liberação de flúor cumulativa entre os materiais no período de 28

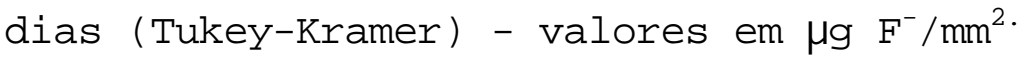

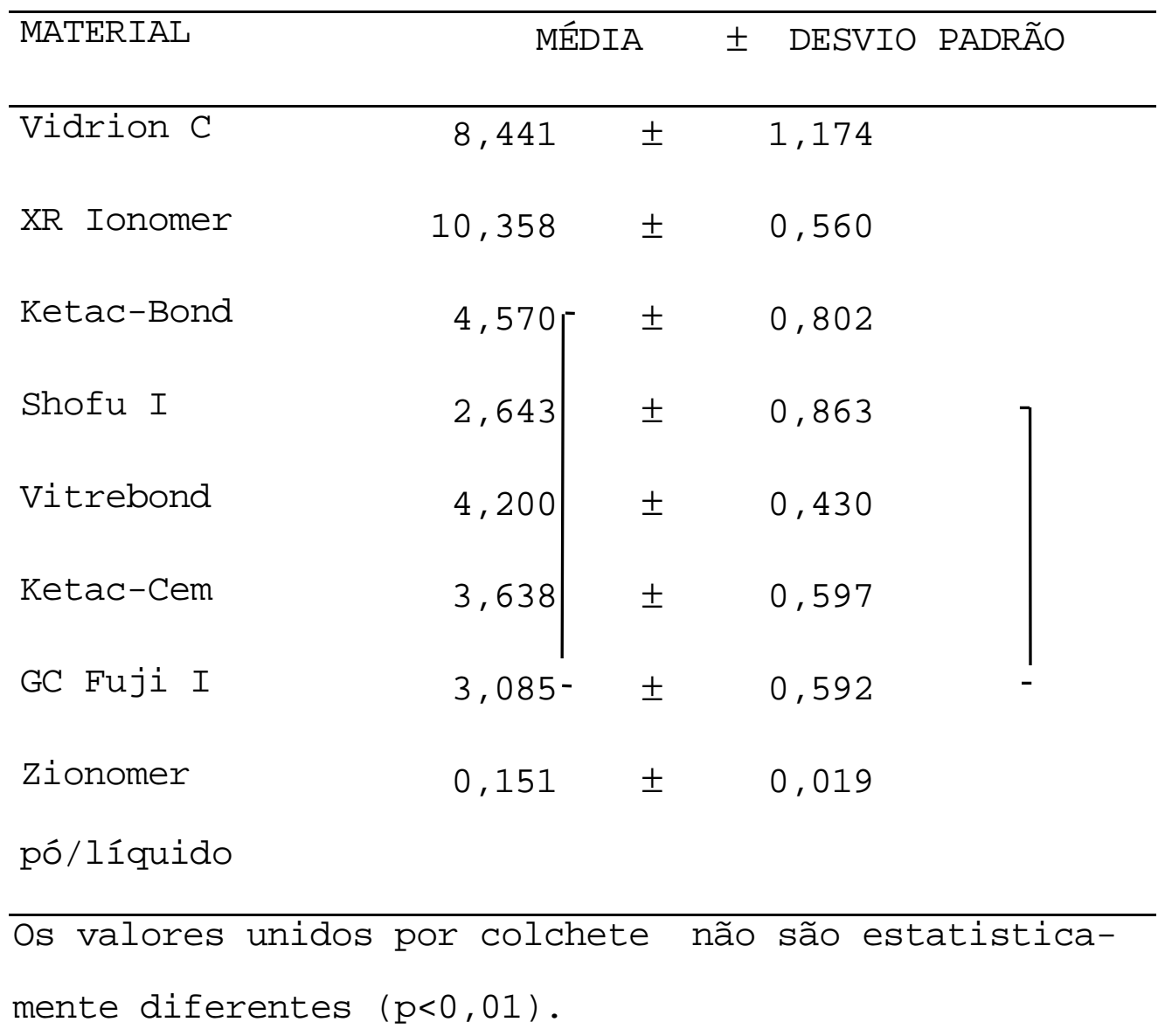


No período de leitura de 24 horas os maiores valores cumulativos foram registrados para o Vidrion C e XR Ionomer, seguidos pelo Ketac-Bond, Shofu I, Vitrebond, Ketac-Cem, GC Fuji I e por último, o Zionomer pó/líquido. De acordo com o teste de Tukey-Kramer utilizado para comparações individuais, não houve diferença estatisticamente significante $(p<0,01)$ entre os valores registrados para o Vidrion C e XR Ionomer e para o Shofu I, Vitrebond, KetacCem e GC Fuji I. O Zionomer pó/líquido, em comparação aos outros materiais, liberou uma quantidade mínima de flúor.

No período de leitura de 7 dias foi mantida a mesma ordem ou classificação entre os materiais, todavia o Vidrion C apresentou um valor cumulativo de liberação de flúor estatisticamente maior que aquele do XR Ionomer. O Zionomer pó/líquido continuou destacando-se, de maneira negativa, dos demais materiais.

Já no período de leitura de 28 dias, ocorreu uma inversão nos valores cumulativos registrados para os materiais. O XR Ionomer passou a liberar a maior quantidade de flúor, sendo seguido pelo Vidrion C que apresentou uma liberação significantemente menor. A seguir, não houve diferença estatisticamente significante $(p<0,01)$ entre os 
valores registrados para o Ketac-Bond, Vitrebond, Ketac-Cem e GC Fuji I. Na seqüência, o Shofu I apresentou um valor de liberação menor, entretanto não houve diferença estatisticamente significante $(\mathrm{p}<0,01)$ entre os valores registrados para o Ketac-Cem, GC Fuji I e Shofu I. O Zionomer pó/líquido manteve-se na mesma classificação, liberando uma quantidade mínima de flúor.

Nas figuras 4,5 e 6 pode-se melhor visualizar e comparar os valores cumulativos registrados para os 8 materiais testados nos períodos de 24 horas, 7 dias e 28 dias respectivamente.

Para a comparação do padrão de liberação de flúor, isto é, das características comportamentais durante o tempo, analisou-se a quantidade de liberação de flúor de cada material em cada intervalo de leitura dos três períodos de avaliação.

As análises comparativas da liberação de flúor entre os 8 cimentos de ionômero de vidro nos intervalos de leitura dos períodos de 24 horas, 7 dias e 28 dias estão representadas, respectivamente, nas tabelas 4, 5 e 6 . 


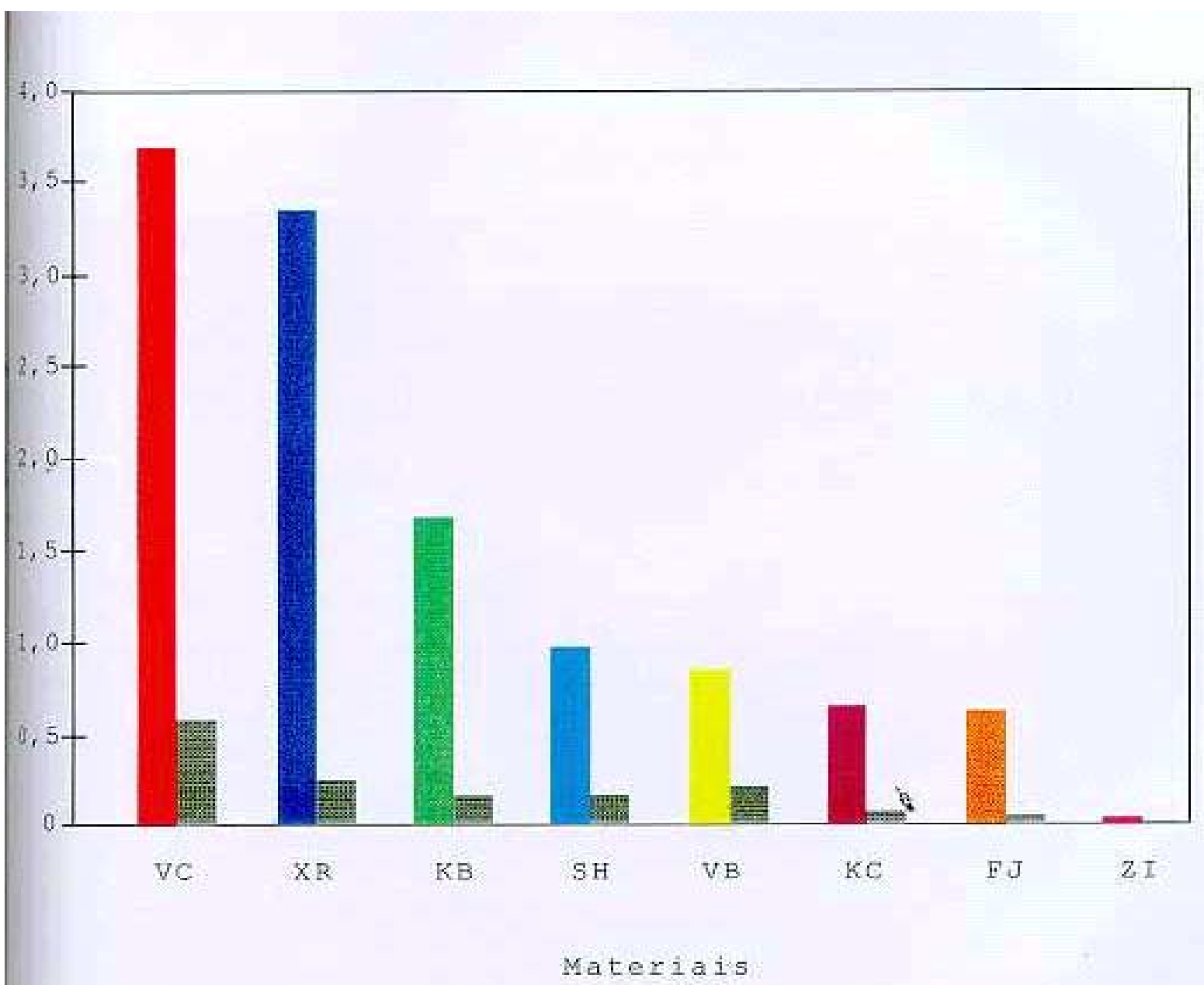

Figura 4-Medias e desvios padräo cumulativos da 1 iberaça de flúor dos cimentos de ionomero de vidro no periodo de leitura de 24 horas. 


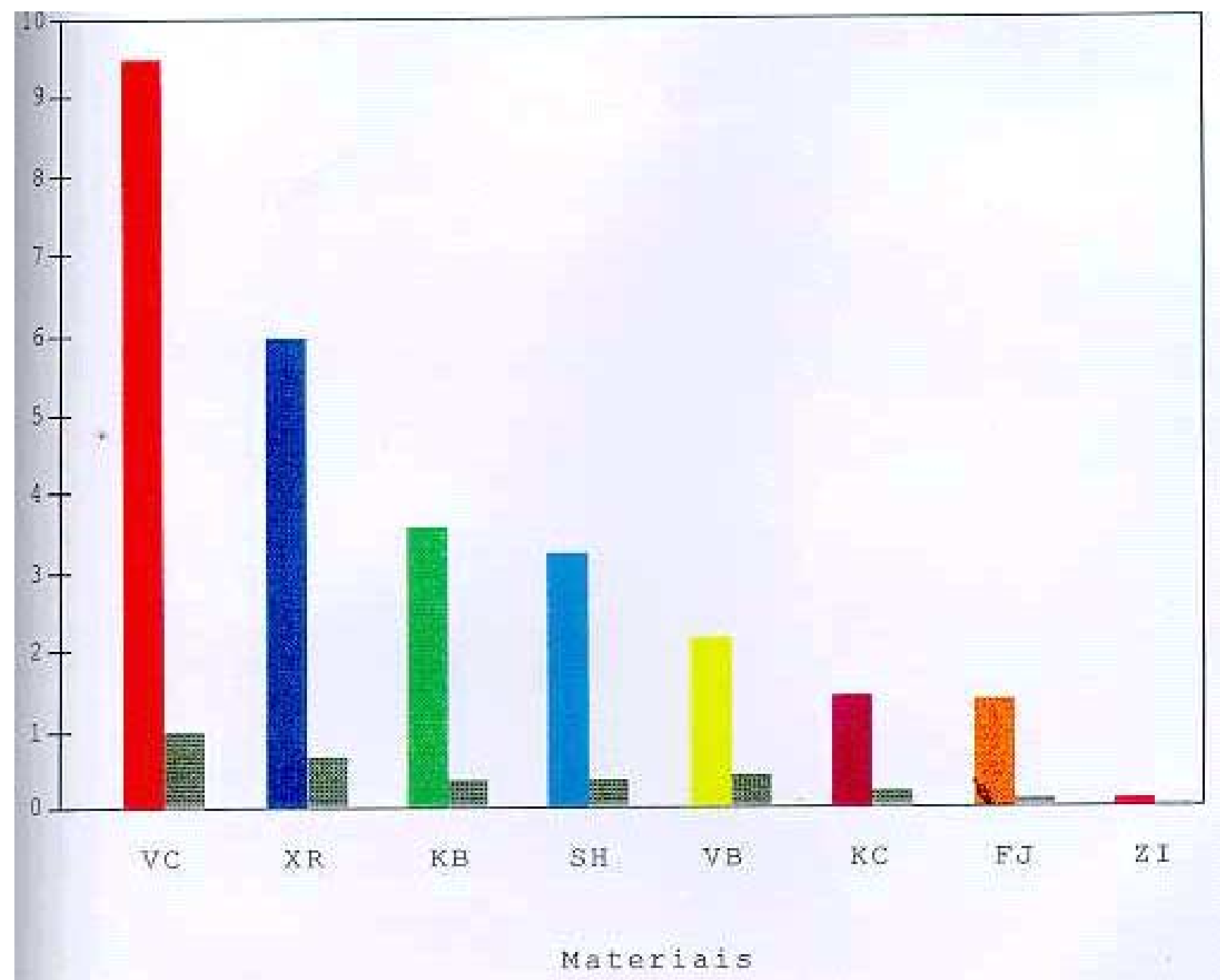

Eigura 5-Médias e desvios padräo cumulativos da liberaçăo de flúor dos cimentos de ionómero de vidro no periodo de leitura de 7 dias. 


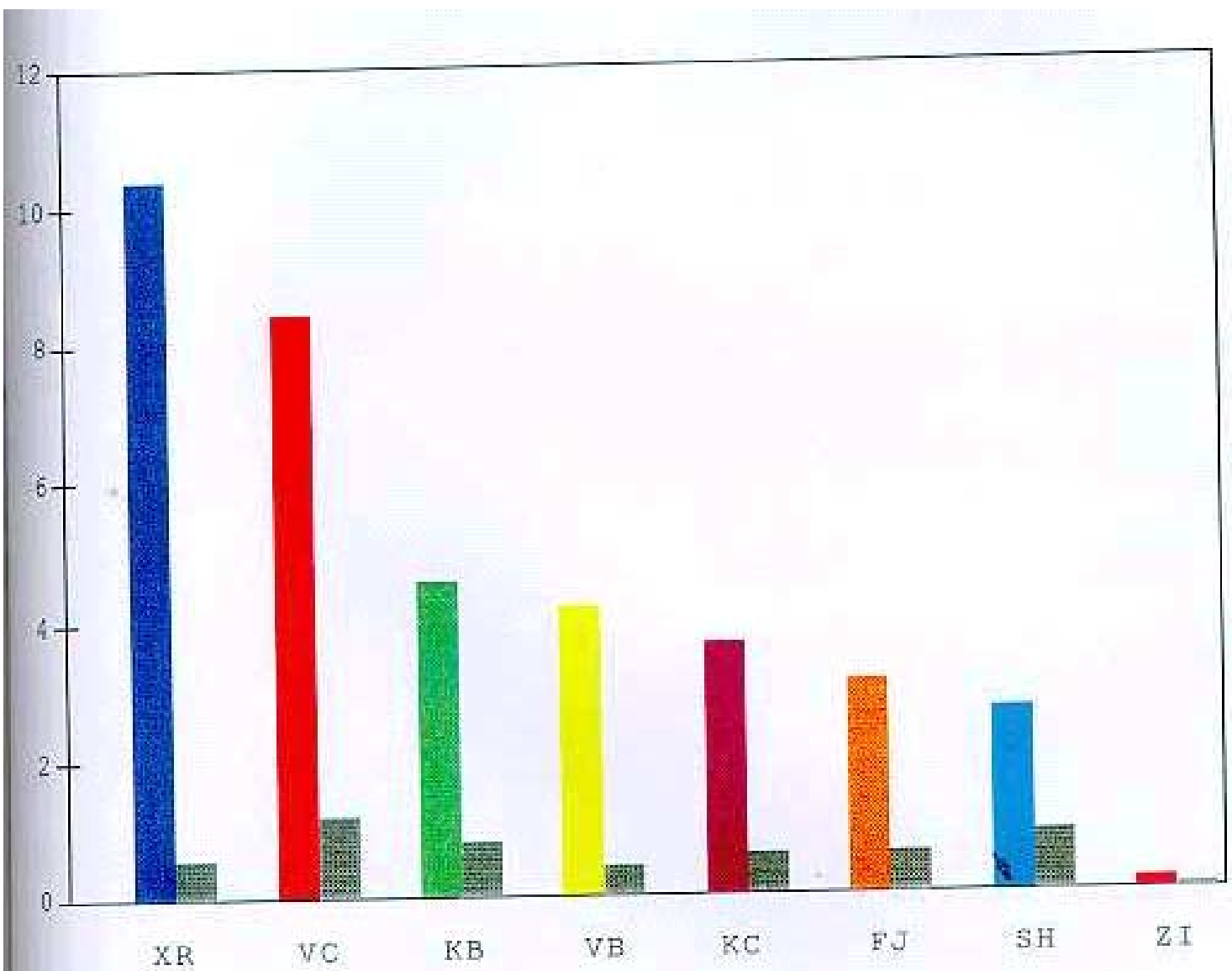

Materiais

Eigura 6- Médias e desvios padrao cumulativos da liberacáo de flior dos cimentos de ionomero
do vidro no periodo de leitura de 28 dias. 


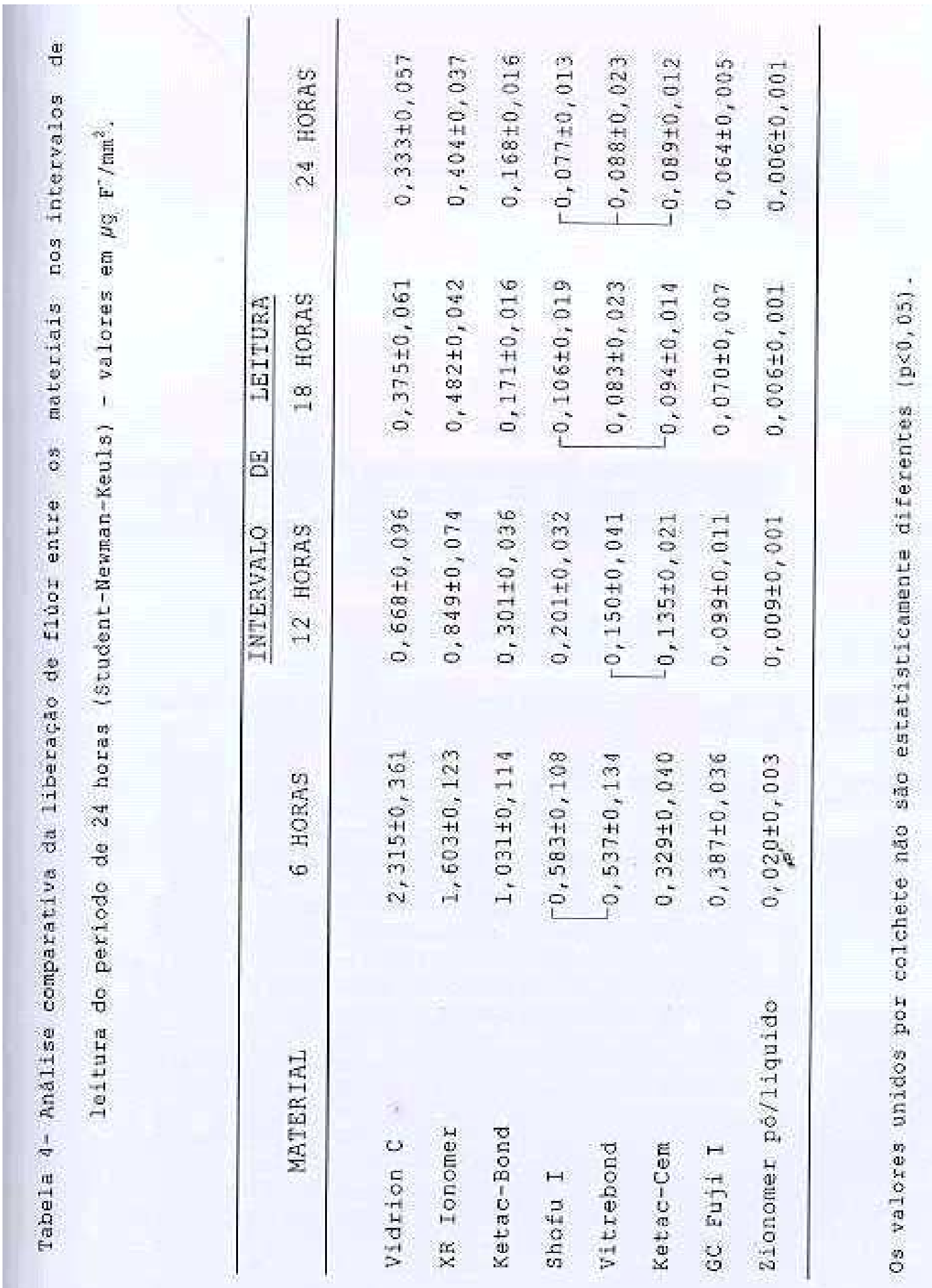




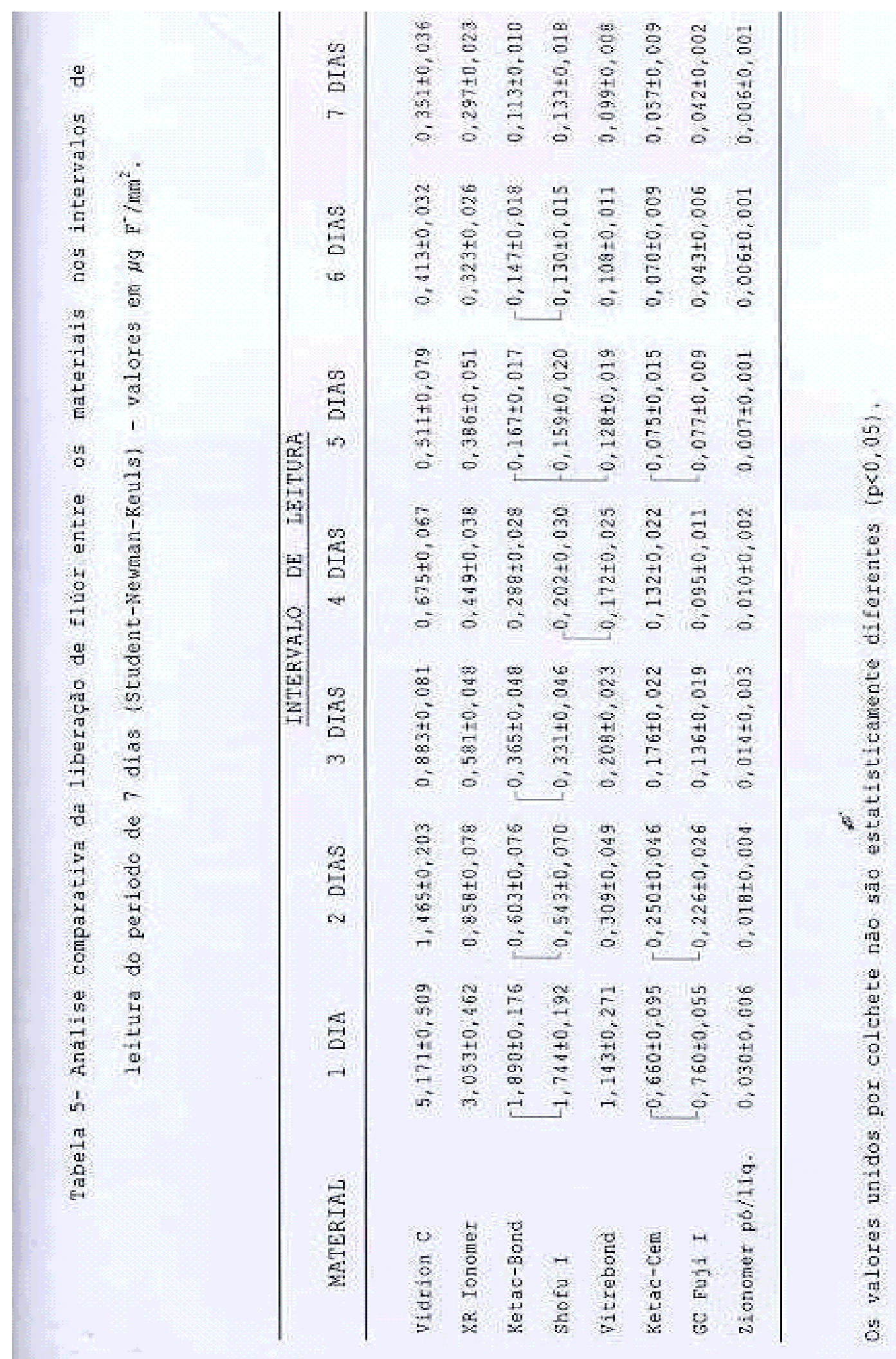



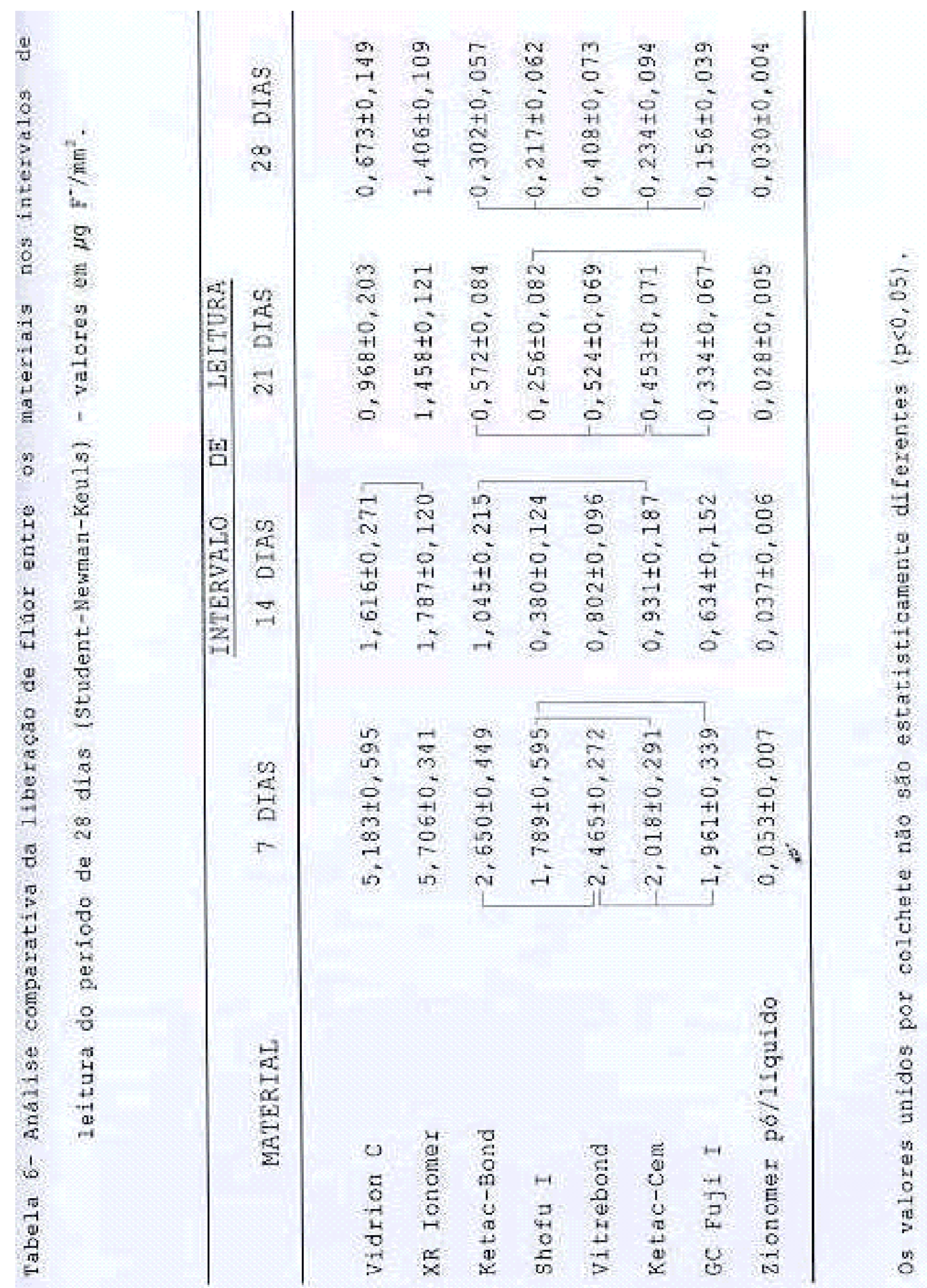
No primeiro intervalo de leitura ( 6 horas) do período de 24 horas os maiores valores de liberação foram registrados para o Vidrion $\mathrm{C}$, seguido pelo XR Ionomer, Ketac-Bond, Shofu I, Vitrebond, GC Fuji I, Ketac-Cem e por último, o Zionomer pó/líquido. De acordo com o teste de Student - Newman - Keuls, utilizado para comparações individuais, não houve diferença estatisticamente significante $(p<0,05)$ somente entre os valores registrados para o Shofu I e Vitrebond.

No segundo intervalo de leitura (12 horas) do período de 24 horas foi observada uma queda acentuada na quantidade de liberação de flúor do Vidrion C, tornando-se inclusive significantemente menor que a quantidade registrada para o $\mathrm{XR}$ Ionomer. Exceto $\mathrm{O}$ Vidrion $\mathrm{C}$, os demais materiais apresentaram uma queda gradual na quantidade de liberação de flúor, sendo que o Ketac-Cem passou a liberar uma quantidade significantemente maior que o GC Fuji I.

No terceiro intervalo de leitura (18 horas) do período de 24 horas registrou-se novamente e agora para todos os materiais, uma queda gradual na quantidade de liberação de flúor. O Ketac-Cem passou a liberar uma quantidade significantemente maior também com relação ao Vitrebond. 
No quarto intervalo de leitura (24 horas) do período de 24 horas foram registrados valores aproximadamente constantes, exceto para o shofu I que apresentou uma queda gradual na quantidade de liberação de flúor. Verificou-se uma ordem decrescente dos valores de liberação de flúor diferente daquela do intervalo de 6 horas, como segue: XR Ionomer, Vidrion C, Ketac-Bond, Ketac-Cem, Vitrebond, Shofu I, GC Fuji I e Zionomer pó/líquido, não havendo diferença estatisticamente significante $(\mathrm{p}<0,05)$ entre os valores registrados para o Ketac-Cem e Vitrebond, Ketac-Cem e Shofu I e Vitrebond e Shofu I.

A figura 7 apresenta, graficamente, as características comportamentais dos 8 materiais testados nos intervalos de leitura do período de 24 horas.

No primeiro intervalo de leitura (1 dia) do período de 7 dias foi registrada a mesma ordem decrescente de liberação de flúor dos materiais verificada no primeiro intervalo de leitura (6 horas) do período de 24 horas, como segue: Vidrion C, XR Ionomer, Ketac-Bond, Shofu I, Vitrebond, GC Fuji I, Ketac-Cem e Zionomer pó/líquido. Todavia, não houve diferença estatisticamente significante $(p<0,05)$ entre os 
valores registrados para o Ketac-Bond e Shofu I e para GC Fuji I e Ketac-Cem.

No segundo intervalo de leitura (2 dias) do período de 7 dias observou-se, novamente, uma queda acentuada na quantidade de liberação de flúor do Vidrion C e agora também do XR Ionomer, sendo que os demais materiais apresentaram uma queda gradual. A ordem entre os materiais permaneceu, exceto para o Ketac-Cem que passou a liberar uma quantidade maior, porém não estatisticamente significante $(p<0,05)$, que o GC Fuji I.

No terceiro, quarto e quinto intervalos de leitura (3, 4 e 5 dias) do período de 7 dias os materiais continuaram a apresentar quedas graduais na quantidade de liberação de flúor. No quinto intervalo de leitura o GC Fuji I voltou a liberar uma quantidade maior de flúor que o Ketac-Cem, porém não estatisticamente significante $(p<0,05)$.

No sexto e sétimo intervalos de leitura ( 6 e 7 dias) do período de 7 dias foram registrados valores aproximadamente constantes para os materiais, entretanto, no sexto intervalo, o Ketac-Cem novamente passou a liberar uma quantidade de flúor significantemente maior que o GC Fuji I 
e no sétimo intervalo, o shofu I passou a liberar significantemente mais flúor que o Ketac-Bond.

Durante todo o período de leitura de 7 dias o Zionomer pó/líquido também destacou-se, de maneira negativa, dos demais materiais, liberando quantidades mínimas de flúor.

A figura 8 apresenta, graficamente, as características comportamentais dos 8 materiais testados nos intervalos de leitura do período de 7 dias.

No período de 28 dias, cujas leituras foram realizadas semanalmente, ocorreu uma inversão na ordem dos materiais com relação à quantidade de flúor liberado.

No primeiro intervalo de leitura (7 dias) registrou-se - maior valor de liberação de flúor para o XR Ionomer, sendo seguido pelo Vidrion C que apresentou uma liberação significantemente menor. Na seqüência, registrou-se a seguinte ordem decrescente entre os materiais: Ketac-Bond, Vitrebond, Ketac-Cem, GC Fuji I, Shofu I e Zionomer pó/líquido. Não houve diferença estatisticamente significante $(p<0,05)$ entre os valores registrados para o Ketac-Bond e Vitrebond, para o Vitrebond e Ketac-Cem e Vitrebond e GC Fuji I e para o Ketac-Cem e GC Fuji I, KetacCem e Shofu I e GC Fuji I e Shofu I. 
No segundo intervalo de leitura (14 dias), após queda acentuada na quantidade de liberação de flúor do XR Ionomer e Vidrion C e queda gradual para os demais materiais, o XR Ionomer continuou a liberar a maior quantidade de flúor, porém não estatisticamente diferente $(\mathrm{p}<0,05)$ daquela registrada para o Vidrion C. Exceção feita ao Ketac-Cem, que passou a liberar uma quantidade significantemente maior que o Vitrebond, não houve qualquer outra variação na ordem entre os materiais.

No intervalo de leitura de 21 dias o XR Ionomer voltou a liberar uma quantidade significantemente maior que aquela registrada para o Vidrion C. O Vitrebond voltou a liberar uma quantidade maior, porém não estatisticamente significante $(p<0,05)$, que aquela registrada para o KetacCem. Também não foi observada diferença estatisticamente significante $(p<0,05)$ entre os valores registrados para o Ketac-Bond e Vitrebond e Ketac-Bond e Ketac-Cem, para o Ketac-Cem e GC Fuji I e para o GC Fuji I e Shofu I.

No intervalo de leitura de 28 dias $\circ$ XR Ionomer apresentou um valor de liberação de flúor aproximadamente constante e significantemente maior que os valores registrados para os demais materiais. O Vitrebond passou a 
liberar uma quantidade significantemente maior também com relação ao Ketac-Bond. O Shofu I, apesar de apresentar um valor aproximadamente constante com relação ao intervalo de leitura anterior, passou a liberar uma quantidade maior, porém não estatisticamente significante $(p<0,05)$, que o GC Fuji I. Não foi observada diferença estatisticamente significante $(p<0,05)$ entre os valores registrados para o Ketac-Bond e Ketac-Cem e Ketac-Bond e Shofu I, para o Ketac-Cem e Shofu I e Ketac-Cem e GC Fuji I.

Da mesma forma que nos períodos de leitura anteriores, - Zionomer pó/líquido liberou quantidades mínimas de flúor quando comparado aos demais materiais. Os valores de liberação de flúor registrados para esse material tornaramse aproximadamente constantes a partir do segundo intervalo de leitura (14 dias) .

A figura 9 apresenta, graficamente, as características comportamentais dos 8 materiais testados nos intervalos de leitura do período de 28 dias.

$$
\text { Analisando-se os resultados pôde-se verificar que, }
$$
apesar das diferenças na quantidade de liberação de flúor registrada para cada material em cada intervalo de leitura, as características comportamentais ou o padrão de liberação 
de flúor foi semelhante para todos os materiais nos três períodos de avaliação. Observou-se um "burst effect" (efeito explosão) como citado por COOLEY; MCCOURT ${ }^{4}$ e MCCOURT; COOLEY; HUDDLESTON ${ }^{40}$, onde registrou-se um alto valor de liberação de flúor nos primeiros intervalos de leitura, seguindo-se uma queda acentuada e/ou gradual, de acordo com cada material tendendo a valores constantes no transcorrer do tempo 


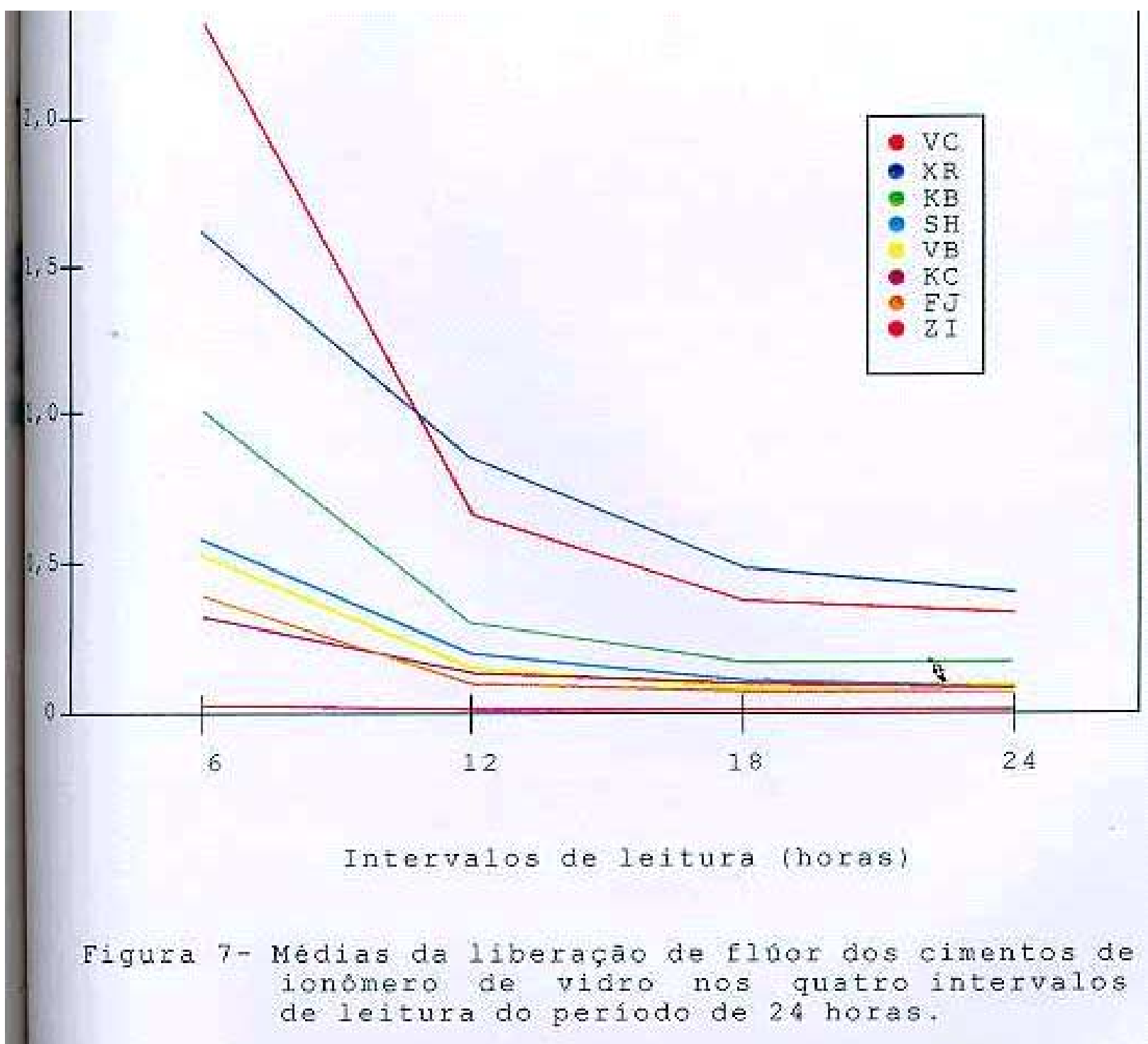




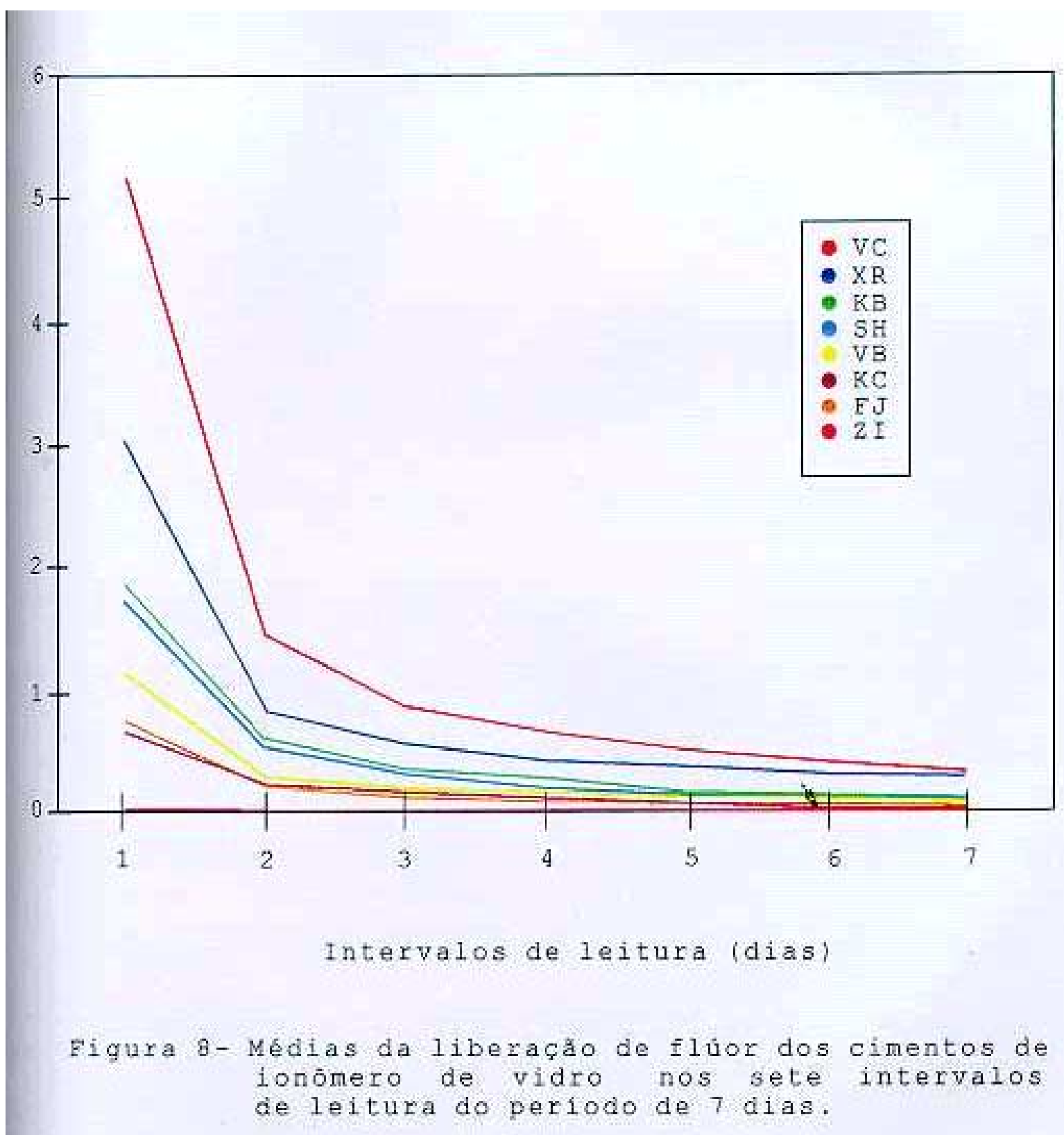




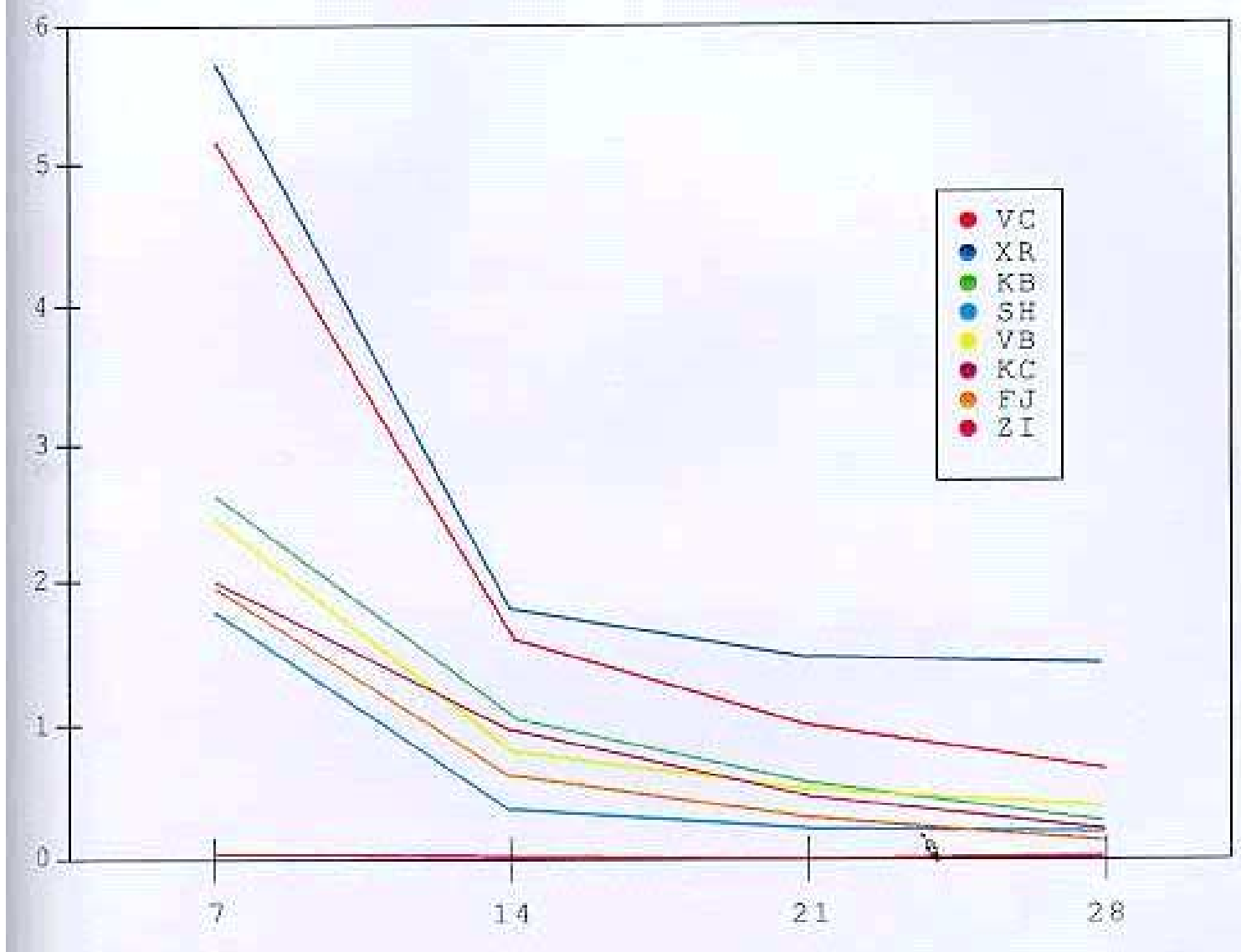

Intervalos de leitura (dias)

Figura 9-Medias da liberaça de fluor dos cimentos de ionsmero de vidro nos quatro intervalos de leitura do periodo de 28 dias. 


\section{6 - Discussão}

\section{1 - Da Metodologia}

$\mathrm{Na}$ literatura encontram-se inúmeros trabalhos que avaliam a propriedade de liberação de flúor de materiais odontológicos, entretanto nota-se a ausência de uma metodologia padrão que possa ser reconhecida como a de escolha. A diversidade dos métodos utilizados nos trabalhos impossibilita a realização de comparações quantitativas entre os resultados.

Em linhas gerais, a metodologia utilizada para os testes in vitro de liberação de flúor consiste na confecção de corpos de prova dos materiais a serem avaliados que são suspensos em um meio líquido durante intervalos de tempo variáveis. A quantidade de flúor liberado no meio de armazenagem é mensurada por um eletrodo íon-específico acoplado a um aparelho analisador de íons. Todavia, como já mencionado, existem inúmeras variáveis dessa metodologia básica, desde a fase de manipulação dos materiais até a fase de mensuração ou leitura do flúor liberado e registro dos resultados.

A manipulação dos materiais geralmente é realizada em ambiente refrigerado à temperatura de $23 \pm 2{ }^{\circ} \mathrm{C}$, de acordo com as recomendações dos fabricantes. Uma variável relaciona-se ao proporcionamento dos componentes pó e líquido que em 
certos trabalhos $3, \mathbf{5}, \mathbf{4 4}, \mathbf{4 8}, \mathbf{4 9}, \mathbf{6 3}, \mathbf{6 5}, \mathbf{7 3}$ é realizado por peso e, em outros $\mathbf{1 2}, \mathbf{4 7}, \mathbf{5 3}, \mathbf{7 2}$, por volume. Uma maior padronização é obtida quando o proporcionamento é realizado por peso, entretanto como certos fabricantes não mencionam qual é a proporção pó/líquido em gramas, optou-se pela realização do proporcionamento por volume com todos os cimentos de ionômero de vidro testados.

Para a avaliação da liberação de flúor de amostras dos materiais, a maior parte dos autores opta pela confeç̧ão de corpos de prova que se apresentam em diferentes dimensões e geometrias, geralmente em forma discóide $1,2,4,5,6,13,14,15,18,19,20,24,26,35,38,40,41,42,48,49,50$, $53,56,58,59,60,64,65,67,72,73$, cilíndrica 5, 11, 12,

54,72 ou retangular 16,17,21,63. Após a confecção, os corpos de prova normalmente são mantidos em repouso durante intervalos de tempo variáveis aguardando-se a reação de endurecimento inicial e, em seguida, são suspensos $1,5,14,24,27,28,38,42,48,59,60,63,64,72,73$ no meio de armazenagem geralmente através de um fio de seda. Desta forma, a área superficial total do corpo de prova permanece em contato com o meio líquido. O único trabalho em que foi mencionada a não suspensão foi o de TVEIT; GJERDET 65 , onde os corpos de prova foram colocados sobre um suporte de vidro e imersos no meio de armazenagem. 
Procurando aproximar-se da situação clínica alguns autores, de maneira diferente, não optaram pela confecção de corpos de prova. DERKSON; POON, RICHARDSON ${ }^{10}$ e MERYON; SMITH 47 utilizaram metodologia baseada em aparato que simulava um preparo cavitário. Deste modo, após a inserção, o material permanecia com apenas uma de suas faces exposta ao meio de armazenagem. MUZYNSKI et al.51, por sua vez, imergiram em saliva artificial troquéis de gesso que continham restaurações metálicas fundidas cimentadas com ionômero de vidro. MARTINS $\mathbf{4 4}$ realizou restaurações oclusais em prémolares humanos extraídos e GARCIA-GODOY; CHAN 25 E MEIRA 45 avaliaram a liberação de flúor de cimentos de ionômero de vidro para forramento sob restaurações de amálgama e resina composta. No presente trabalho, de acordo com a maior parte dos autores, optou-se pela confeç̧ão de corpos de prova em forma de disco e pela suspensão no meio de armazenagem, acreditando-se ser uma metodologia simples e facilmente reproduzível e padronizável.

Uma grande variabilidade entre os trabalhos relacionase ao meio de armazenagem, diferindo quanto ao tipo, pH, temperatura, presença ou não de agitação e realização ou não de troca ou substituição a intervalos regulares.

Com relação ao tipo, a maior parte dos autores utiliza água destilada $3,4,27,31,35,38,40,42,47,50,53,59$, 
60,72 , água desionizada $5,6,14,15,25,28,32,45,54,64,73$ ou água destilada desionizada $\mathbf{1 , 1 0 , 4 8 , 6 3 , 6 7}$. Outros autores, alternativamente, utilizam outros meios de armazenagem, tais como água corrente 18,19,20, ágar 26, albumina 53, ácido lático 15, soluções tampão de fosfato $16,17,21,49,53$ e de acetato de sódio + ácido acético $\mathbf{2 4}$ e ainda, soluções desmineralizantes $\mathbf{4 4 , 5 8}$ e remineralizantes $\mathbf{4 4}$. De acordo com GARCIA-GODOY; CHAN 25, a quantidade de flúor liberado nesses meios de armazenagem pode ser diferente daquela encontrada na cavidade bucal, pois a saliva é um meio em constantes mudanças quanto à temperatura, pH, conteúdo proteico e muitos outros fatores. Com base nisto, alguns autores $11, \mathbf{1 2}, \mathbf{1 4}, \mathbf{4 1}, \mathbf{5 1}, \mathbf{5 4}, \mathbf{6 5}$ utilizaram como meio de armazenagem saliva artificial e REZK-LEGA; ÖGAARD; RÖLLA 53, saliva humana não estimulada. Todavia, a película adquirida e a placa bacteriana, presentes clinicamente, podem atuar como uma barreira à difusão dos íons flúor e por isso, segundo HÖRSTED-BINDSLEV; LARSEN ${ }^{31}$, tanto a saliva artificial como a humana também não podem ser consideradas como meios de armazenagem ideais, pois não representam com fidelidade o que ocorre in vivo. Adicionalmente, problemas técnicos podem impedir a realização de leituras totais e completas do flúor liberado, pois pode haver formação de fluoreto de cálcio e 
outros complexos e, como se sabe, os eletrodos íonespecíficos somente detectam ou mensuram o flúor na forma iônica. Diante de tantas controvérsias, optou-se pela utilização da água desionizada como meio de armazenagem, pois apesar de não representar a complexidade do meio bucal, permite a realização de uma leitura total do flúor liberado. Além disso, a água desionizada não provoca a danificação dos eletrodos, fato passível de ocorrer se outros meios de armazenagem forem utilizados*

o pH está relacionado ao meio de armazenagem utilizado. $\mathrm{Na}$ maioria dos trabalhos $\mathrm{p} \mathrm{pH}$ foi neutro $1,3,4,5,6,10,12,15,19,20,27,28,31,32,35,38,40,42,44,47,48$, $50,53,58,59,60,63,64,67,72,73$, semelhante aos da água desionizada e cavidade bucal na maior parte do tempo. Alguns autores usaram pH ácido $14,15,16,17,18,21,24,41,44$, 49,53,58 e apenas um experimento 18 foi realizado em $\mathrm{pH}$ básico.

CRANFIELD; KUHN; WINTER 5 e JONES et al. 35 utilizaram como meio de armazenagem, respectivamente, água desionizada à temperatura de $10^{\circ} \mathrm{C}, 29^{\circ} \mathrm{C}$ e $37^{\circ} \mathrm{C}$ e água destilada à temperatura de $21^{\circ} \mathrm{C}$ e $37^{\circ} \mathrm{C}$. Neste trabalho optou-se pela manutenção da temperatura a $37^{\circ} \mathrm{C}$ visando

\footnotetext{
*RETIEF, D.H. (Faculdade de Odontologia da Universidadedo Alabama, Birmingham). Comunicação Pessoal, 1992 .
} 
simular a situação presente clinicamente a maior parte do tempo .

Na maioria dos trabalhos manteve-se o meio de armazenagem em repouso, entretanto alguns autores $10,16,17,45,64,67$ optaram pela realização de agitação. FUKAZAWA; MATSUYA; YAMANE 24 propuseram-se a avaliar a influência da agitação sobre a liberação de flúor dos cimentos de ionômero de vidro e, para isto, utilizaram o meio de armazenagem com e sem agitação, mantendo constantes as demais condições. Como os resultados não mostraram diferenças estatisticamente significantes, optamos por manter o meio de armazenagem sem agitação.

A realização de troca ou substituição do meio de armazenagem a intervalos regulares foi mencionada em certos trabalhos $10,11,12,14,16,17,31,42,58$. TVEIT; GJERDET 65 e MERYON; SMITH 47 não optaram pela troca ou substituição, sendo que o meio de armazenagem permaneceu inalterado durante todo o período de estudo para que a taxa de liberação de flúor não fosse afetada. FUKAZAWA; MATSUYA; YAMANE 24 também propuseram-se a avaliar a influência desta variável sobre a liberação de flúor dos cimentos de ionômero de vidro e não observaram diferenças estatisticamente significantes. Como a saliva é constantemente renovada no interior da cavidade bucal, a troca ou substituição do meio 
de armazenagem simula, de uma maneira mais apropriada, a condição clínica. Além disso, segundo KUHN; WILson 39 , a concentração de flúor liberado pelo cimento de ionômero de vidro em uma solução pode variar com o tempo, aumentando ou diminuindo conforme o patamar de concentração iônica, pressupondo a reabsorção intermitente do flúor pelo próprio cimento. Supondo-se que o mecanismo de liberação de flúor seja um processo de difusão baseado na lei de Fick, segundo a qual "o fluxo dos solutos que se movem através de um campo limitado diminui à medida que a concentração do soluto aumenta no outro lado", DERKSON; POON; RICHARDSON 10 acreditam que uma menor quantidade de flúor será liberada se a solução não for trocada periodicamente. Em função dessas observações, optou-se pela renovação do meio de armazenagem após cada leitura, uma vez que a intenção era observar o potencial absoluto de liberação de flúor das amostras.

Menciona-se a adição de uma solução tampão ao meio de armazenagem previamente à realização da mensuração ou leitura do flúor liberado, tendo como finalidades ajustar a força iônica $3,4,29,35,49,50,53,63$, ○ pH da solução 4, 6, 29,53, propiciando leituras padronizadas, e descomplexar os íons flúor $\mathbf{3}, \mathbf{4}, \mathbf{5}, \mathbf{1 2}, \mathbf{2 9}, \mathbf{6 3}$. A solução tampão TISAB (Total Ionic Strength Adjustment Buffer) é a mais comumente utilizada e, em grande parte dos trabalhos 
$3,4,6,11,12,14,27,35,41,47,49,50,51,53,59,60,64,72$, não é feita menção ao tipo de TISAB utilizado. CRANFIELD; KUHN; WINTER $^{5}$, MILLER et al. ${ }^{48}$, STANNARD; VIAZIS 58 e TAY; BRADEN 63 utilizaram a solução tampão TISAB II e CARVALHo et al.1, DEVLIN et al. ${ }^{13}$, GARIB $^{26}$ e MEIRA ${ }^{45}$, a solução tampão TISAB III. FORSs ${ }^{15}$ utilizou uma solução tampão de citrato e acetato. Neste trabalho utilizou-se a solução tampão TISAB III por acreditar-se ser a mais indicada de acordo com a origem e natureza do meio de armazenagem.

Para a leitura do flúor liberado, com exceção de TVEIT; GJERDET ${ }^{65}$ que utilizaram $\circ$ método espectofotométrico, de VERBEECK et al. 67 que utilizaram a cromatografia de íon e de

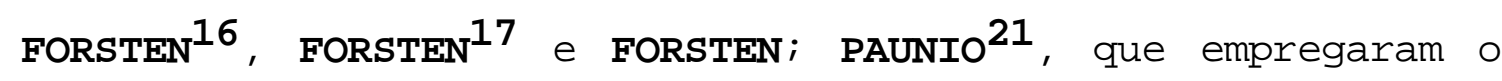
método indireto da análise do flúor absorvido pela hidroxiapatita sintética presente no meio de armazenagem, os demais autores lançaram mão do método potenciométrico direto através do uso de aparelhos analisadores de íons que, comparado aos métodos clássicos, é veloz, simples e exato. Existem diversos tipos e modelos de aparelhos analisadores de íons. O modelo SA-720, da PROCYON, utilizado neste trabalho, possui uma escala para leitura direta da concentração de íons flúor, sendo o sistema de detecção 
constituído por um eletrodo sensível ao flúor e um eletrodo de referência.

Os resultados obtidos pelos diferentes métodos de leitura são expressos, entre outros, em ppm $1,2,6,14,18,19,20,27,31,47,51,52,53,73 \quad \mathrm{e}, \quad$ levando-se em conta a área superficial total do corpo de prova, em $\mu \mathrm{g}$ $\mathrm{F}^{-} / \mathrm{mm}^{211}, 12,38,40,48,59,64,65$. Por acreditarem que o flúor é liberado do volume total da amostra, alguns autores expressam os resultados em $\mu \mathrm{g} \mathrm{F}^{-} / \mathrm{mm}^{350}$ e $\mathrm{mg} \mathrm{F}^{-} / \mathrm{cm}^{331,} 32$.

O tempo de armazenagem das amostras dos materiais antes de cada leitura e o período total do experimento varia grandemente nos diferentes trabalhos.

Além dos testes laboratoriais, testes in vivo foram realizados por alguns autores para avaliar a propriedade de liberação de flúor dos cimentos de ionômero de vidro. KoCH; HATIBOVIC-KOFMAN 37 e HATIBOVIC-KOFMAN; KOCH $^{27}$ realizaram restaurações em crianças pré-escolares e HATTAB et al.29 inseriram discos de cimento de ionômero de vidro em aparelhos removíveis que seriam utilizados por indivíduos durante a noite. Através da coleta de amostras de saliva 
não estimulada antes e após o tratamento pôde-se avaliar a liberação de flúor dos materiais. 


\section{2 - Dos Resultados}

Após análise e comparação dos valores totais ou cumulativos registrados para os 8 materiais testados nos períodos de 24 horas, 7 dias e 28 dias, certos aspectos merecem ser destacados e comentados.

Em todos os períodos de leitura o Vidrion C e XR Ionomer foram os dois materiais que liberaram as maiores quantidades de flúor, destacando-se positivamente dos demais materiais testados. No período de 24 horas, O Vidrion C alcançou um valor total de $3,693 \mu \mathrm{g} \mathrm{F}^{-} / \mathrm{mm}^{2}$ e o XR Ionomer, 3,340 $\mu \mathrm{g} \mathrm{F}^{-} / \mathrm{mm}^{2}$. No período de 7 dias registrou-se um valor

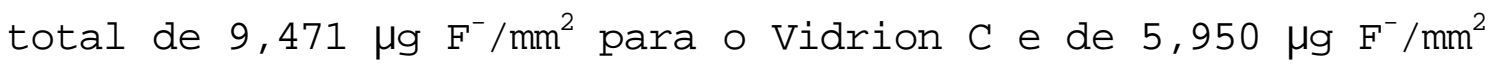
para $O \mathrm{XR}$ Ionomer e no período de 28 dias, $\mathrm{XR}$ Ionomer passou a apresentar um valor total de liberação de flúor

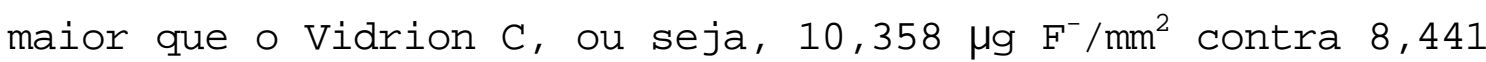
$\mu \mathrm{g} \mathrm{F}^{-} / \mathrm{mm}^{2}$. Os outros materiais, nominalmente Ketac-Bond, Shofu I, Vitrebond, Ketac-Cem e GC Fuji I, ocuparam uma posição intermediária, liberando uma quantidade total de flúor entre 0,621 e 1,671 $\mu \mathrm{g} \mathrm{F}^{-} / \mathrm{mm}^{2}$ no período de 24 horas, entre 1,381 e $3,577 \mu \mathrm{F}^{-} / \mathrm{mm}^{2}$ no período de 7 dias e no

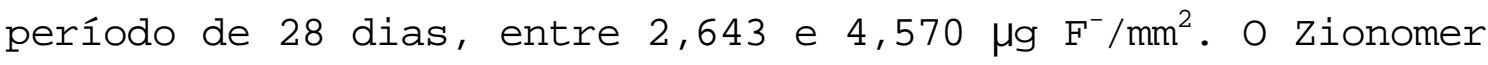
pó/líquido sempre ocupou a última colocação, liberando um quantidade total de $0,043 \mu \mathrm{g} \mathrm{F}^{-} / \mathrm{mm}^{2}$ no período de 24

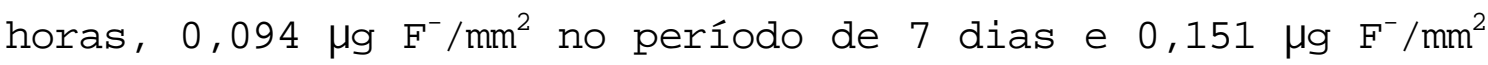


no período de 28 dias, destacando-se de maneira negativa dos demais materiais.

De acordo com hATtAB et al. 29 quantidades mínimas de flúor $(0,02-0,12 \mathrm{ppm})$ em uma solução desmineralizante são capazes de reduzir a taxa de solubilidade do esmalte e a perda de mineral da lesão de esmalte. HÖRSTED-BINDSLEV; LARSEN ${ }^{31}$, em outras palavras, afirmaram que concentrações de flúor entre 0,02 e 0,12 ppm têm um efeito anticariogênico durante as atividades de desmineralização. Contudo, deve ser lembrado que os valores analisados até o momento representam a somatória das médias registradas em cada intervalo de leitura dos três períodos estudados e estes valores totais ou cumulativos não oferecem subsídios para a análise das características comportamentais durante o tempo, isto é, do padrão de liberação de flúor dos materiais. Esta análise é ainda mais importante clinicamente, porque um dado material pode apresentar um alto valor total, todavia este valor pode representar uma liberação vigorosa de flúor nos períodos iniciais, talvez acima do que o esmalte seja capaz de incorporar, e uma liberação continuada pequena, o que segundo CRANFIELD; KUHN; WINTER ${ }^{5}$, DESCHEPPER et al. 11 e FORSTEN ${ }^{18}$ parece ter valor relativo.

Analisando-se primeiramente a quantidade de liberação de flúor em cada intervalo de leitura dos três períodos de 
avaliação verifica-se, como já comentado no capítulo de Resultados, que o padrão de liberação de flúor foi semelhante para todos os materiais testados, tanto os cimentantes como os forradores, os quimicamente ativados e os fotoativados. Pôde ser observado um "burst effect" (efeito explosão), onde registrou-se um alto valor de liberação de flúor inicialmente, nos primeiros intervalos de leitura, seguindo-se uma queda acentuada e/ou gradual de acordo com cada material e com tendência a valores constantes com o transcorrer do tempo. Esse padrão de liberação de flúor apresenta-se compatível com a literatura consultada e, mesmo naqueles trabalhos de longa duração , onde os períodos de avaliação atingem de 1 a 21/2 anos, os diferentes cimentos de ionômero de vidro testados apresentam uma liberação de flúor continuada menor que a inicial, entretanto com tendência a valores constantes. A única exceção presente na literatura onde encontram-se resultados diferentes é o trabalho realizado por CAUSTON $^{3}$ em 1981. Nele o autor afirma que a liberação de flúor do cimento de ionômero de vidro testado cessou após 6 meses de exposição à água, indicando que somente os íons flúor liberados da matriz durante a reação de endurecimento estão disponíveis para a proteção da estrutura dentária adjacente. 
Nos três períodos de avaliação as quantidades de flúor liberado pelos diferentes materiais variaram grandemente durante os primeiros intervalos de leitura, porém as diferenças tornaram-se menores ao longo do tempo. Analisando-se secundariamente cada material, notam-se certas variações nas características comportamentais que podem ter implicações clínicas diferentes.

O Vidrion C apresentou uma alta liberação de flúor nos períodos iniciais, principalmente durante as primeiras horas, e uma liberação continuada gradativamente menor.

O XR Ionomer, diferentemente do Vidrion C, apresentou uma alta liberação de flúor nos períodos iniciais, principalmente durante a primeira semana, e uma liberação continuada relativamente menor, todavia constante.

Os materiais Ketac-Bond, Ketac-Cem e GC Fuji I apresentaram, guardadas as devidas proporções, caracteristicas comportamentais semelhantes ao Vidrion C podendo ser utilizados, clinicamente, para adequação do meio. Já o Shofu I, o Vitrebond e o Zionomer pó/líquido apresentaram características comportamentais semelhantes ao XR Ionomer.

Segundo DESCHEPPER et al. ${ }^{11}$, a significância clínica do padrão de liberação de flúor não está claramente 
esclarecida e determinada, mas uma comparação dos valores de liberação de flúor ao longo do tempo entre os materiais pode ser de maior interesse terapêtico que a comparação entre os altos valores de liberação inicial.

o principal mecanismo anticariogênico do flúor relaciona-se a sua capacidade de interferir no processo dinâmico de desmineralização e remineralização, fazendo com que o segundo predomine sobre o primeiro. Dessa maneira, ressalta-se a importância de se ter íons flúor constantemente presentes no meio bucal e por isso destaca-se - valor da liberação continuada ao longo do tempo. Os cimentos de ionômero de vidro forradores e cimentantes, apesar de não estarem diretamente expostos ao meio bucal, apresentam potencial anticariogênico. A liberação de flúor às margens do preparo pelos ionômeros forradores é possível devido à diferença entre os valores dos coeficients de expansão térmica linear dos materiais restauradores e da estrutura dentária, o que permite a formação de um microespaço através do qual o flúor é conduzido para o exterior por pressão hidrostática do fluido pulpar. Os ionômeros cimentantes liberam flúor através da linha de cimentação exposta ao meio bucal e presente entre a prótese ou acessório ortodôntico e a estrutura dentaria. A quantidade terapêtica mínima de flúor para a prevenção de cárie dentária não está, até o momento, totalmente 
estabelecida, contudo diante dos resultados obtidos, o único material testado que provavelmente não apresenta valor terapêutico quanto à prevenção de cárie é o Zionomer pó/líquido, pois nos três períodos de avaliação liberou, inicialmente e ao longo do tempo, quantidades muito pequenas de flúor. Uma explicação para este comportamento foi dada por DESCHEPPER et al.11 em seu trabalho, onde relatam que o material zionomer pó/líquido apresenta-se tamponado, o que pode afetar adversamente sua propriedade de liberação de flúor. Os demais materiais apresentaram valores significantes e maiores de liberação de flúor e, de uma maneira geral, todos podem apresentar potencial anticariogênico. Torna-se difícil e não precisa a realização de uma classificação ou ordenação do potencial anticariogênico de um grupo de materiais levando-se em conta somente a propriedade de liberação de flúor, pois a performance clínica desses materiais é que vai ditar e estabelecer esse potencial.

De acordo com a literatura, a liberação de flúor de um cimento de ionômero de vidro depende de uma série de fatores intrínsecos e extrínsecos.

Como fator intrínseco destaca-se a composição química do cimento ${ }^{10}$, relacionada ao conteúdo de flúor presente no componente pó $1,10,11,13,16,17,27,29,31,38,41,47,65$, à forma 
de união e solubilidade dos compostos de flúor do material $12, \mathbf{2 1}, \mathbf{4 7}, \mathbf{5 0 , 6 5}$ e ao conteúdo de sódio presente, pois,

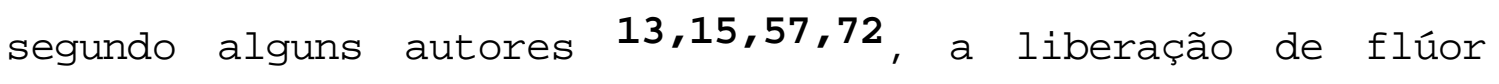
correlaciona-se e é controlada pela concentração de sódio. Apesar de FORSTEN $^{17}$ verificar que quanto maior o conteúdo de flúor de um material maior é a liberação apresentada por ele, DEVLIN et al. ${ }^{13}$, KOMATSU et al. ${ }^{41}$, SHEN; BAN 57 e TVEIT; GJERDET 65 não encontraram uma relação específica entre a porcentagem de flúor presente no componente pó e a quantidade de flúor liberado após manipulação. Outros fatores intrínsecos podem ser mencionados: porosidade do material 11,29,41; solubilidade, que segundo alguns autores 11,17,51 apresenta relação diretamente proporcional à taxa de liberação de flúor; reação de endurecimento ${ }^{1}$; proporção pó/líquido 5, 8, 29, 41, 47, 49,51, geometria da amostra $5,12,24,29$, 72 e tipo e quantidade de resina incorporada aos cimentos de ionômero de vidro fotoativados 50 . A maior quantidade observada de flúor liberado nos períodos iniciais após a manipulação relaciona-se à maior movimentação iônica na massa, o que facilita a liberação de elementos ionicamente ativos como o flúor e, por isso, quanto mais longa a reação de endurecimento de um cimento ionomérico, maior será sua 
liberação de flúor ${ }^{1}$. A proporção pó/líquido apresenta relação inversamente proporcional à taxa de liberação de flúor. No que diz respeito à geometria da amostra, apesar de CRANEIELD; KUHN; WINTER $^{5}$ acreditarem que o flúor liberado advém das porções externa e interna do material - ou seja, quanto maior o volume da amostra maior seria a liberação -, DESCHEPPER et al. ${ }^{12}$, FUKAZAWA; MATSUYA; YAMANE $^{24}$ e WILSON; GROFFMAN; KUHN $^{72}$ afirmam que a liberação de flúor é dependente somente da área de superfície exposta; MOMOI; MCCABE 50 sugerem que a liberação inicial de flúor está relacionada à área de superfície exposta da amostra e a liberação continuada, relacionada ao volume.

Os fatores extrínsecos estão relacionados ao tempo 29,31,48,61 e energia 31 da mistura dos componentes pó e líquido, tipo de mistura 48,67 (manual x mecânica), tempo de $\operatorname{ativação~}^{49}$ (no caso de cimentos ionoméricos fotoativados), proteção superficial $2, \mathbf{2 9}, \mathbf{4 1}$ e acabamento ${ }^{\mathbf{4 1}}$, tempo transcorrido entre a manipulação e a exposição ao meio de armazenagem $\mathbf{3}, \mathbf{2 0 , 2 4}$, tipo de meio de armazenagem $11,14,29,54,65$, seu $\mathrm{pH}^{5}, 15,18,29,53$, temperatura $5,10,29,35$, volume 29, presença de agitação5,24,29 e, ainda, realização de troca ou substituição do meio de armazenagem 
5, 10,24,29,39. Com respeito ao tempo da mistura dos componentes pó e líquido SWIFT $^{61}$ relatou, através dos resultados de seu trabalho, que um menor tempo está relacionado a maior liberação; todavia, dados recentes de MILLER et al.48 registraram pequena e insignificante influência deste fator sobre a liberação de flúor dos cimentos de ionômero de vidro. De acordo com MILLER et al.48 e VERBEECK et al. ${ }^{67}$, cimentos ionoméricos misturados manualmente liberam menos flúor que aqueles misturados mecanicamente. 0 tempo de ativação não influencia significantemente a taxa de liberação de flúor dos cimentos ionoméricos fotoativados 49 . A proteção superficial de corpos de prova de cimentos ionoméricos conferida pelo uso de verniz ou adesivo diminui a taxa de liberação de flúor em até 61-76\% segundo MCKNIGHT-HANES; WHITFORD ${ }^{41}$. De acordo com estes autores o acabamento de corpos de prova previamente protegidos pode aumentar a taxa de liberação dependendo do material em questão. Quanto menor o tempo transcorrido entre a manipulação e a exposição ao meio de armazenagem maior a liberação de flúor, pois segundo certos autores $\mathbf{3 , 2 0 , 2 4}$, menor será o grau de maturação do material e conseqüentemente, maior a sua solubilidade. O tipo ou composição do meio de armazenagem também influencia na taxa 
de liberação de flúor, a qual se apresenta claramente mais alta em água destilada e/ou desionizada que em qualquer outro meio, seja saliva artificial 14,54, saliva humana 53 ou soluções diversas 53 . Segundo REZK-LEGA; ÖGAARD; RÖLI.A 53 , provavelmente uma "camada inibidora" é formada sobre as amostras dos materiais em saliva humana, reduzindo a disponibilidade de flúor, sendo que a absorção de íons fosfato (na forma de $\mathrm{HPO}_{4}{ }^{-2}$ ) e proteínas em $\mathrm{pH}$ neutro pode ser um mecanismo concebível. EL MALLAKH; SARKAR $^{14}$ acreditam que a presença de vários cátions na saliva artificial pode ser responsável por esse fenômeno. Adicionalmente, quanto menor o pH do meio de armazenagem, maior a liberação de flúor, fato que segundo FORSTEN ${ }^{18}$ deve-se à maior solubilidade do material em meio ácido. De acordo com CRANFIELD; KUHN; WINTER $^{5}$, a temperatura do meio de armazenagem tem pouca influência sobre a taxa de liberação de flúor, todavia JoNES et al. 35 observaram relação diretamente proporcional entre temperatura e liberação. A agitação do meio de armazenagem exerce pouca ${ }^{5}$ ou nenhuma ${ }^{24}$ influência sobre a taxa de liberação de flúor. Apesar de FUKAZAWA; MATSUYA; YAMANE 24 notarem pequena influência da troca do meio de armazenagem sobre a liberação de flúor, outros autores $5,10,39$ observaram um aumento na quantidade de flúor liberado conforme aumenta 
a frequiência de troca. Segundo DERKSON; POON; RICHARDSON ${ }^{10}$, espera-se que haja menor liberação de flúor quando o meio de armazenagem não é trocado periodicamente (lei de difusão de Fick), como descrito no capítulo de Discussão da Metodologia.

A natureza do processo que controla a liberação de flúor dos cimentos de ionômero de vidro não está, até o momento, totalmente estabelecida e, por isso, existem várias teorias. Como em certos trabalhos a quantidade cumulativa de flúor liberado foi linear contra a raiz quadrada do tempo, alguns autores $\mathbf{1 0 , 2 4 , 3 0}$ acreditam que a liberação seja controlada pelo fenômeno da difusão. TAY; BRADEN ${ }^{63}$ relatam que possivelmente dois processos estejam envolvidos: um de natureza rápida, representando liberação de superfície e um outro de natureza mais lenta e contínua, representando difusão de volume. KUHN; WILSON$^{39}$ acrescentam a esses dois processos um terceiro, que seria uma difusão através dos poros e fissuras do material. A troca de íons, onde um íon flúor no cimento, por exemplo, é trocado por um grupo hidroxila do meio circundante, é o processo de liberação de flúor postulado por DEVLIN et al. ${ }^{13}$ e DE BARRA et al. 9 . Os íons sódio facilitam a taxa de troca de íons, possivelmente pelo rompimento da matriz do cimento e aumento da mobilidade dos íons ${ }^{13}$. Segundo FUKAZAWA; MATSUYA; YAMANE ${ }^{24}$, o flúor 
tende a liberar-se preferencialmente da matriz do cimento, podendo estar na forma de fluoreto de sódio ${ }^{14}$, fluoreto de alumínio ${ }^{\mathbf{8}}$, fluorfosfato ${ }^{\mathbf{8}}$ ou como um íon flúor ${ }^{13}$.

A liberação de flúor quando incorporado a materiais tais como amálgamas, resinas e outros cimentos é pequena e limitada $1,10,11,16,17,18,19,20,21,22,32,33,34,40,47,50,52$,

$58,59,60,65$, podendo seu efeito terapêtico ser comparado ao de uma única aplicação tópica de flúor ${ }^{16}$.

A efetividade dos cimentos de silicato e de ionômero de vidro na prevenção da cárie dentária é atribuída à contínua liberação de flúor por eles apresentada. Os cimentos de ionômero de vidro, diferentemente dos cimentos de silicato, liberam íons, incluindo o flúor, que não são estruturalmente importantes e, assim, não há interferência negativa nas propriedades físicas e mecânicas do material 8.

Adicionalmente, os cimentos de ionômero de vidro têm a capacidade de absorver o flúor presente na cavidade bucal, oriundo do próprio cimento ou de qualquer outra fonte e novamente liberá-lo; este "efeito esponja" aumenta e torna constante sua efetividade $6,19,27,28,56$. 


\section{7 - Conclusões}

De acordo com a metodologia utilizada neste estudo in vitro pode-se concluir que:

7.1 - quantidades mensuráveis de liberação de flúor foram registradas para todos os materiais testados durante os três períodos de leitura;

7.2 - Vidrion $\mathrm{C}$ e XR Ionomer foram os materiais que apresentaram as maiores quantidades de liberação de flúor; Ketac-Bond, Vitrebond, Ketac-Cem, GC Fuji I e Shofu I ocuparam uma posição intermediária e o Zionomer pó/líquido liberou a menor quantidade de flúor;

7.3 - apesar das quantidades apresentarem-se diferentes, o padrão de liberação de flúor foi semelhante para todos os materiais testados; observou-se um "burst effect" (efeito explosão), com registros de grande liberação de flúor nos primeiros intervalos de leitura, seguindo-se queda acentuada e/ou gradual, de acordo com cada material, tendendo a valores constantes no transcorrer do tempo. 


\section{Referências Bibliográficas*}

1- CARVAlHo, R.M. et al. Padrão de liberação de flúor de cimentos odontológicos - (I) cimentos de ionômero de vidro e de sílico-fosfato. Rev. gaúcha Odont., v.38, n.5, p.346-8, set./out. 1990.

2- CASTRO, G.W. et al. Effect of surface coating on fluoride release from glass ionomer. J.dent.Res., v.72, p.221, Mar. 1993. Special issue./Abstract n.943/

3- CAUSTON, B.E. The physico-mechanical consequences of exposing glass ionomer cements to water during setting. Biomaterials, v.2, p.112-5, Apr. 1981.

4- COOLEY, R.L.; MCCOURT, J.W. Fluoride - releasing removable appliances. Quintessence Int.' v.22, n.4, p.299-302, Apr. 1991.

\footnotetext{
* Normas recomendadas para uso no âmbito da Universidade de São Paulo, com base no documento "Referências Bibliográficas: exemplos", emanado do Conselho Supervisor do Sistema Integrado de Bibliotecas da USP, em reunião de 20 de setembro de 1990.
} 
5- CRANFIELD, M.; KUHN, A.T.; WINTER, G.B. Factors relating to the rate of fluoride - ion release from glass-ionomer cement. J.Dent., v.10, n.4, p.333-41, Dec. 1982 .

6- CREANOR, S.L. et al. Fluoride uptake and release characteristics of glass ionomer cements. Caries Res., v.28, n.5, p.322-8, 1994.

7- CRISP, S.; WILSON, A.D. Reactions in glass ionomer cements: I- decomposition of the powder. J.dent.Res., v.53, n.6, p.1408-13, Nov./Dec. 1974.

8- CRISP, S.; LEWIS, B.G.; WILSON, A.D. Glass ionomer cements: chemistry of erosion. J.dent. Res., v.55, n.6, p.1032-41, Nov./Dec. 1976.

9- DE BARRA, E. et al. The mechanism of fluoride release from glass (ionomer) polyalkenoate cements. J.dent. Res., v.74, p.833, Mar. 1995. Special issue./Abstract n.92/ 


$$
\begin{aligned}
& \text { 10- DERKSON, G.D.; POON, P.J.; RICHARDSON, A.S. } \\
& \text { Fluoride release from a silicophosphate cement } \\
& \text { with added fluoride J.dent.Res., v.61, n.5, } \\
& \text { p.660-4, May } 1982 .
\end{aligned}
$$

11- DESCHEPPER, E.J. et al. Fluoride release from light -cured liners. Amer.J.Dent., v.3, n.3, p.97-100, June 1990.

12- DESCHEPPER, E.J. et al. A comparative study of fluoride release from glass-ionomer cements. Quintessence Int., v.22, n.3, p.215-20, Mar. 1991 .

13- DEVLIN, A.J. et al. Fluoride ion release from glass-ionomer cements. J. dent. Res., v.74, p.833, Mar.1995. Special issue./Abstract n.91/

14- EL MALLAKH, B.F.; SARKAR, N.K. Fluoride release from glass-ionomer cements in de - ionized water and artificial saliva. Dent. Mat., v.6, n.2, p.118-22, Apr. 1990. 
15- FORSS, H. Release of fluoride and other elements from light-cured glass ionomers in neutral and acidic conditions. J. dent. Res., v.72, n.8, p.1257-62, Aug. 1993.

16- FORSTEN, L. Fluoride release from a fluoride containing amalgam and two luting cements. Scand. J. dent. Res., V.84, n.5, p.348-50, 1976.

17- FORSTEN, L. Fluoride release from a glass ionomer cement. Scand. J. dent. Res., V.85, n.6, p.503-4, sept. 1977.

18- FORSTEN, L. Short- and long- term fluoride release from glass ionomers and other fluoride - containing filling materials in vitro. Scand. J. dent. Res., v.98, p.179-85, 1990.

19- FORSTEN, L. Fluoride release and uptake by glass ionomers. Scand. J. dent. Res., v.99, n.3, p.241-5, June 1991. 
20- FORSTEN,L. Short- and long- term fluoride release from glass ionomer based liners. Scand. J. dent. Res., v.99, n.4, p.340-2, Aug. 1991.

21- FORSTEN,L.; PAUNIO, I.K. Fluoride release by silicate cements and composite resins. Scand. J. dent. Res., v.80, p.515-9, 1972.

22- FORSTEN, L.; PAUNIO, I.K. Fluoride release from varnish- coated silicates and from cavity liners and fissure sealants. Scand. J. dent. Res., v.81, p.513-7, 1973.

23- FORSTEN, L.; VÄLIAHO, M.-L. Transverse and bond strength of restorative resins. Acta odont. scand., v.29, n.5, p.527-37, June 1971.

24- FUKAZAWA, M.; MATSUYA, S.; YAMANE, M. Mechanism for erosion of glass-ionomer cements in an acidic buffer solution. J. dent. Res., v.66, n.12, p.1770-4, Dec. 1987. 


\begin{abstract}
25- GARCIA-GODOY, F.; CHAN, D.C.N. Long-term fluoride release from glass ionomer - lined amalgam restorations. Amer. J.Dent., v.4, n.5, p.223-5, Oct. 1991 .
\end{abstract}

26- GARIB, T.M. Avaliação in vitro da atividade antimicrobiana de cimentos de ionômero de vidro restauradores, sobre o streptococcus mutans da cepa GS-5. Bauru, 1991. 136p. Dissertação (Mestrado) - Faculdade de Odontologia de Bauru, Universidade de São Paulo.

27- HATIBOVIC - KOFMAN, S.; KOCH, G. Fluoride release from glass ionomer cement in vivo and in vitro. Swed. dent. J., v.15, p.253-8, 1991.

28-HATIBOVIC - KOFMAN, S.; KOCH, G.; EKSTRAND, J. Glass ionomer as a rechargeable fluoride system. J. dent. Res., V.73, p.134, Mar. 1994. Special issue./Abstract n.260/ 
29- HATTAB, F.N. et al. An in vivo study on the release of fluoride from glass - ionomer cement. Quintessence Int., v.22, n.3, p.221-4, Mar. 1991.

30- HIGUCHI, T. apud MITRA, S.B. 49 p.40.

31- HÖRSTED-BINDSLEV, P.; LARSEN, M.J. Release of fluoride from conventional and metal-reinforced glass-ionomer cements. Scand. J. dent. Res., v.98, n.5, p.451-5, Oct. 1990 .

32- HÖRSTED-BINDSLEV, P.; LARSEN, M.J. Release of fluoride from light cured lining materials. Scand. J. dent. Res., v.99, n.1, p.86-8, Feb. 1991.

33- JENSEN, M.E.; WEFEl, J.S.; HAMMESFAHR, P.D. Fluoride- releasing liners: in vitro recurrent caries. Gen. Dent., v.39, n.1, p.12-7, Jan./ Feb. 1991. 
34- JINKS, G.M. Fluoride- impregnated cements and their effect on the activity of interproximal caries. J. Dent. Child, v.30, n.2, p.87-92, 1963.

35- JONES, D.W. et al. Fluoride release from glass ionomer materials at 37 and $21^{\circ} \mathrm{C}$. J. dent. Res., v.66, p.113, Feb. 1987. Special issue./ Abstract n.49/

36- KENT, B.E.; LEWIS, B.G.; WILSON, A.D. The properties of a glass ionomer cement. Brit. dent. J., v.135, n.7, p.322-6, Oct. 1973.

37- KOCH, G.; HATIBOVIC- KOFMAN, S. Glass ionomer cements as a fluoride release system in vivo. Swed. dent. J., V.14, n.6, p.267-73, Nov. 1990.

38- KOMATSU, H. et al. Fluoride release from various types of glass ionomers. J. dent. Res., v.71, p.135, Mar. 1992. Special issue./Abstract n.234/ 
39- KUHN, A.T.; WILSON, A.D. The dissolution mechanisms of silicate and glass-ionomer dental cements. Biomaterials, v.6, p.378-82, Nov. 1985.

40- MCCOURT, J.W.; COOLEY, R.L.; HUDDLESTON, A.M. Fluoride release from fluoride - containing liners/bases. Quintessence Int., v.21, n.1, p.41-5, Jan. 1990 .

41- MCKNIGHT- HANES, C.; WHITFORD, G.M. Fluoride release from three glass ionomer materials and the effects of varnishing with or without finishing. Caries Res., v.26, p.345-50, 1992.

42- MALDONADO, A.; SWARTZ, M.L.; PHILLIPS, R.W. An in vitro study of certain properties of a glass ionomer cement. J. Amer. dent. Ass., v.96, p.785-91, May 1978.

43- MANDERS, C.A.; GARCIA-GODOY, F.; BARNWELL, G.M. Effect of a copal varnish, ZOE or glass ionomer cement bases on microleakage of amalgam restorations. Amer. J. Dent., v.3 n.2, p.63-6, Apr.1990. 
44- MARTINS, L.R.M. Liberação de flúor de restaurações com cimentos de ionômero de vidro e sua incorporação no esmalte dentário humano submetido a ciclagem de desmineralização e remineralização. Bauru, 1991. 74p. Tese (Doutorado) Faculdade de Odontologia de Bauru, Universidade de São Paulo.

45- MEIRA, S.T. Avaliação da liberação de $\mathrm{F}^{-}$de um cimento de ionômero de vidro para forramento, sob restaurações de resina composta e amálgama. Bauru, 1993. 126p. Dissertação (Mestrado) Faculdade de Odontologia de Bauru, Universidade de São Paulo.

46- MELLBERG, J.R.; RIPA, L.W. Fluoride in preventive dentistry-theory and clinical applications. Chicago, Quintessence, 1983.

47- MERYON, S.D.; SMITH, A.J. A comparison of fluoride release from three glass ionomer cements and a polycarboxylate cement. Int. Endod. J., v.17, n.1, p.16-24, 1984. 
48- MILLER, B.H. et al. Effect of glass ionomer manipulation on early fluoride release. Amer. J. Dent., v.8, n.4, p.182-6, Aug. 1995.

49- MITRA, S.B. In vitro fluoride release from a light-cured glass-ionomer liner/base. J. dent. Res., v.70, n.1, p.75-8, Jan. 1991.

50- MOMOI, Y.; MCCABE, J.F. Fluoride release from light-activated glass ionomer restorative cements. Dent. Mat., v.9, n.3, p.151-4, May 1993.

51- MUZYNSKI, B.L. et al. Fluoride release from glass ionomers used as luting agents. J.prosth. Dent., v.60, n.1, p.41-4, July 1988.

52- PHILLIPS, R.W.; SWARTZ, M.L. Effect of certain restorative materials on solubility of enamel. J.Amer. dent. Ass., v.54, p.623-36, May 1957.

53- REZK-LEGA, F.; ÖGAARD, B.; RÖLLA, G. Availability of fluoride from glass-ionomer luting cements in human saliva. Scand. J. dent. Res., v.99, n.1, p.60-3, Feb. 1991. 
54- RYU, J.H.; LEE, J.S.; KIM, K.N. Fluoride release from restorative glass- ionomers into deionized water and artificial saliva. J. dent. Res., v.74, p.992, Mar. 1995. Special issue./ Abstract n.0-35/

55- SCHWARTZ, N.L. et al. Unserviceable crowns and fixed partial dentures: life - span and causes for loss of serviceability. J. Amer. dent. Ass., v.81, p.1395-401, Dec. 1970.

56- SEPPÄ, L.; FORSS, H.; ÖGAARD, B. The effect of fluoride application on fluoride release and the antibacterial action of glass ionomers. J. dent. Res., v.72, n.9, p.1310-4, Sept. 1993.

57-SHEN, C.; BAN, S. Effect of composition in fluoride release from glass ionomer cements. J. dent. Res., v.69, p.343, 1990. Special issue./Abstract n. 1874/

58- STANNARD, J.G.; VIAZIS, A.D. Effect of fluoride from dental materials on acid demineralization of enamel. Oper. Dent., v.13, p.58-65, 1988. 


$$
\begin{aligned}
& \text { 59- STRICKLAND, S.; RETIEF, D.H.; RUSSELL, C.M. } \\
& \text { Shear bond strengths to dentin and fluoride } \\
& \text { release from fluoride - containing liners. } \\
& \text { Amer. J. Dent., v.3, n.6, p.259-63, Dec. } 1990 .
\end{aligned}
$$

60- SWARTZ, M.L.; PHILLIPS, R.W.; CLARK, H.E. Long term $F$ release from glass ionomer cements. J. dent. Res., v.63, n.2, p.158-60, Feb. 1984.

$$
\begin{aligned}
& \text { 61- SWIFT, E.J. Effect of mixing time on fluoride } \\
& \text { release from a glass ionomer cement. Amer. } \\
& \text { J. Dent., v.1, p.132-4, } 1988 .
\end{aligned}
$$
62- SWIFT JR., E.J. Fluoride - containing restorative materials. Clin. Prev. Dent., v.10, n.6, p.19- 24, Nov./Dec. 1988.
63- TAY, W.M.; BRADEN, M. Fluoride ion diffusion from polyalkenoate (glass-ionomer) cements. Biomaterials, v.9, p.454-6, sept. 1988.




$$
\begin{aligned}
& \text { 64- THORNTON, J.B.; RETIEF, D.H., BRADLEY, E.L. } \\
& \text { Fluoride release from and tensile bond } \\
& \text { strength of Ketac-Fil and Ketac-Silver to } \\
& \text { enamel and dentin. Dent. Mat., v.2, n.6, p.241- } \\
& \text { 5, Dec. } 1986 .
\end{aligned}
$$

65- TVEIT, A.B.; GJERDET, N.R. Fluoride release from a fluoride - containing amalgam, a glass ionomer cement and a silicate cement in artificial saliva. J. oral Rehab., v.8, n.3, p.237-41, May 1981.

$$
\begin{aligned}
& \text { 66-VALK, J.W.P.; DAVIDSON, C.L. The relevance of } \\
& \text { controlled fluoride release with bonded } \\
& \text { orthodontic appliances. J. Dent., v.15, n.6, } \\
& \text { p.257-60, Dec. } 1987 .
\end{aligned}
$$

67- VERBEECK, R.M.H. et al. The short-term fluoride release of a hand-mixed vs capsulated system of a restorative glass-ionomer cement. J.dent. Res., v.72, n.3, p.577-81, Mar. 1993.

$$
\begin{aligned}
& \text { 68- VOLKER, J.; BEKARIS, B.; MELILLO, S. apud } \\
& \text { PHILLIPS, R.W.; SWARTZ, M.L. } 52 \text { p.5. }
\end{aligned}
$$




$$
\begin{aligned}
& \text { 69- WHARTON, H.V. apud FORSTEN, L.; PAUNIO, I.K. } 21 \\
& \text { P.8. } \\
& \text { 70- WILSON, A.D.; BATCHELOR, R.F. Dental silicate } \\
& \text { cements -I: the chemistry of erosion. J. } \\
& \text { dent. Res., v.46, n.5, p.1075-85, Sept./Oct. } \\
& \text { 1967. }
\end{aligned}
$$
71-WILSON, A.D.; KENT, B.E. The glass - ionomer cement: a new translucent dental filling materials. J. appl. Chem. Biotechnol., v.21, p.313, 1971 .

72- WILSON, A.D.; GROFFMAN, D.M.; KUHN, A.T. The release of fluoride and other chemical species from a glass-ionomer cement. Biomaterials, v.6, p.431-3, Nov. 1985.

73- WOOLFORD, M.J.; GRIEVE, A.R. Release of fluoride from glass polyalkenoate (ionomer) cement subjected to radiant heat. J. Dent., v.23, n.4, p.233-7, Aug. 1995. 


\section{Abstract}

The objective of the present in vitro study was to evaluate and compare the pattern and the quantity of fluoride release of lining and luting glass ionomer cements after 24 hours, 7 days and 28 days in de-ionized water. Six disc-shaped specimes were made for each material and for each reading period. After the initial hardening reaction, they were pierced and suspended in plastic containers with $18 \mathrm{~mL}$ of de-ionized water. Readings were carried out every six hours in the 24-hour period, every 24 hours in the 7day period, and every 7 days in the 28-day period, when $2 \mathrm{~mL}$ of TISAB III buffer solution was added. The concentration of fluoride ions in solution was evaluated through potenciometric readings using an ion analyser device. Vidrion $\mathrm{C}$ and $\mathrm{XR}$ Ionomer showed the highest quantity of fluoride release. Ketac-Bond, Vitrebond, Ketac-Cem, GC Fuji I and Shofu I were intermediary in rank, whereas powder/liquid zionomer released the least quantity of fluoride. However, the pattern of fluoride release was the same to all the tested materials. 


\section{A pêndices}




\section{Apêndices}

Tabela I- Valores da quantidade de flúor liberado no período de 24 horas pelo Ketac-Cem (em $\mu \mathrm{g} \mathrm{F}^{-} / \mathrm{mm}^{2}$ ).

\begin{tabular}{lllllllll}
\hline Espécimes & 1 & 2 & 3 & 4 & 5 & 6 & Média & DP
\end{tabular}

Horas

$\begin{array}{llllllllll}6 & 0,311 & 0,291 & 0,295 & 0,359 & 0,395 & 0,328 & 0,329 & 0,040 \\ 12 & 0,144 & 0,112 & 0,117 & 0,130 & 0,171 & 0,139 & 0,135 & 0,021 \\ 18 & 0,106 & 0,078 & 0,080 & 0,088 & 0,114 & 0,099 & 0,094 & 0,014 \\ 24 & 0,102 & 0,075 & 0,078 & 0,083 & 0,104 & 0,094 & 0,089 & 0,012\end{array}$

Tabela II-Valores da quantidade de flúor liberado no período de 7 dias pelo Ketac-Cem (em $\mu \mathrm{g} \mathrm{F}^{-} / \mathrm{mm}^{2}$ ).

\begin{tabular}{lllllllll}
\hline Espécimes & 1 & 2 & 3 & 4 & 5 & 6 & Média & DP \\
\hline
\end{tabular}

Dias

$10,5860,760 \quad 0,800 \quad 0,580 \quad 0,6440,5950,6600,095$

$20,2430,3050,3050,2210,240 \quad 0,1870,250 \quad 0,046$

$30,1710,2030,2000,1550,1810,1490,1760,022$

$4 \quad 0,1310,1580,1590,1200,1190,1050,1320,022$

$5 \quad 0,0630,0920,0970,0660,0710,0630,0750,015$

$6 \quad 0,0650,0800,0820,0580,0740,0630,0700,009$

$7 \quad 0,0470,0590,0730,0560,0580,0490,0570,009$ 
Tabela III- Valores da quantidade de flúor liberado no período de 28 dias pelo Ketac-Cem (em
$\mu g \mathrm{~F}^{-} / \mathrm{mm}^{2}$ ).

\begin{tabular}{lllllllll}
\hline Espécimes & 1 & 2 & 3 & 4 & 5 & 6 & Média & DP
\end{tabular}

Dias

\begin{tabular}{llllllllll}
7 & 2,315 & 1,867 & 2,200 & 2,315 & 1,679 & 1,737 & 2,018 & 0,291 \\
14 & 1,244 & 0,941 & 0,926 & 0,997 & 0,716 & 0,764 & 0,931 & 0,187 \\
21 & 0,528 & 0,467 & 0,538 & 0,440 & 0,362 & 0,388 & 0,453 & 0,071 \\
28 & 0,295 & 0,214 & 0,386 & 0,233 & 0,139 & 0,141 & 0,234 & 0,094 \\
\hline
\end{tabular}


Tabela IV- Valores da quantidade de flúor liberado no período de 24 horas pelo GC Fuji I (em $\mu g \mathrm{~F}^{-}$ $\left./ \mathrm{mm}^{2}\right)$

\begin{tabular}{lllllllll}
\hline Espécimes & 1 & 2 & 3 & 4 & 5 & 6 & Média & DP
\end{tabular}

Horas

$\begin{array}{llllllllll}6 & 0,395 & 0,363 & 0,451 & 0,347 & 0,395 & 0,373 & 0,387 & 0,036 \\ 12 & 0,099 & 0,093 & 0,119 & 0,086 & 0,101 & 0,099 & 0,099 & 0,011 \\ 18 & 0,065 & 0,064 & 0,081 & 0,065 & 0,071 & 0,077 & 0,070 & 0,007 \\ 24 & 0,063 & 0,059 & 0,073 & 0,057 & 0,065 & 0,067 & 0,064 & 0,005\end{array}$

Tabela V- Valores da quantidade de flúor liberado no período de 7 dias pelo GC Fuji I (em $\mu g$ F $^{-}$ $/ \mathrm{mm}^{2}$ ).

\begin{tabular}{lllllllll}
\hline Espécimes & 1 & 2 & 3 & 4 & 5 & 6 & Média & DP \\
\hline
\end{tabular}

Dias

$\begin{array}{lllllllllll}1 & 0,790 & 0,680 & 0,829 & 0,747 & 0,719 & 0,797 & 0,760 & 0,055 \\ 2 & 0,265 & 0,213 & 0,257 & 0,211 & 0,203 & 0,211 & 0,226 & 0,026 \\ 3 & 0,162 & 0,131 & 0,158 & 0,134 & 0,122 & 0,113 & 0,136 & 0,019 \\ 4 & 0,118 & 0,090 & 0,098 & 0,088 & 0,087 & 0,089 & 0,095 & 0,011 \\ 5 & 0,094 & 0,067 & 0,077 & 0,071 & 0,080 & 0,076 & 0,077 & 0,009 \\ 6 & 0,053 & 0,043 & 0,048 & 0,038 & 0,041 & 0,036 & 0,043 & 0,006 \\ 7 & 0,046 & 0,040 & 0,042 & 0,039 & 0,044 & 0,043 & 0,042 & 0,002\end{array}$


Tabela VI- Valores da quantidade de flúor liberado no período de 28 dias pelo GC Fuji I (em $\left.\mu \mathrm{g} \quad \mathrm{F}^{-} / \mathrm{mm}^{2}\right)$

\begin{tabular}{lllllllll}
\hline Espécimes & 1 & 2 & 3 & 4 & 5 & 6 & Média & DP
\end{tabular}

Dias

$\begin{array}{llllllllll}7 & 2,069 & 2,475 & 2,171 & 1,592 & 1,650 & 1,809 & 1,961 & 0,339 \\ 14 & 0,718 & 0,844 & 0,713 & 0,428 & 0,518 & 0,583 & 0,634 & 0,152 \\ 21 & 0,337 & 0,411 & 0,418 & 0,268 & 0,262 & 0,310 & 0,334 & 0,067 \\ 28 & 0,168 & 0,213 & 0,187 & 0,111 & 0,124 & 0,136 & 0,156 & 0,039\end{array}$


Tabela VII- Valores da quantidade de flúor liberado no período de 24 horas pelo shofu I (em $\left.\mu \mathrm{g} \quad \mathrm{F}^{-} / \mathrm{mm}^{2}\right)$.

\begin{tabular}{lllllllll}
\hline Espécimes & 1 & 2 & 3 & 4 & 5 & 6 & Média & DP
\end{tabular}

Horas

$\begin{array}{llllllllll}6 & 0,654 & 0,525 & 0,449 & 0,504 & 0,739 & 0,627 & 0,583 & 0,108 \\ 12 & 0,230 & 0,188 & 0,161 & 0,182 & 0,250 & 0,198 & 0,201 & 0,032 \\ 18 & 0,122 & 0,100 & 0,081 & 0,092 & 0,134 & 0,107 & 0,106 & 0,019 \\ 24 & 0,092 & 0,073 & 0,058 & 0,067 & 0,092 & 0,080 & 0,077 & 0,013\end{array}$

Tabela VIII- Valores da quantidade de flúor liberado no período de 7 dias pelo shofu I (em $\mu g \mathrm{~F}^{-}$ $\left./ \mathrm{mm}^{2}\right)$.

\begin{tabular}{lllllllll}
\hline Espécimes & 1 & 2 & 3 & 4 & 5 & 6 & Média & DP \\
\hline
\end{tabular}

Dias

$\begin{array}{lllllllllll}1 & 1,664 & 1,737 & 1,954 & 1,968 & 1,462 & 1,679 & 1,744 & 0,192 \\ 2 & 0,585 & 0,570 & 0,563 & 0,628 & 0,444 & 0,473 & 0,543 & 0,070 \\ 3 & 0,357 & 0,343 & 0,341 & 0,394 & 0,269 & 0,285 & 0,331 & 0,046 \\ 4 & 0,227 & 0,205 & 0,204 & 0,242 & 0,165 & 0,171 & 0,202 & 0,030 \\ 5 & 0,163 & 0,159 & 0,159 & 0,195 & 0,136 & 0,143 & 0,159 & 0,020 \\ 6 & 0,134 & 0,129 & 0,131 & 0,158 & 0,112 & 0,119 & 0,130 & 0,015 \\ 7 & 0,145 & 0,140 & 0,138 & 0,155 & 0,109 & 0,113 & 0,133 & 0,018\end{array}$


Tabela IX-Valores da quantidade de flúor liberado no período de 28 dias pelo shofu I (em $\mu g \mathrm{~F}^{-}$ $\left./ \mathrm{mm}^{2}\right)$

\begin{tabular}{lllllllll}
\hline Espécimes & 1 & 2 & 3 & 4 & 5 & 6 & Média & DP
\end{tabular}

Dias

$\begin{array}{llllllllll}7 & 1,292 & 1,490 & 2,518 & 2,576 & 1,311 & 1,548 & 1,789 & 0,595 \\ 14 & 0,267 & 0,314 & 0,557 & 0,518 & 0,284 & 0,343 & 0,380 & 0,124 \\ 21 & 0,187 & 0,217 & 0,360 & 0,362 & 0,182 & 0,231 & 0,256 & 0,082 \\ 28 & 0,185 & 0,187 & 0,294 & 0,297 & 0,150 & 0,191 & 0,217 & 0,062\end{array}$


Tabela X-Valores da quantidade de flúor liberado no período de 24 horas pelo Vidrion C (em $\left.\mu \mathrm{g} \quad \mathrm{F}^{-} / \mathrm{mm}^{2}\right)$

\begin{tabular}{lllllllll}
\hline Espécimes & 1 & 2 & 3 & 4 & 5 & 6 & Média & DP
\end{tabular}

Horas

$\begin{array}{llllllllll}6 & 1,925 & 2,055 & 2,764 & 2,648 & 2,489 & 2,011 & 2,315 & 0,361 \\ 12 & 0,614 & 0,599 & 0,810 & 0,761 & 0,660 & 0,569 & 0,668 & 0,096 \\ 18 & 0,317 & 0,320 & 0,463 & 0,434 & 0,381 & 0,340 & 0,375 & 0,061 \\ 24 & 0,278 & 0,304 & 0,424 & 0,376 & 0,340 & 0,281 & 0,333 & 0,057\end{array}$

Tabela XI- Valores da quantidade de flúor liberado no período de 7 dias pelo Vidrion $\mathrm{C}$ (em $\mu \mathrm{g} \mathrm{F}^{-}$ $\left./ \mathrm{mm}^{2}\right)$

\begin{tabular}{lllllllll}
\hline Espécimes & 1 & 2 & 3 & 4 & 5 & 6 & Média & DP \\
\hline
\end{tabular}

Dias

$15,9775,0655,4275,268 \quad 4,7184,573 \quad 5,171 \quad 0,509$

$21,8091,4761,5481,4301,2881,2421,4650,203$

$31,0230,9000,8910,8830,8100,7930,8830,081$

$4 \quad 0,7920,7030,6870,6320,6150,6210,6750,067$

$5 \quad 0,6570,5380,5050,4620,450 \quad 0,4540,5110,079$

$6 \quad 0,4760,4180,3990,3890,4040,3960,4130,032$

$7 \quad 0,4150,370 \quad 0,3430,3140,3280,3370,3510,036$ 
Tabela XII- Valores da quantidade de flúor liberado no

$$
\begin{aligned}
& \text { período de } 28 \text { dias pelo Vidrion C (em } \\
& \mu \mathrm{g} \mathrm{F}^{-} / \mathrm{mm}^{2} \text { ). }
\end{aligned}
$$

\begin{tabular}{lllllllll}
\hline Espécimes & 1 & 2 & 3 & 4 & 5 & 6 & Média & DP
\end{tabular}

Dias

$\begin{array}{llllllllll}7 & 4,559 & 4,530 & 5,412 & 6,121 & 5,340 & 5,137 & 5,183 & 0,595 \\ 14 & 1,174 & 1,447 & 1,650 & 1,910 & 1,852 & 1,664 & 1,616 & 0,271 \\ 21 & 0,647 & 0,838 & 1,010 & 1,201 & 1,142 & 0,974 & 0,968 & 0,203 \\ 28 & 0,437 & 0,541 & 0,784 & 0,770 & 0,794 & 0,716 & 0,673 & 0,149\end{array}$


Tabela XIII- Valores da quantidade de flúor liberado no período de 24 horas pelo Ketac-Bond (em

$\left.\mu \mathrm{g} \quad \mathrm{F}^{-} / \mathrm{mm}^{2}\right)$

\begin{tabular}{lllllllll}
\hline Espécimes & 1 & 2 & 3 & 4 & 5 & 6 & Média & DP
\end{tabular}

Horas

$61,0041,1760,961 \quad 1,0780,8580,111 \quad 1,0310,114$

$120,3210,3440,2980,2920,2360,3150,3010,036$

$180,1690,1840,1650,1630,1500,1970,1710,016$

$240,1680,1780,1650,1580,1450,1940,1680,016$

Tabela XIV- Valores da quantidade de flúor liberado no período de 7 dias pelo Ketac-Bond (em $\left.\mu \mathrm{g} \quad \mathrm{F}^{-} / \mathrm{mm}^{2}\right)$

\begin{tabular}{lllllllll}
\hline Espécimes & 1 & 2 & 3 & 4 & 5 & 6 & Média & DP \\
\hline
\end{tabular}

Dias

$11,8381,8231,6062,1131,9681,9971,890 \quad 0,176$

$2 \quad 0,6540,5610,4690,6570,6680,6110,6030,076$

$30,3720,3140,300 \quad 0,4040,4210,3820,3650,048$

$4 \quad 0,2620,2730,2730,3330,3140,2780,2880,028$

$50,1590,1520,1550,1940,1850,1580,1670,017$

$60,1460,1410,1200,1560,1760,1480,1470,018$

$7 \quad 0,1180,1050,1030,1320,1170,1070,1130,010$ 
Tabela XV- Valores da quantidade de flúor liberado no período de 28 dias pelo Ketac-Bond (em $\left.\mu g \quad \mathrm{~F}^{-} / \mathrm{mm}^{2}\right)$.

\begin{tabular}{lllllllll}
\hline Espécimes & 1 & 2 & 3 & 4 & 5 & 6 & Média & DP \\
\hline
\end{tabular}

Dias

$\begin{array}{llllllllll}7 & 2,229 & 2,156 & 2,489 & 3,111 & 2,677 & 3,242 & 2,650 & 0,449 \\ 14 & 0,848 & 0,842 & 0,941 & 1,273 & 1,022 & 1,344 & 1,045 & 0,215 \\ 21 & 0,492 & 0,483 & 0,547 & 0,680 & 0,564 & 0,668 & 0,572 & 0,084 \\ 28 & 0,249 & 0,252 & 0,294 & 0,343 & 0,278 & 0,396 & 0,302 & 0,057\end{array}$


Tabela XVI- Valores da quantidade de flúor liberado no período de 24 horas pelo Vitrebond(em $\left.\mu \mathrm{g} \quad \mathrm{F}^{-} / \mathrm{mm}^{2}\right)$

\begin{tabular}{lllllllll}
\hline Espécimes & 1 & 2 & 3 & 4 & 5 & 6 & Média & DP
\end{tabular}

Horas

$\begin{array}{llllllllll}6 & 0,661 & 0,433 & 0,544 & 0,466 & 0,731 & 0,389 & 0,537 & 0,134 \\ 12 & 0,205 & 0,111 & 0,152 & 0,129 & 0,195 & 0,110 & 0,150 & 0,041 \\ 18 & 0,117 & 0,061 & 0,079 & 0,073 & 0,108 & 0,064 & 0,083 & 0,023 \\ 24 & 0,121 & 0,066 & 0,085 & 0,076 & 0,113 & 0,070 & 0,088 & 0,023\end{array}$

Tabela XVII- Valores da quantidade de flúor liberado no período de 7 dias pelo Vitrebond (em $\left.\mu \mathrm{g} \quad \mathrm{F}^{-} / \mathrm{mm}^{2}\right)$.

\begin{tabular}{lllllllll}
\hline Espécimes & 1 & 2 & 3 & 4 & 5 & 6 & Média & DP \\
\hline
\end{tabular}

Dias

$\begin{array}{lllllllllll}1 & 1,650 & 1,133 & 1,048 & 0,831 & 1,090 & 1,106 & 1,143 & 0,271 \\ 2 & 0,402 & 0,317 & 0,289 & 0,260 & 0,304 & 0,282 & 0,309 & 0,049 \\ 3 & 0,250 & 0,213 & 0,198 & 0,182 & 0,211 & 0,197 & 0,208 & 0,023 \\ 4 & 0,220 & 0,168 & 0,155 & 0,149 & 0,176 & 0,168 & 0,172 & 0,025 \\ 5 & 0,163 & 0,127 & 0,119 & 0,107 & 0,133 & 0,121 & 0,128 & 0,019 \\ 6 & 0,117 & 0,105 & 0,101 & 0,093 & 0,124 & 0,113 & 0,108 & 0,011 \\ 7 & 0,112 & 0,103 & 0,092 & 0,089 & 0,104 & 0,098 & 0,099 & 0,008\end{array}$


Tabela XVIII- Valores da quantidade de flúor liberado no período de 28 dias pelo Vitrebond (em $\left.\mu \mathrm{g} \quad \mathrm{F}^{-} / \mathrm{mm}^{2}\right)$.

\begin{tabular}{lllllllll}
\hline Espécimes & 1 & 2 & 3 & 4 & 5 & 6 & Média & DP
\end{tabular}

Dias

$\begin{array}{llllllllll}7 & 2,778 & 2,171 & 2,142 & 2,446 & 2,504 & 2,750 & 2,465 & 0,272 \\ 14 & 0,984 & 0,773 & 0,710 & 0,738 & 0,816 & 0,796 & 0,802 & 0,096 \\ 21 & 0,616 & 0,459 & 0,519 & 0,505 & 0,449 & 0,600 & 0,524 & 0,069 \\ 28 & 0,527 & 0,415 & 0,422 & 0,417 & 0,307 & 0,360 & 0,408 & 0,073\end{array}$


Tabela XIX- Valores da quantidade de flúor liberado no período de 24 horas pelo XR Ionomer $\left(\right.$ em $\left.\mu g \quad F^{-} / \mathrm{mm}^{2}\right)$.

\begin{tabular}{lllllllll}
\hline Espécimes & 1 & 2 & 3 & 4 & 5 & 6 & Média & DP \\
\hline
\end{tabular}

Horas

\begin{tabular}{llllllllll}
6 & 1,476 & 1,505 & 1,505 & 1,765 & 1,664 & 1,708 & 1,603 & 0,123 \\
12 & 0,763 & 0,794 & 0,803 & 0,958 & 0,877 & 0,900 & 0,849 & 0,074 \\
18 & 0,446 & 0,463 & 0,437 & 0,550 & 0,509 & 0,490 & 0,482 & 0,042 \\
24 & 0,428 & 0,382 & 0,360 & 0,466 & 0,395 & 0,398 & 0,404 & 0,037 \\
\hline
\end{tabular}


Tabela XXII- Valores da quantidade de flúor liberado no período de 24 horas pelo zionomer pó/ líquido (em $\left.\mu \mathrm{g} \mathrm{F}^{-} / \mathrm{mm}^{2}\right)$.

\begin{tabular}{lllllllll}
\hline Espécimes & 1 & 2 & 3 & 4 & 5 & 6 & Média & DP
\end{tabular}

Horas

$\begin{array}{llllllllll}6 & 0,020 & 0,028 & 0,019 & 0,021 & 0,017 & 0,019 & 0,020 & 0,003 \\ 12 & 0,010 & 0,012 & 0,010 & 0,009 & 0,008 & 0,008 & 0,009 & 0,001 \\ 18 & 0,008 & 0,008 & 0,006 & 0,006 & 0,006 & 0,006 & 0,006 & 0,001 \\ 24 & 0,007 & 0,008 & 0,005 & 0,006 & 0,005 & 0,006 & 0,006 & 0,001\end{array}$

Tabela XXII- Valores da quantidade de flúor liberado no período de 7 dias pelo zionomer pó/líquido (em $\mu \mathrm{g} \quad \mathrm{F}^{-} / \mathrm{mm}^{2}$ ).

\begin{tabular}{lllllllll}
\hline Espécimes & 1 & 2 & 3 & 4 & 5 & 6 & Média & DP \\
\hline
\end{tabular}

Dias

$\begin{array}{lllllllllll}1 & 0,031 & 0,042 & 0,032 & 0,030 & 0,022 & 0,026 & 0,030 & 0,006 \\ 2 & 0,020 & 0,027 & 0,017 & 0,019 & 0,014 & 0,015 & 0,018 & 0,004 \\ 3 & 0,012 & 0,017 & 0,013 & 0,020 & 0,012 & 0,012 & 0,014 & 0,003 \\ 4 & 0,011 & 0,014 & 0,009 & 0,011 & 0,008 & 0,009 & 0,010 & 0,002 \\ 5 & 0,007 & 0,010 & 0,007 & 0,008 & 0,006 & 0,007 & 0,007 & 0,001 \\ 6 & 0,006 & 0,008 & 0,006 & 0,007 & 0,006 & 0,006 & 0,006 & 0,001 \\ 7 & 0,006 & 0,008 & 0,007 & 0,007 & 0,006 & 0,006 & 0,006 & 0,001\end{array}$


Tabela XIX- Valores da quantidade de flúor liberado no período de 24 horas pelo XR Ionomer $\left(\right.$ em $\left.\mu g \quad F^{-} / \mathrm{mm}^{2}\right)$.

\begin{tabular}{lllllllll}
\hline Espécimes & 1 & 2 & 3 & 4 & 5 & 6 & Média & DP \\
\hline
\end{tabular}

Horas

\begin{tabular}{llllllllll}
6 & 1,476 & 1,505 & 1,505 & 1,765 & 1,664 & 1,708 & 1,603 & 0,123 \\
12 & 0,763 & 0,794 & 0,803 & 0,958 & 0,877 & 0,900 & 0,849 & 0,074 \\
18 & 0,446 & 0,463 & 0,437 & 0,550 & 0,509 & 0,490 & 0,482 & 0,042 \\
24 & 0,428 & 0,382 & 0,360 & 0,466 & 0,395 & 0,398 & 0,404 & 0,037 \\
\hline
\end{tabular}


Tabela XX- Valores da quantidade de flúor liberado no período de 7 dias pelo XR Ionomer (em $\left.\mu \mathrm{g} \quad \mathrm{F}^{-} / \mathrm{mm}^{2}\right)$.

\begin{tabular}{lllllllll}
\hline Espécimes & 1 & 2 & 3 & 4 & 5 & 6 & Média & DP
\end{tabular}

Dias

$\begin{array}{lllllllllll}1 & 3,690 & 3,545 & 2,923 & 2,547 & 2,923 & 2,692 & 3,053 & 0,462 \\ 2 & 0,829 & 0,980 & 0,854 & 0,754 & 0,912 & 0,819 & 0,858 & 0,078 \\ 3 & 0,614 & 0,642 & 0,586 & 0,509 & 0,595 & 0,544 & 0,581 & 0,048 \\ 4 & 0,428 & 0,502 & 0,449 & 0,388 & 0,469 & 0,462 & 0,449 & 0,038 \\ 5 & 0,376 & 0,451 & 0,428 & 0,339 & 0,409 & 0,318 & 0,386 & 0,051 \\ 6 & 0,321 & 0,365 & 0,321 & 0,292 & 0,340 & 0,301 & 0,323 & 0,026 \\ 7 & 0,292 & 0,334 & 0,304 & 0,263 & 0,304 & 0,286 & 0,297 & 0,023\end{array}$

Tabela XXI- Valores da quantidade de flúor liberado no período de 28 dias pelo XR Ionomer (em $\left.\mu \mathrm{g} \quad \mathrm{F}^{-} / \mathrm{mm}^{2}\right)$.

\begin{tabular}{lllllllll}
\hline Espécimes & 1 & 2 & 3 & 4 & 5 & 6 & Média & DP \\
\hline
\end{tabular}

Dias

$\begin{array}{lllllllll}7 & 5,253 & 5,875 & 5,702 & 6,266 & 5,572 & 5,572 & 5,706 & 0,341 \\ 14 & 1,679 & 1,997 & 1,809 & 1,765 & 1,664 & 1,809 & 1,787 & 0,120 \\ 21 & 1,476 & 1,621 & 1,425 & 1,548 & 1,271 & 1,407 & 1,458 & 0,121 \\ 28 & 1,476 & 1,534 & 1,328 & 1,476 & 1,242 & 1,383 & 1,406 & 0,109\end{array}$


Tabela XXII- Valores da quantidade de flúor liberado no período de 24 horas pelo zionomer pó/ líquido (em $\left.\mu \mathrm{g} \mathrm{F}^{-} / \mathrm{mm}^{2}\right)$.

\begin{tabular}{lllllllll}
\hline Espécimes & 1 & 2 & 3 & 4 & 5 & 6 & Média & DP
\end{tabular}

Horas

$\begin{array}{llllllllll}6 & 0,020 & 0,028 & 0,019 & 0,021 & 0,017 & 0,019 & 0,020 & 0,003 \\ 12 & 0,010 & 0,012 & 0,010 & 0,009 & 0,008 & 0,008 & 0,009 & 0,001 \\ 18 & 0,008 & 0,008 & 0,006 & 0,006 & 0,006 & 0,006 & 0,006 & 0,001 \\ 24 & 0,007 & 0,008 & 0,005 & 0,006 & 0,005 & 0,006 & 0,006 & 0,001\end{array}$

Tabela XXII- Valores da quantidade de flúor liberado no período de 7 dias pelo zionomer pó/líquido (em $\mu \mathrm{g} \quad \mathrm{F}^{-} / \mathrm{mm}^{2}$ ).

\begin{tabular}{lllllllll}
\hline Espécimes & 1 & 2 & 3 & 4 & 5 & 6 & Média & DP \\
\hline
\end{tabular}

Dias

$\begin{array}{lllllllllll}1 & 0,031 & 0,042 & 0,032 & 0,030 & 0,022 & 0,026 & 0,030 & 0,006 \\ 2 & 0,020 & 0,027 & 0,017 & 0,019 & 0,014 & 0,015 & 0,018 & 0,004 \\ 3 & 0,012 & 0,017 & 0,013 & 0,020 & 0,012 & 0,012 & 0,014 & 0,003 \\ 4 & 0,011 & 0,014 & 0,009 & 0,011 & 0,008 & 0,009 & 0,010 & 0,002 \\ 5 & 0,007 & 0,010 & 0,007 & 0,008 & 0,006 & 0,007 & 0,007 & 0,001 \\ 6 & 0,006 & 0,008 & 0,006 & 0,007 & 0,006 & 0,006 & 0,006 & 0,001 \\ 7 & 0,006 & 0,008 & 0,007 & 0,007 & 0,006 & 0,006 & 0,006 & 0,001\end{array}$


Tabela XXIV- Valores da quantidade de flúor liberado no período de 28 dias pelo zionomer pó/líquido (em $\left.\mu \mathrm{g} \mathrm{F}^{-} / \mathrm{mm}^{2}\right)$.

\begin{tabular}{lllllllll}
\hline Espécimes & 1 & 2 & 3 & 4 & 5 & 6 & Média & DP \\
\hline
\end{tabular}

Dias

$7 \quad 0,0510,0520,0500,0690,050 \quad 0,0510,0530,007$

$140,0360,0410,0380,0470,027 \quad 0,0380,0370,006$

$210,0290,0360,0300,0290,0200,0290,0280,005$

$280,0300,0320,0370,0330,0240,0270,0300,004$ 